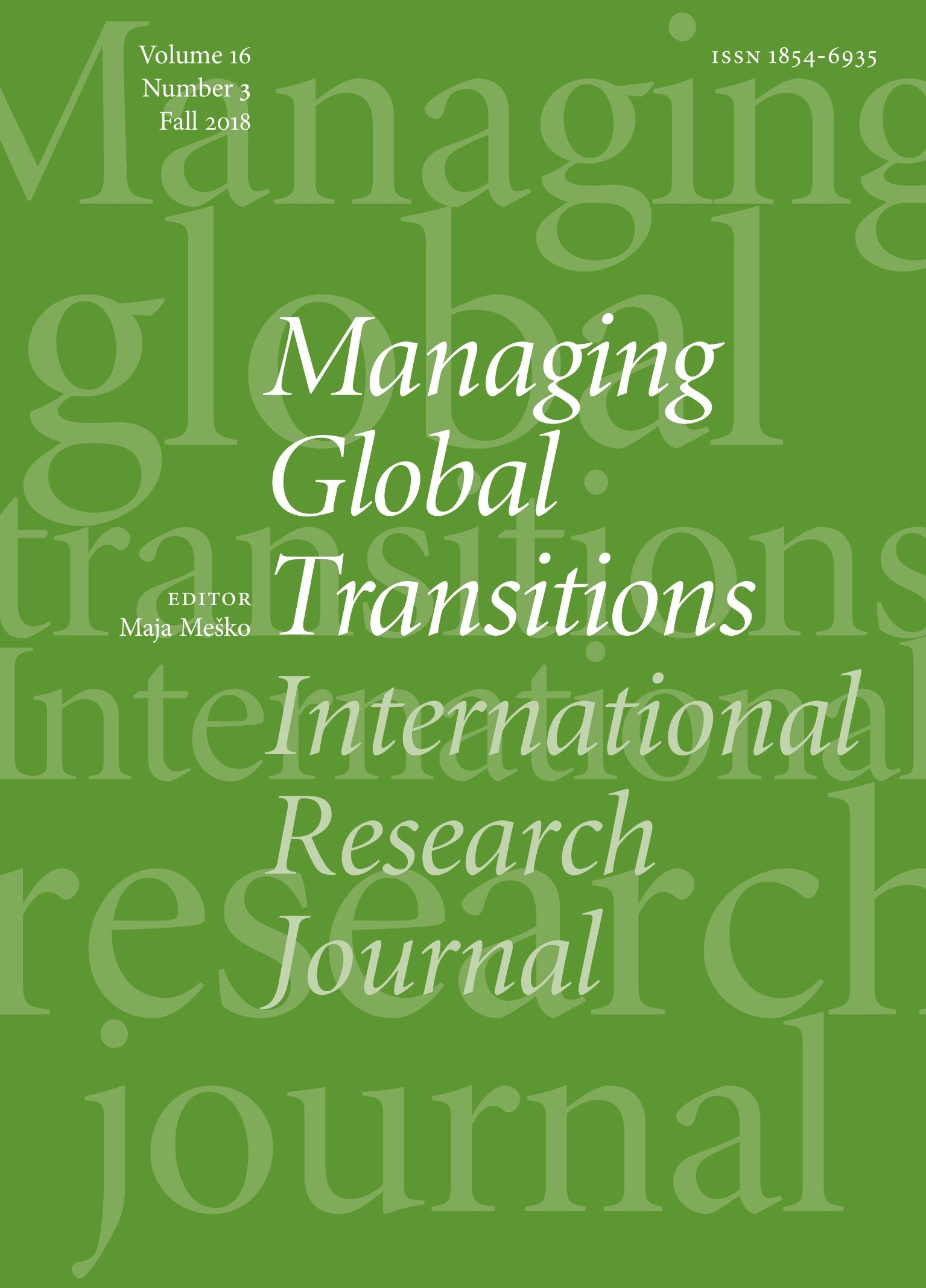




\section{Managing Global Transitions International Research Journal}

ISSN $1854-6935 \cdot$ www.mgt.fm-kp.si

EDITOR

Maja Meško, University of Primorska, Slovenia,maja.mesko@fm-kp.si

ASSOCIATE EDITORS

Andrej Bertoncelj, University of Primorska, Slovenia, andrej.bertoncelj@fm-kp.si

Gandolfo Dominici, University of Palermo, Italy,gandolfo.dominici@libero.it

Alexander Laszlo, Buenos Aires Institute of Technology, Argentina, alaszlo@itba.edu.ar

MANAGING AND PRODUCTION EDITOR

Alen Ježovnik, University of Primorska Press, Slovenia,alen.jezovnik@upr.si

EDITORIAL BOARD

Jani Bekő, Univerza v Mariboru, Slovenia, jani.beko@uni-mb.si

Heri Bezić, University of Rijeka, Croatia, bezic@efri.hr

Guido Bortoluzzi, University of Trieste, Italy, guido.bortoluzzi@deams.units.it

David L. Deeds, University of St. Thomas, usA,david.deeds@gmail.com

Evan Douglas, Griffith Universitiy, Australia, e.douglas@griffith.edu.au

Dean Fantazzini, Moscow School of Economics, Russia, fantazzini@mse-msu.ru

Henryk Gurgul, A GH University of Science and Technology, Poland, henryk.gurgul@gmail.com

András Inotai, Hungarian Academy of Sciences, Hungary, inotai.andras@krtk.mta.hu

Felicetta Iovino, University of Sannio, Italy, fiovino@unisannio.it

Hun Joon Park, Yonsei University, South Korea,hjpark@yonsei.ac.kr

Renata Karkowska, University of Warsaw, Poland,rkarkowska@wz.uw.edu.pl

Tanja Kosi Antolič, Institute of Macroeconomic Analysis and Development, Slovenia, tanja.kosi-antolic@gov.si
Leonard H. Lynn, Case Western Reserve University, UsA, leonard.lynn@case.edu Monty Lynn, Abilene Christian University, USA, monty.lynn@coba.acu.edu

Massimiliano Marzo, University of Bologna, Italy,massimiliano.marzo@unibo.it

Judita Peterlin, University of Ljubljana, Slovenia, judita.peterlin@ef.uni-lj.si

Mirjana Pejić Bach, University of Zagreb, Croatia,mpejic@efzg.hr

Sanja Peković, University of Crna Gora, Montenegro,psanja@ac.me

Sandra Penger, University of Ljubljana, Slovenia,sandra.penger@ef.uni-lj.si

Zdenko Prohaska, University of Rijeka, Croatia, zdenko.prohaska@efri.hr

José Solana Ibánez, Technical University of Cartagena, Spain, jose.solana@cud.upct.es

Marinko Škare, University of Pula, Croatia, mskare@unipu.hr

Nada Trunk Širca, International School of Social and Business Studies, Slovenia, trunk.nada@gmail.com

Šárka Velčovská, Technical University of Ostrava, Czech Republic, sarka.velcovska@vsb.cz

Manfred Weiss, Johann Wolfgang Goethe University, Germany, m.weiss@jur.uni-frankfurt.de

INDEXING AND ABSTRACTING

Managing Global Transitions is indexed/ listed in the International Bibliography of the Social Sciences, EconLit, I z Z Online, DoAJ, Erih Plus, EconPapers, Cabell's, EBsCO, and ProQuest.

SUPPORTED BY

Slovenian Research Agency.

Revija Managing Global Transitions je namenjena mednarodni znanstveni javnosti; izhaja $v$ angleščini s povzetki $v$ slovenščini. Izid revije je finančno podprla Javna agencija za raziskovalno dejavnost Republike Slovenije iz sredstev državnega proračuna iz naslova razpisa za sofinanciranje izdajanja domačih znanstvenih periodičnih publikacij. 


\section{Managing Global Transitions International Research Journal}

VOLUME $16 \cdot$ NUMBER 3 FALL $2018 \cdot$ ISSN 1854-6935

195 Is Health Care Necessity or Luxury Good? Panel Data Analysis on the Example of the SEenn Countries Saša Obradović and Nemanja Lojanica

215 Discovering Chinese Product Strategies on Stimulating Attitude and Intention: Involvement of Innovation, Country-of-Origin and Knowledge Ramadania, Rianti Ardana Reswari, and Endang Dhamayantie

235 Macroeconomic Implications of Exchange Rate Depreciation: The Nigerian Experience Ekundayo P. Mesagan, Olorunfemi Y. Alimi, and Ismaila A. Yusuf

259 Different Ways of Environmental Issue Management by Active Citizens: Case Studies from Hungary Adrienn Reisinger and Katalin Bándy

279 Modern Trends in Chinese Foreign Direct Investment in Africa: An oli Approach

Henri Bezuidenhout and Ewert P. J. Kleynhans

301 Abstracts in Slovene 
AIMS AND SCOPE

Managing Global Transitions (MGT) is a quarterly, scholarly journal that covers diverse aspects of transitions and welcomes research on change and innovation in increasingly digitalized and networked economic environments, from a societal, organizational, and technological perspective. MGT fosters the exchange of ideas, experience and knowledge among developed and developing countries with different cultural, organizational and technological traditions. MGT invites conceptual, theorydevelopment, empirical and review papers and case-based studies advancing the field of transitions in societies, organizations and technologies.

\section{TOPICS COVERED}

\section{Transitions in Societies}

- Geo-political transitions, transition experiments, pathways and mechanisms

- Social, demographic, cross-cultural, ethical, geo-political and security aspects of transitions

- Social change, prosperity, wellbeing, happiness

- Policy making, government regulation, social responsibility

- Knowledge-based society and world futures

- New and emerging metrics for measuring, assessing and evaluating societal transitions

\section{Transitions in Organizations}

- Organizational analysis and design, modeling, developments and changes in organizational learning and behavior

- International strategy and strategic alliances, networked businesses and operations

- Entrepreneurship and leadership, decision making

- Knowledge sourcing and innovation management, personal development, education and training, HRM

- Business systems and business models

- Connective intelligence and collective intelligence in organizational behavior
Transitions in Technologies

- Managing technological/organizational change and innovation

- Technology networks, technology transfer benefits and risks, technology acquisition and diffusion

- Smart technologies and development discontinuities, renewable sources and sustainability

- Digitalization, гот, гст, cybernetics, forecasting

- Technological traditions, strategic surprise and response systems

- Studies that promote understanding of the dynamics of socio-technical systems change

- Science and technology policy that fosters transformative advancement

- Modeling technological change in vucA (volatile, uncertain, complex, ambiguous) environments

SUBMISSIONS

The manuscripts should be submitted as e-mail attachment to the editorial office at mgt@fm-kp.si. Detailed guide for authors and publishing ethics statement are available at www.mgt.fm-kp.si.

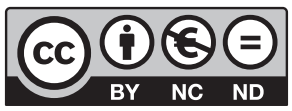

EDITORIAL OFFICE

University of Primorska

Faculty of Management

Cankarjeva 5, 6104 Koper, Slovenia

mgt@fm-kp.si · www.mgt.fm-kp.si

PUBLISHED BY

University of Primorska Press

Titov trg 4, 60oo Koper, Slovenia

zalozba@upr.si·www.hippocampus.si

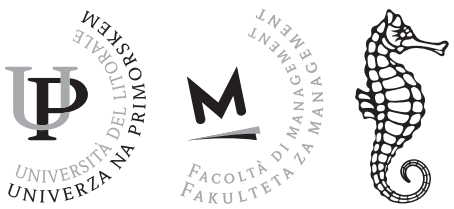




\title{
Is Health Care Necessity or Luxury Good? Panel Data Analysis on the Example of the SEEHN Countries
}

\author{
Saša Obradović \\ University of Kragujevac, Serbia \\ sobradovic@kg.ac.rs \\ Nemanja Lojanica \\ University of Kragujevac, Serbia \\ nlojanica@kg.ac.rs
}

The main goal of this paper is oriented on examining the potential link between economic growth and health expenditure in the South-Eastern European Health Network (SEEHN) countries over the period 1995-2014 by applying panel econometrics. The panel co-integration testing approach and panel VЕсм are used to investigate the long- and short-run causality between the economic growth, health expenditure and life expectancy (trivariate model). The empirical results show that there is a long-run relationship between the observed variables. It was confirmed that health is a luxury good in the long term, while it is a necessity product in the short term. Finally, it should be noted that economic policy in these countries should be directed to the targeted increase in expenditure on health care, in order to increase overall economic activity. Also, the economic policy should be oriented to adequate combination of public and private financing in health care.

Key Words: health expenditure, economic growth, South-Eastern Europe Health Network, panel co-integration, panel VECM

JEL Classification: C23, H51, I1O, I15

https://doi.org/10.26493/1854-6935-16.195-214

\section{Introduction}

Health has been a clear objective since the founding of the United Nations, when the Universal Declaration of Human Rights set striving to achieve 'the highest attainable standard of physical and mental health' (Sachs 2014). In many segments of the world, this goal has not been fully realized. Making progress in the area of health and economic development represents major challenges of modern times. Health issues are very sensitive in every society. Providing good health services in budgetconscious environments, such as South East European countries, presents 
the question of a great importance. According to SE E 2020 Strategy (Regional Cooperation Council 2013), sustainable growth will only become a reality if there is a strong expenditure in human capital, such as health. On the basis of numerous theoretical and empirical studies, which will be mentioned further in this paper, health is seen as a significant factor that has a great positive effect on the economic growth. On the other hand, the growth of economic activities improves the material conditions of life, and thus should have a positive impact on health. In order to promote health, governments of South Eastern Europe countries formed SEEHN (South-Eastern Europe Health Network) forum. Despite notable improvements in health care, SEEHN has identified a lot of weaknesses, such as lack of financial sustainability, demographic ageing, and so on. Modernization of health care policy in the SEEHN countries is one of the prerequisites for further integration process. These are the reasons why the countries of South-Eastern Europe Health Network will be discussed in this analysis. Regarding the foregoing, the main goal of this study is to investigate the relation between health expenditures and economic growth on the sample of SEEHN countries in the period 19952014.

Contribution of the paper is as follows. Firstly, the current study for the first time has used the panel data covering the SEEHN countries for revealing the nature of relation between health expenditure and economic growth. Secondly, this study employs Pesaran second generation panel unit root test to determine the order of the integration of panel series. Thirdly, we use simultaneously Pedroni and newly developed Westerlund co-integration analysis to confirm the test results. The findings of this study may also serve as a form of tutorial to the other small open economies with similar health challenges. Also, to the best of the author's knowledge, there is no study which tested the empirical regularity on the long-term relationship between health care and economic growth on the sample of SEEHN countries. This article is organized in five sections: apart from the introductory remarks, the second section provides recent literature overview of links between health expenditures and economic growth. In the third section, we introduce the data and starting from the model, in which it is assumed that economic growth and health expenditure are two-way related, the basic econometric tests that will be used in the work are shown. In the fourth section, the results of the research and discussion are presented. Finally, the fifth section presents the concluding remarks and policy implications. 


\section{Literature Review}

Pioneer research into the relation between the economic growth and health expenditure is present in the studies of Kleiman (1974) and Newhouse (1977). Specifically, they found a positive relation between health variables and economic growth. Theoretically speaking, it can be said that higher output means more money, which among other things means greater expenditure in health care (Fuchs 1998). Because of the significant expenditure in healthcare during the last four decades, Elk et al. (2010) pointed out that it is important to get more insights about the role of health as a determinant of growth. According to Lucas (1988), health care can be seen as the engine of growth, since the expenditure in health care involves the investment in human capital, which provides workers with better health, higher productivity and ultimately, a higher level of output (Barro 1991). These statements about the potential relations between health and economic growth are clearly related to a positive relationship between these two variables. Conversely, it is important to point out the research conducted by Acemoglu and Johnson (2006), which showed that an increase in the life expectancy leads rather to a larger increase in the total population than in the economic growth, which ultimately reduces output per capita. So, here we have a negative relation between the variables. However, Acemoglu and Johnson (2006) stated certain limitations of this result, among which stands out the fact that the results relating to a period of more than 60 years may not be applicable in today's environment. Ye and Zhang (2018) highlighted that in order to improve the quality of national health, life quality and happiness, OECD countries should actively look to optimize policy related to health care expenditure, such as by enhancing the efficiency of health costs to promote sustainable economic development. Wang and Lee (2018) showed that economic growth stimulates health expenditure growth, but health expenditure growth reduces economic growth. The above-mentioned theoretical attitudes found their place in empirical studies too, on the basis of which it is possible to distinguish four key types of causal relations between health expenditure and economic growth. Each of these relations carries with itself certain policy implications. Therefore, in accordance with the results of previous studies, the causal relations between these two variables are categorized into the following groups:

- Growth hypothesis implies unidirectional causality from health expenditure to economic growth. The implication of this result is eco- 
nomic growth dependence from the investments in health expenditure. Among others, the results in accordance with this hypothesis are obtained in the researches of Devlin and Hansen (2001), Bloom and Canning (2008), Bukenya (2009), Magazzino (2011), Majdi (2012). Also, Erdil and Yetkiner (2009) show that one-way causality runs from health to income in high-income countries.

- Growth detriment implies unidirectional causality from the economic growth to health expenditure. This direction of causality can also be called the 'income view.' With this result, the economic growth is a key determinant of growth in health expenditure. This hypothesis is in accordance with the empirical results of Hartwig (2010), Chen et al. (2013), Ozturk and Topcu (2014), Khan et al. (2016), Halici-Tuluce, Dogan, and Dumrul (2016).

- Feedback hypothesis implies a two-way causality between health expenditure and economic growth. The increased investment in health expenditure leads to creating a healthier environment, increased productivity and higher output. On the other hand, a higher level of output will involve a higher demand for the health care system. The implications of this hypothesis are related to the fact that excessive control of costs in the health system may limit the economic activity. The empirical results in accordance with this hypothesis can be found in the studies of Pradhan (2010), Tang (2011), Chen, Clarke, and Roy (2014).

- Neutrality hypothesis implies the absence of a causal relation between these two variables. Newhouse (1977) gives the explanation of this result, noting that in this case, the formation of the appropriate health care policy should not depend on the economic activity. This result was confirmed in the studies of Cetin and Ecevit (2010), Balaji (2011).

In contrast to afore-mentioned findings, Chen (2015) pointed out that none of these four types of causality are valid for US A over the entire period of 1934-2010. It is evident that in the empirical studies that have examined the relation between health expenditure and economic growth, ambiguity of the results exists. The results are not consistent. The reason should be sought in the fact that during the study of the connection between the variables, several approaches were used while modelling this connection. Gerdtham and Lothgren (2000) distinguish the following econometric approaches, which are most commonly used: cross-section 
bivariate regressions, cross-sectional multivariate regressions, panel data models and cointegration analysis. By applying the panel cointegration analysis, Gerdtham and Lothgren (2002) indicate that health expenditure and GDP are cointegrated around linear trends. The panel data were also used in the following studies: Hitiris and Posnett (1992), Barros (1998), Roberts (1999), Baltagi and Moscone (2010).

With the implementation of the appropriate economic policy, it is important to calculate the income elasticity for health care as well. This is very important for the financing model itself as well as for the health care resource distribution. If the income elasticity of health care is greater than one, then health expenditures will be considered as a luxury good. This implies that the health expenditures increase faster than income. Proponents of the idea that healthcare is a luxury good feel that it should be treated like any other good and should be left to the functioning of market forces. On the other hand, health care expenditures could be a necessity good. This suggests income increases faster than health expenditures. Proponents of the idea that this good is necessary for life, support the idea of the government intervention in the healthcare sector of a country (Di Matteo 2003).

In previous studies, as well as in the case of establishing causality between the variables, there is no agreement between the authors whether the healthcare is a luxury or a necessity good. Blazquez-Fernandez, Cantarero, and Perez (2014) revealed increasing income elasticity over time along with huge heterogeneity across OECD countries. Chen, Lin, and Chang (2009) indicate that health care is necessity for countries with per capita income lower than $\$ 1920$ per year and is luxury for other countries. According to Kleiman (1974), Newhouse (1977), Leu (1986), Gerdtham et al. (1992), Schieber and Maeda (1999), Getzen (2000), Musgrove, Zeramdini, and Carrin (2002), Murthy and Okunade (2009), Hassan et al. (2014), Khan and Mahumud (2015), healthcare is a luxury good, while Freeman (2003), Sen (2005), Yu and Chu (2007), Baltagi and Moscone (2010), Narayan, Naeayan, and Smith (2011), Farag et al. (2012), Yavuz, Yilanci, and Ozturk (2013), Khan et al. (2016), Pattnayak and Chadha (2016), Abdullah, Siddiqua, and Huque (2017), consider it as a necessity good.

\section{Data and Methodology}

In accordance with the primary objective of this study, the following hypotheses will be tested: 
$\mathrm{H} 1$ There is a long-run relationship between the economic growth and health expenditures.

$\mathrm{H} 2$ Health expenditures generate the economic growth.

$\mathrm{H} 3$ The rate of economic activity largely determines health expenditures.

In that sense, three variables will be used: Gross domestic product (GDP), health expenditure (HE) and life expectancy (LE). This study uses gross domestic product and health expenditure as variables of interest, while life expectancy is used as a control variable. To test the potential link between the variables, we used a sample of the SEEHN countries (Albania, Bulgaria, Bosnia and Herzegovina, Croatia, FY R Macedonia, Moldova and Romania) and panel data set from 1995 to 2014. Information on the movement of the variables is taken from the World Bank website (http://www.worldbank.org), that is, World Development Indicators. Economic growth is expressed by the gross domestic product (GDP), which is measured by the purchasing power parity in the international prices (constant $2011 \$$ ), while for the healthcare expenditure, indicator Health expenditure ( $\mathrm{HE}$ ) is used as well, measured by the purchasing power parity in the international prices (constant 2011\$). Life expectancy is measured at birth, total (years). The values of GDP and $\mathrm{HE}$ variables are displayed per capita, while for statistical reasons, the values of all indicators are shown in logarithmic form (ln). The total number of observations is 140 ( 20 time periods in 7 countries). Table 1 shows the descriptive statistics in these countries during the mentioned period of time. The South Eastern Europe countries differ in their overall level of the economic development. According to the World Bank country classification (see http://www.worldbank.org), Moldova belongs to lower-middle income economy, Albania, Bosnia and Herzegovina, Bulgaria, FY R Macedonia and Romania are upper-middle income countries, while Croatia is high-income economy. Also, the highest level of health expenditure is realized in Croatia, and the lowest in Moldova. Moreover, the life expectancy in Moldova is lower than in all other observed countries. Visually speaking, $\mathrm{HE}$ is in line with the level of GDP per capita.

Numerous theoretical assumptions listed above, emphasize the importance of investing in health care to increase the economic growth, and the impact of total output on variations in the health care expenditure. Expenditure in health care should enable the absence of chronic diseases and should increase labour productivity, by which the economic prosperity can be affected, as well. A higher level of the economic growth implies 
TABLE 1 Descriptive Statistics in the SeEhn Countries (1995-2014)

\begin{tabular}{|c|c|c|c|c|}
\hline Category & Country & Mean & Std. Dev & $\mathrm{JB}^{*}$ \\
\hline \multirow[t]{7}{*}{ GDP per capita } & Albania & 6977.756 & 2213.898 & 1.726 \\
\hline & Bulgaria & 12298.23 & 3116.458 & 2.406 \\
\hline & B \& $\mathrm{H}$ & 7354.182 & 2265.241 & 2.652 \\
\hline & Croatia & 17995.38 & 2846.805 & 1.813 \\
\hline & FYR Macedonia & 9707.933 & 1567.024 & 2.096 \\
\hline & Moldova & 3249.976 & 800.479 & 1.568 \\
\hline & Romania & 14166.81 & 3476.459 & 2.312 \\
\hline \multirow[t]{7}{*}{ HE per capita } & Albania & 389.335 & 135.739 & 1.884 \\
\hline & Bulgaria & 721.440 & 364.756 & 1.303 \\
\hline & $\mathrm{B} \& \mathrm{H}$ & 562.655 & 276.251 & 1.679 \\
\hline & Croatia & 1137.250 & 427.876 & 2.233 \\
\hline & FYR Macedonia & 636.351 & 132.717 & 1.350 \\
\hline & Moldova & 290.697 & 148.864 & 2.340 \\
\hline & Romania & 568.916 & 335.862 & 2.190 \\
\hline \multirow[t]{7}{*}{ LE } & Albania & 75.491 & 1.783 & 1.694 \\
\hline & Bulgaria & 72.559 & 1.386 & 0.973 \\
\hline & $\mathrm{B} \& \mathrm{H}$ & 74.733 & 1.352 & 2.71 \\
\hline & Croatia & 74.879 & 1.809 & 1.856 \\
\hline & FYR Macedonia & 73.879 & 0.981 & 1.141 \\
\hline & Moldova & 68.218 & 1.637 & 2.601 \\
\hline & Romania & 71.951 & 1.902 & 0.867 \\
\hline
\end{tabular}

NOTES ${ }^{\star}$ Jarque and Bera (1980).

a higher income, too, and thus the expenditures in health care should be increased. On this basis, it could be said that there is a positive twoway causality between these variables. Accordingly, we assume that the connection between the economic growth and health expenditure can be summarized as follows:

$$
\begin{aligned}
\ln (\mathrm{GDP})_{i t} & =\theta_{i}+\beta_{1} \ln (\mathrm{HE})_{i t}+\beta_{2} \ln (\mathrm{LE})_{i t}+\varepsilon_{1, i t}, \\
\ln (\mathrm{HE})_{i t} & =\gamma_{i}+\alpha_{1} \ln (\mathrm{GDP})_{i t}+\alpha_{2} \ln (\mathrm{LE})_{i t}+\varepsilon_{2, i t},
\end{aligned}
$$

where $i=1,2, \ldots, N$ is the index of the country, $t=1,2, \ldots, T$ is the time index, $\beta_{1}, \beta_{2}, \alpha_{1}$, and $\alpha_{2}$ indicate the long-term effects of the independent on the dependent variable, and $\theta_{i}$ and $\gamma_{i}$ are country-specific fixed ef- 
TABLE 2 Cross Section Dependency Test

но: No cross-section dependence in residuals

Probability

Breusch-Pagan LM test

0.0000

fects, while $\varepsilon_{1, i t}$ and $\varepsilon_{2, i t}$ are error terms. Taking into account that potential existence of common shocks among selected countries could result in creating contemporaneous correlation, it is very important to specify cross-sectional dependencies. Breusch and Pagan (1980) LM test for cross-equation correlation is used for testing cross-sectional dependence, because the number of time periods $(T)$ is larger than cross-sectional units $(N)$. The result of the cross-sectional independence test is reported in table 2. Probability value is below the 0.05 , the effect is statistically significant. The Breusch-Pagan LM test strongly rejects the null hypothesis of no cross-sectional dependence. In that sense, the second generation panel unit root test should be used. The second generation tests imply that there is a correlation between individual units of panel. Since existence of the correlation between cross-sectional data is already shown, this study applies the test developed by Pesaran (2007).

In order to determine long-term relationship, Pedroni (1999) test of cointegration in a panel has been used here. The null hypothesis that variables are not co-integrated is tested against the alternative hypothesis that variables in a panel are co-integrated. The Pedroni panel co-integration test can be presented in the following form:

$$
y_{i t}=\theta_{i}+\rho_{i} t+\beta_{1 i} x_{1 i t}+\cdots+\beta_{M i} x_{M i t}+\varepsilon_{i t},
$$

where $M$ is the number of regressors, $\beta_{M}$ is the coefficient, $\theta_{i}$ and $\rho_{i}$ represents deterministic components. Pedroni defines seven types of such tests. The first four tests (within groups) are based on the separate evaluations of models for individual units. By grouping the obtained results, the variable dimension is formed, according to which co-integration is evaluated. The second group of tests (between the groups) implies that evaluation is being performed for each separate unit, and then relevant value of test statistics is formed according to the mean value of Dickey Fuller statistics for all $i$ units. The next test that will be used to examine the cointegration is Westerlund (2007). Based on the error correction model (ЕСM), this test implies four panel cointegration tests (Ga, Gt, Pa and $\mathrm{Pt}$ ). These four test statistics are normally distributed and based on structural dynamics rather than residuals dynamics. Also, they do not include any common factor restriction, and these tests are general enough 
to be robust against heterogeneity and cross section dependence. Westerlund (2007) cointegration test is appropriate for small-sample and it is possible to get reliable results. Also, this test has a power relative to other popular residual-based panel cointegration tests. The null hypothesis is tested by determining whether error correction is present for individual panel members and for the panel as a whole. If the null of no cointegration is rejected, then co-integration between the variables exists. Taking into account that all the variables are integrated of order 1 , cointegration test assumes the following data generating process:

$$
\begin{aligned}
\Delta y_{i t}= & \delta_{i}^{\prime} d_{t}+\alpha_{i} y_{i(t-1)}+\pi_{i}^{\prime} x_{i(t-1)} \\
& +\sum_{j=1}^{m_{i}} \alpha_{i j} \Delta y_{i(t-j)}+\sum_{j=0}^{m_{i}} \phi_{i j} \Delta x_{i(t-j)}+\omega_{i t},
\end{aligned}
$$

where $d_{t}=(1-t)^{\prime}$ holds the deterministic components, $\delta_{i}^{\prime}$ represents the associated vector of parameters, while $\alpha_{i}$ is the speed adjustment term. If $\alpha_{i}<1$ then cointegration exists, while if $\alpha_{i}=1$, there is no cointegration. After testing cointegration, evaluation of the long-run parameters is carried out with the help of the panel Dynamic Ordinary Least Square (DOLS) developed by Pedroni (2001). This approach allows greater flexibility in the case of presence of heterogeneous cointegration vectors. Kao and Chiang (2000) have emphasized that DoLs is less biased in respect to F MOLS while Pedroni (2000) has indicated that there is a lower degree of distortion in Dols than in F MOLs. Dynamic ols in the panel model can be shown in the following form:

$$
y_{i t}=\alpha_{i}+\beta x_{i t}+\sum_{j=-p_{i}}^{p_{i}} \phi_{i j} \Delta x_{i t-j}+\varepsilon_{i t},
$$

where $\phi_{i j}$ represents the coefficients of the lead and lag differences, which accounts for possible serial correlation and endogeneity of the regressor(s), thus yielding unbiased estimates, while $\pm p_{i}$ is the number of lags and leads. DoLs generates unbiased estimates for cointegrating variables, even with endogenous regressors, which is very important feature of this procedure. To determine the direction of long-run causality and to examine short-run dynamics between the variables, the panel $\mathrm{VECM}$ model is used, that is, the residual from DoLs long-term relation will be included:

$$
e c_{i t}=y_{i t}-\left[\widehat{\alpha}_{i}+\widehat{\beta}_{i} x_{i t}\right]
$$


TABLE 3 Results of the Panel Unit Root Test

\begin{tabular}{|c|c|c|c|c|c|c|}
\hline \multirow[t]{3}{*}{ Series } & \multicolumn{6}{|c|}{ PESCADF (constant \& trend) } \\
\hline & \multicolumn{3}{|c|}{ Levels } & \multicolumn{3}{|c|}{ First difference } \\
\hline & t-bar test & cv5 & cv1 & t-bar test & cv5 & cV1 \\
\hline $\ln (\mathrm{GDP})_{i t}$ & -2.716 & -2.880 & -3.150 & -3.912 & -2.880 & -3.150 \\
\hline $\ln (\mathrm{HE})_{i t}$ & -2.477 & -2.880 & -3.150 & -3.753 & -2.880 & -3.150 \\
\hline $\ln (\mathrm{LE})_{i t}$ & -1.856 & -2.880 & -3.150 & -4.497 & -2.880 & -3.150 \\
\hline
\end{tabular}

NOTES Cv5 and cv1 are critical value at 5 and $1 \%$, respectively.

and error correction terms (ЕСT) is included in a simple panel VECM model as follows:

$$
\left[\begin{array}{c}
\Delta y_{i t} \\
\Delta x_{i t}
\end{array}\right]=\left[\begin{array}{c}
c_{1 i} \\
c_{2 i}
\end{array}\right]+\sum_{j=1}^{k} \Gamma_{j=1}\left[\begin{array}{c}
\Delta y_{i t-j} \\
\Delta x_{i t-j}
\end{array}\right]+\left[\begin{array}{l}
\alpha_{1} \\
\alpha_{2}
\end{array}\right] e c_{i t-1}+\left[\begin{array}{c}
\varepsilon_{1 i t} \\
\varepsilon_{2 i t}
\end{array}\right],
$$

where $c_{1 i}$ and $c_{2 i}$ are fixed effects, $e c_{i t-1}$ represents an error or deviation from the equilibrium, while $\alpha_{1}$ and $\alpha_{2}$ represent the adjustment coefficients and show how dependent and independent variables react to deviations from the equilibrium relationship. Statistically significant result for ЕС T involves long-run causality, as well as the long-term endogeneity of the variables (Hall and Milne 1994). To determine the short-term causality, the coefficients standing with the independent variables will be used, noting that the independent variables will be displayed with an appropriate lag length. Also, both variables will be converted to a first difference, due to the assumption that they are stationary after converting into the first difference.

\section{Empirical Results}

The table 3 presents the results of the stationarity for the variables. Following the stationarity test (Pesaran 2007), the null hypothesis about the existence of unit root in all the variables in level cannot be rejected. After the variable conversion into the first difference, they became stationary (the null hypothesis about the unit root is rejected) and the obtained result is statistically significant.

The results of Pedroni panel cointegration test based on within dimension and between dimension PP and ADF statistic are reported in the table 4. In the table, $\ln (\mathrm{GDP})_{i t}$ is presented as a dependent variable. In such case, we consider $\ln (\mathrm{HE})_{i t}$ and $\ln (\mathrm{LE})_{i t}$ as independent variables. According to Pedroni (1999) test, the null hypothesis of no cointegration is 
TABLE 4 Panel Co-Integration Tests, Series $\ln (\mathrm{GDP})_{i t}, \ln (\mathrm{HE})_{i t} \ln (\mathrm{LE})_{i t}$

\begin{tabular}{llrrrr}
\hline (1) & Test statistics & Statistic & Probability & Weighted stat. & Probability \\
\hline (a) & Panel PP-statistics & -2.140 & $0.016^{* *}$ & -2.058 & $0.019^{\star *}$ \\
& Panel ADF-statistics & -3.480 & $0.000^{*}$ & -3.018 & $0.001^{*}$ \\
\hline (b) & Group PP-statistics & -2.104 & $0.018^{* *}$ & - & - \\
& Group ADF-statistics & -3.181 & $0.000^{*}$ & - & - \\
\hline (2) & Test statistics & Value & Z-value & Probability & \\
\hline & Gt & -2.660 & -3.227 & $0.001^{*}$ & \\
& Ga & -6.359 & -0.259 & 0.398 & \\
& Pt & -4.279 & -1.354 & $0.088^{\star * *}$ & \\
& Pa & -6.214 & -2.005 & $0.023^{* *}$ & \\
\hline
\end{tabular}

NOtes (1) Pedroni (1999) cointegration test, null hypothesis: no cointegration; (2) Westerlund (2007) ECM cointegration test, null hypothesis: no cointegration; (a) within dimension; (b) between dimension. ${ }^{\star},{ }^{* *}$ and ${ }^{\star * \star}$ refer to $1 \%, 5 \%$ and $10 \%$ of the test significance.

rejected by the panel PP statistic, panel ADF statistic, group PP statistic and group ADF statistic. In line with the statistically significant results, it can be said that there exists cointegration between variables. Also, the results of Pedroni cointegration test, when $\ln (\mathrm{HE})_{i t}$ is seen as a dependent variable, are reported in the table 5 . We consider $\ln (\mathrm{GDP})_{i t}$ and $\ln (\mathrm{LE})_{i t}$ as independent variables. The same outcome, in terms of the statistical significance of the results, as in the first case, points to the existence of the cointegration between the variables. To check the robustness of Pedorni's cointegration results, we also employ Westerlund (2007) for both cases, and the results are shown in the table 4 and table 5. For testing the cointegration when $\ln (\mathrm{GDP})_{i t}$ is considered as a dependent variable, the null hypothesis of no cointegration was rejected by 3 (out of 4 ) statistics of Westerlund (2007). In the specification when $\ln (\mathrm{HE})_{i t}$ is considered as a dependent variable, 3 among 4 statistics of Westerlund (2007) were found to be statistically significant.

For assessment of the long-run effects of economic growth on health expenditures and vice versa, Dols method is used. As in the case of cointegration testing between the variables, two cases are also examined here. Table 6 contains the estimation results of long-run relationship among the economic growth, health expenditure and life expectancy. Firstly, the economic growth is considered as a dependent variable. It is evident that there is a positive and statistically significant relationship between the 
TABLE 5 Panel Co-Integration Tests, Series $\ln (\mathrm{HE})_{i t}, \ln (\mathrm{GDP})_{i t}, \ln (\mathrm{LE})_{i t}$

\begin{tabular}{llrrrr}
\hline (1) & Test statistics & Statistic & Probability & Weighted stat. & Probability \\
\hline (a) & Panel PP-statistics & -1.822 & $0.034^{* *}$ & -2.369 & $0.009^{*}$ \\
& Panel ADF-statistics & -2.673 & $0.004^{*}$ & -3.035 & $0.001^{*}$ \\
\hline (b) & Group PP-statistics & -2.575 & $0.005^{*}$ & - & - \\
& Group ADF-statistics & -3.319 & $0.000^{*}$ & - & - \\
\hline (2) & Test statistics & Value & Z-value & Probability & \\
\hline & Gt & -2.498 & -2.818 & $0.002^{*}$ & \\
& Ga & -5.118 & 0.342 & 0.634 & \\
& Pt & -6.031 & -2.673 & $0.004^{*}$ & \\
Pa & -5.544 & -1.644 & $0.050^{* *}$ & \\
\hline
\end{tabular}

NOtes (1) Pedroni (1999) cointegration test, null hypothesis: no cointegration; (2) Westerlund (2007) ECM cointegration test, null hypothesis: no cointegration; (a) within dimension; (b) between dimension. ${ }^{*},{ }^{* *}$ and ${ }^{* *}$ refer to $1 \%, 5 \%$ and $10 \%$ of the test significance.

economic growth and health expenditure. The income elasticity coefficient, in respect to health expenditure, varies from 0.371 to 0.498 . In fact, this result can be justified by the observation that the economic growth of the SEEHN countries depends largely on the investments in health care (human capital). Furthermore, in case when the economic growth is a dependent variable, the coefficient which stands for life expectancy is 1.863 which means that health improvement has a significant influence on the economic growth. This result is in agreement with theoretical views that increased investments in healthcare prolong the anticipated life expectancy of people, which ultimately affects the economic growth.

And in the second case, when the health expenditure is a dependent variable, the positive long-run statistically significant relation between the health expenditures and economic growth is also evident. This result can be explained by the fact that with the accomplishment of the economic activity in the SEEHN countries, more funds will be available to public and private institutions, which will enable the increase of the share of resources that is allocated to the health sector. In the present case, the elasticity coefficient of health expenditure with respect to income varies from 1.014 to 1.573 . The Wald test was observed to be significant in two (out of three cases), which means that the elasticity coefficient is greater than unity. Thus, the health expenditure in the SEEHN countries can be argued as a luxury good. Since this is a test on the sample of 7 countries, 
TA B LE 6 Dynamic Ordinary Squares Least Estimator Results

\begin{tabular}{|c|c|c|c|c|}
\hline Dep. var. & Variable & Pooled & Weighted & Grouped \\
\hline \multirow[t]{2}{*}{$\ln (\mathrm{GDP})_{i t}$} & $\ln (\mathrm{HE})_{i t}$ & $0.435^{*}(9.444)$ & $0.371^{*} \quad(9.357)$ & $0.498^{\star} \quad(5.222)$ \\
\hline & $\ln (\mathrm{LE})_{i t}$ & $-0.032 \quad(-0.028)$ & $1.863^{* *}(0.040)$ & $-0.933 \quad(-0.504)$ \\
\hline \multirow[t]{2}{*}{$\ln (\mathrm{HE})_{i t}$} & $\ln (\mathrm{GDP})_{i t}$ & $1.573^{*}(8.635)$ & $1.344^{*}$ & $1.014^{*}(3.907)$ \\
\hline & $\ln (\mathrm{LE})_{i t}$ & $7.191^{*}(3.532)$ & $8.797^{*}$ & $11.319^{*} \quad(3.314)$ \\
\hline \multirow[t]{2}{*}{ Wald test $\dagger$} & $t$-statistic & $3.147^{*}$ & $1.914^{\star *}$ & 0.053 \\
\hline & $\chi^{2}$ statistic & $9.904^{*}$ & $3.663^{* *}$ & 0.003 \\
\hline
\end{tabular}

NOTES †Ho: Coefficient of $\ln (\mathrm{GDP})_{i t}$ is not greater than unity (equal to one). ${ }^{*}$ Significant at $1 \%$ levels. ${ }^{* *}$ Significant at $5 \%$ levels. $t$-statistics are reported in parentheses.

the reassessment of DoLs regression is made, in the way that in each of the subsequent evaluation one country was excluded, and the previously excluded was returned. Strong impact of economic growth on the health expenditure is not a result of outliers. The obtained values of coefficients, as well as the corresponding values of $t$-statistics are shown in table 7. When the panel pooled is the estimation method, the coefficients are statistically significant in all seven situations, and they range from 1.178 (when Croatia is excluded) to 1.857 (when Bulgaria is excluded). In the second case, when panel weighted is the estimation method, the results vary from 1.1 (when Croatia is excluded) to 1.527 (when Bulgaria is excluded). As it can be seen, the obtained coefficients are always statistically significant and greater than unity. Such results indicate that health care is a luxury good, and this is not the result of possible outliers.

Table 8 presents results of VECM model. The $t$-statistic for error correction term when the economic growth is a dependent variable indicates that the null hypothesis can't be rejected at the 5-percent level. On the other hand, when the health expenditure is considered as a dependent variable, the $t$-statistic for error correction term indicates that the null hypothesis can be rejected at the 1-percent level. From this, it can be concluded that the statistical long-run causality is unidirectional, and it runs from the economic growth to health expenditure. Also, in the short-run, there is one-way causality between the health expenditure and economic growth, and it runs from the economic growth to health. Elasticity of the health expenditure with respect to the income is 0.419 . In other words, $1 \%$ of increase in the economic growth increases the health expenditures for 0.419 percent. In contrast to the long-term results, health care is a necessary product and not a luxury. The results suggest that there exists a pos- 
TAB LE 7 Dynamic Ordinary Least Square Regression When One Country Is Excluded from the Analysis

\begin{tabular}{lrrrr}
\hline Excluded & $(1)$ & $(2)$ & $(3)$ & $(4)$ \\
\hline Romania & 1.515 & 10.072 & 1.347 & 8.247 \\
Moldova & 1.526 & 7.998 & 1.236 & 6.910 \\
FY R Macedonia & 1.620 & 8.844 & 1.401 & 7.567 \\
Croatia & 1.178 & 6.271 & 1.100 & 7.167 \\
B \& H & 1.606 & 8.027 & 1.513 & 6.938 \\
Bulgaria & 1.857 & 7.594 & 1.527 & 6.252 \\
Albania & 1.634 & 8.517 & 1.496 & 7.915 \\
\hline
\end{tabular}

NOTES Column headings are as follows: (1) coefficients on health expenditure (pooled), (2) $t$-statistics of the coefficients, (3) coefficients on health expenditure (weighted), (4) $t$ statistics of the coefficients.

TA B LE 8 Panel Vector Error Correction Model: Long Run Causality and Short Run Dynamics

\begin{tabular}{|c|c|c|c|c|}
\hline \multirow[t]{2}{*}{ Independent variables } & \multicolumn{4}{|c|}{ Dependent variables } \\
\hline & \multicolumn{2}{|c|}{$\Delta \ln (\mathrm{GDP})_{i t}$} & \multicolumn{2}{|c|}{$\Delta \ln (\mathrm{HE})_{i t}$} \\
\hline$e c_{i t-1}$ & -0.011 & $(-1.097)$ & $0.059^{*}$ & $(2.920)$ \\
\hline$\Delta \ln (\mathrm{GDP})_{i t-1}$ & $0.329^{*}$ & (5.399) & $0.419^{*}$ & $(3.270)$ \\
\hline$\Delta \ln (\mathrm{HE})_{i t-1}$ & 0.029 & $(0.708)$ & -0.093 & $(-1.084)$ \\
\hline$\Delta \ln (\mathrm{LE})_{i t-1}$ & 1.353 & $(1.416)$ & -1.126 & $(-0.561)$ \\
\hline \multirow[t]{2}{*}{ Constant } & $0.016^{*}$ & $(2.951)$ & $0.061^{*}$ & $(5.479)$ \\
\hline & \multicolumn{2}{|c|}{$R^{2}=0.347 ; \mathrm{DW}=2.152$} & \multicolumn{2}{|c|}{$R^{2}=0.128 ; \mathrm{DW}=1.78$} \\
\hline
\end{tabular}

NOTES ${ }^{*}$ indicates significance at the $1 \%$ level. $t$-statistics are reported in parentheses.

itive relationship between the health expenditure and economic growth in the long and short run. Furthermore, we also observed unidirectional causality between the health expenditure and economic growth.

\section{Conclusion and Policy Implications}

This paper employs the panel data econometrics to investigate a link between the health expenditure and economic growth in the SEEHN countries. Although many studies have recently been used conducted on the health care spending-economic growth nexus, there is no study that has investigated this relationship in SEHHN. Thus, this paper intends to fill the gap in the empirical literature in this tradition. Recently, these countries have invested a lot of efforts to improve the health care policy. Pol- 
icy makers started to consider the growth of economic activity as an appropriate tool which can generate improvements in health expenditures. Also health, as a part of human capital, has been recognized as one of the key drivers of economic growth.

The three main outcomes could be summarized as follows. First, there is co-integration among the economic growth, health expenditures and life expectancy. This suggests that there is a long-run relationship between the economic growth and health expenditure which is in accordance with the hypothesis number one. Second, in the long run, health expenditures cause positive changes in the economic growth. This result is in line with the second hypothesis. The third outcome is that in the long run, elasticity of the health expenditure with respect to the income is greater than unity. Therefore, health care can be considered as a luxury good. It can be pointed out that this finding is not the result of possible outliers. Nevertheless, in the short run, elasticity of the health expenditure with respect to income is less than unit, which means that health care is a necessary product. The third premise of the study is confirmed by a positive effect of the economic growth to health expenditure in the long and short-run.

Finally, on the basis of these outcomes, it is possible to suggest policy implications for these countries. It is essential for policymakers to formulate a long-run oriented policy, which will be directed towards the targeted increase of investment in health care, in order to increase the overall economic activity. It is necessary to strengthen the delivery of highquality health promoting services at all levels of care. Also, it is of great importance to harmonize the cross border public health legislation and enable a Free Trade Area from the public health perspective. Strengthening of the institutions and improving of inter-sectoral governance of the health sector at all levels, including health information infrastructure and regional cross-border information exchange, present very specific goals for these countries.

Since the empirical results confirmed that health is a good that is necessary for life in the short-run, an important role for this sector should be performed by the government. In contrast to the short-run, the long-run result implies that consumers' preferences drive the health expenditure above the economic growth. This suggests that public financing should play a subsidiary role. Consequently, the adequate combination of public and private financing will be needed to improve the health care policy in order to ensure that the SEEHN countries can benefit from the growth. 
These countries are lagging behind in the level of the income per capita, compared to the EU average. Due to the positive and statistically significant impact of the economic growth on health expenditure, it can be concluded, that shocks that have a negative impact on the economic growth to a large extent affect reduction of the health expenditure, too. For this reason, it is necessary for these countries to achieve a higher income in order to increase the investment in health care.

\section{References}

Abdullah, S. M., S. Siddiqua, and R. Huque. 2017. 'Is Health Care a Necessary or Luxury Product for Asian Countries? An Answer Using Panel Approach.' Health Economics Review 7 (1). https://doi.org/10.1186/ s13561-017-0144-8

Acemoglu, D., and S. Johnson. 2006. 'Disease and Development: The Effect of Life Expectancy on Economic Growth.' NB ER Working Paper Series 12269, National Bureau of Economic Research, Cambridge, MA.

Balaji, B. 2011. 'Causal Nexus between Public Health Expenditure and Economic Growth in Four Southern Indian States.' The IUP Journal of Public Finance 9 (3): 7-22.

Baltagi, B. H., and F. Moscone. 2010. 'Health Care Expenditure and Income in the oECD Reconsidered: Evidence from Panel Data.' Economic Modeling 27:804-11.

Barro, R. J. 1991. 'Economic Growth in a Cross Section of Countries.' Quarterly Journal of Economics 106 (2): 407-43.

Barros, P. P. 1998. 'The Black Box of Health Care Expenditure Growth Determinants.' Health Economics 7 (6): 533-44.

Blazquez-Fernandez, C., D. Cantarero, and P. Perez. 2014. 'Disentangling the Heterogeneous Income Elasticity and Dynamics of Health Expenditure.' Applied Economics 46 (16): 1839-54.

Bloom, D., and D. Canning. 2008. 'Population Health and Economic Growth.' Commission on Growth and Development Working Paper 24, World Bank, Washington, DC.

Breusch, T. S., and A. R. Pagan. 1980. 'The Lagrange Multiplier Test and Its Applications to Model Specification in Econometrics.' Review of Econometric Studies 47:239-53.

Bukenya, J. 2009. 'Do Fluctuations in Health Expenditure Affect Economic Growth?' The Open Economic Journal 2:31-38.

Cetin, M., and E. Ecevit. 2010. 'The Effect of Health Expenditures on Economic Growth: A Panel Regression Analysis on OECD Countries.' Doğuş Üniversitesi Dergis 11(2): 166-82.

Chen, W. 2015. 'Health Progress and Economic Growth in the UsA: The Continuous Wavelet Analysis.' Empirical Economics 50 (3): 831-55. 
Chen, W., J. A. Clarke, and N. Roy. 2014. 'Health and Wealth: Short Panel Granger Causality Tests for Developing Countries.' The Journal of International Trade \& Economic Development 23 (6): 755-84.

Chen, W. Y., J. W. Lee, T. Chang, and Y. H. Lin. 2013. 'Healthcare Expenditures and Economics Growth Nexus in 11 OECD Countries: Bootstrap Panel Causality Test.' The Empirical Economics Letters 12 (4): 375-85.

Chen, M.-Y., F.-L. Lin, and C.-K. Chang. 2009. 'Relations between Health Care Expenditure and Income: An Application of Local Quantile Regressions.' Applied Economics Letters 16 (2): 177-81.

Devlin, N., and P. Hansen. 2001. 'Health Care Spending and Economic Output: Granger Causality'. Applied Economics Letters 8 (8): 561-4.

Di Matteo, L. 2003. 'The Income Elasticity of Health Care Spending: A Comparison of Parametric and Nonparametric Approaches.' The European Journal of Health Economics 4:20-9.

Erdil, E., and I. Yetkiner. 2009. 'The Granger-Causality between Health Care Expenditure and Output: A Panel Data Approach.' Applied Economics 41 (4): 511-8.

Elk, van R., E. Mot, and P. H. Franses. 2010. 'Modeling Healthcare Expenditure: Overview of the Literature and Evidence from a Panel TimeSeries Model.' Expert Review of Pharmacoeconomics \& Outcomes Research 10 (1): 25-35.

Farag, M., A. Nanda Kumar, S. Wallack, D. Hodgkin, G. Gaumer, and C. Erbil. 2012. 'The Income Elasticity of Health Care Spending in Developing and Developed Countries.' International Journal of Health Care Finance and Economics 12 (2): 145-62.

Freeman, D. G. 2003. 'Is Health Care a Necessity or a Luxury? Pooled Estimates of Income Elasticity from us State-Level Data.' Applied Economics 35 (5): 495-502.

Fuchs, V. R. 1998. 'Who Shall Live? Health, Economics, Values, and Social Choice.' Economic Ideas Leading to the 21st Century 3:217-49.

Gerdtham, U. G., and M. Lothgren. 2002. 'New Panel Results on Cointegration of International Health Expenditure and GDP.' Applied Economics 34 (3): 1679-89.

- 2000. 'On Stationarity and Cointegration of International Health Expenditure and GDP.' Journal of Health Economics 19 (4): 461-75.

Gerdtham, U. G., J. Søgaard, F. Andersson, and B. Jönsson. 1992. 'An Econometric Analysis of Health Care Expenditure: A Cross-Section Study of the OECD Countries.' Journal of Health Economics 11 (1): 63-84.

Getzen, T. E. 2000. 'Health Care is an Individual Necessity and a National Luxury: Applying Multilevel Decision Models to the Analysis of Health Care Expenditures.' Journal of Health Economics 19 (2): 259-70.

Halici-Tuluce, N. S., I. Dogan, and C. Dumrul. 2016. 'Is Income Relevant 
for Health Expenditure and Economic Growth Nexus?' International Journal of Health Economics and Management 16:23-49.

Hall, S. G., and A. Milne. 1994. 'The Relevance of P-Star Analysis to U K Monetary Policy.' The Economic Journal 104 (424): 597-604.

Hartwig, J. 2010. 'Is Health Capital Formation Good for Long-Term Economic Growth? Panel Granger-Causality Evidence for oecd Countries.' Journal of Macroeconomics 32 (1): 314-25.

Hassan, S. A., K. Zaman, S. Zaman, and M. Shabir. 2014. 'Measuring Health Expenditures and Outcomes in Saarc Region: Health is Luxury?' Quality and Quantity 48 (3): 1421-37.

Hitiris, T., and J. Posnett. 1992. 'The Determinants and Effects of Health Expenditure in Developed Countries.' Journal of Health Economics 11 (2): 173-81.

Jarque, C., and A. Bera. 1980. 'Efficient Tests for Normality, Heteroskedasticity and Serial Independence of Regression Residuals.' Economics Letters 6 (3): 255-9.

Kao, C., and M. H. Chiang. 200o. 'On the Estimation and Inference of a CoIntegrated Regression in Panel Data.' In Nonstationary Panels, Panel Cointegration, and Dynamic Panels, edited by B. H. Baltagi, T. Fomby, and C. Hill, 179-212. Advances in Econometrics 15. Bingley: Emerald.

Khan, H. N., M. A. Khan, R. B. Razli, A. B. Sahfie, G. Shehzada, K. L. Krebs, and N. Sarvghad. 2016. 'Health Care Expenditure and Economic Growth in SAARC Countries (1995-2012): A Panel Causality Analysis.' Applied Research Quality Life 11 (3): 639-61.

Khan, J., and R. A. Mahumud. 2015. 'Is Healthcare a "Necessity" or "Luxury"? An Empirical Evidence from Public and Private Sector Analyses of South-East Asian Countries.' Health Economics Review 5 (1). https://doi.org/10.1186/s13561-014-0038-y

Kleiman, E. 1974. 'The Determinants of National Outlay on Health.' In The Economics of Health and Medical Care, edited by M. Perlman, 66-88. London: Palgrave Mcmillan.

Leu, R. R. 1986. 'Public and Private Health Services: Commentarities and Conflicts.' Oxford: Blackwell.

Lucas, E. R. 1988. 'On the Mechanics of Economic Development.' Journal of Monetary Economics 22 (1): 3-42.

Magazzino, C. 2011. 'GSP and Health Expenditure in Italian Regions.' International Journal of Business and Management 6 (12): 28-35.

Majdi, M. 2012. 'Study of the Relation Between Health and Economic Growth: Validation Empirical from a Panel of 15 Countries of the North and South Bank Mediterranean.' Interdisciplinary Journal of Contemporary Research in Business 4(1): 175-86.

Murthy, V., A. Okunade. 2009. 'The Core Determinants of Health Expen- 
ditures in the African Context: Some Econometric Evidence for policy' Health Policy 91 (1): 57-62.

Musgrove, P., R. Zeramdini, and G. Carrin. 2002. 'Basic Patterns in National Health Expenditure.' Bulletin of the World Health Organization $80(2): 134-42$.

Narayan, P. K., S. Narayan, and R. Smyth. 2011. 'Is Health Care Really a Luxury in OECD Countries? Evidence from Alternative Price Deflators.' Applied Economics 43 (25): 3631-43.

Newhouse, J. P. 1977. 'Medical Care Expenditure: A Cross-National Survey' Journal of Human Resources 12 (1): 115-25.

Ozturk, S., and E. Topcu. 2014. 'Health Expenditure and Economic Growth: Evidence from G8 Countries.' International Journal of Economic and Empirical Research 2 (6): 256-61.

Pattnayak, S. S., and A. Chadha. 2016. 'Is Health Care a Luxury? The Debate Revisited with new Evidence from Emerging Economies.' Applied Economics 48 (34): 3195-207.

Pedroni, P. 1999. 'Critical Values for Co-Integration Tests in Heterogeneous Panels with Multiple Regressors.' Oxford Bulletin of Economics and Statistics 61 (Special Issue): 653-70.

- 2000. 'Fully Modified ols for Heterogeneous Cointegrated Panels.' In Nonstationary Panels, Panel Cointegration, and Dynamic Panels, edited by B. H. Baltagi, T. Fomby, and C. Hill, 93-130. Advances in Econometrics 15. Bingley: Emerald.

- 2001. 'Purchasing Power Parity Tests in Co-integrated Panels.' The Review of Economics and Statistics 83 (4): 727-31.

Pesaran, M. H. 2007. 'A Simple Panel Unit Root Test in the Presence of Cross-Section Dependence.' Journal of Applied Econometrics 22 (2): 265-312.

Pradhan, R. P. 2010. 'The Long Run Relation between Health Spending and Economic Growth in 11 OECD Countries: Evidence from Panel Cointegration.' International Journal of Economic Perspectives 4 (2): 427-38.

Regional Cooperation Council. 2013. 'South East Europe 2020: Jobs and Prosperity in a European Perspective.' Regional Cooperation Council, N.p.

Roberts, J. 1999. 'Sensitivity of Elasticity Estimates for OECD Health Care Spending: Analysis of a Dynamic Heterogeneous Data Field.' Health Economics 8 (5): 459-72.

Sachs, J. D. 2014. The Age of Sustainable Development. New York: Columbia University Press.

Schieber, G., and A. Maeda. 1999. 'Health Care Financing and Delivery in Developing Countries.' Health Affairs 18 (3): 193-205.

Sen, A. 2005. 'Is Health Care a Luxury? New Evidence from oecd Data.' 
International Journal of Health Care Finance and Economics 5 (2): 14764.

Tang, C. F. 2011. 'Multivariate Granger Causality and the Dynamic Relationship between Health Care Spending, Income and Relative Price of Health Care in Malaysia.' Hitotsubashi Journal of Economics 52 (2): 199214.

Wang, K.-M., and Y.-M. Lee. 2018. 'The Impacts of Life Insurance Asymmetrically on Health Expenditure and Economic Growth: Dynamic Panel Threshold Approach.' Ekonomska istraživanja 31 (1): 440-60.

Westerlund, J. 2007. 'Testing for Error Correction in Panel Data.' Oxford Bulletin of Economics and Statistics 69 (6): 709-48.

Yavuz, N. C., V. Yilanci, and Z. A. Ozturk. 2013. 'Is Health Care a Luxury or a Necessity or Both? Evidence from Turkey' European Journal of Health Economics 14 (1): 5-10.

Ye, L., and X. Zhang. 2018. 'Nonlinear Granger Causality between Health Care Expenditure and Economic Growth in the OECD and Major Developing Countries.' International Journal of Environmental Research and Public Health 15 (9). https://doi.org/doi: 10.339o/ijerph15091953

Yu, T. H.-K., and H. Y. Chu. 2007. 'Is Health Care Really a Luxury? A Demand and Supply Approach.' Applied Economics 39 (9): 1127-31.

This paper is published under the terms of the Attribution-

NonCommercial-NoDerivatives 4.o International (CC B Y-NC-ND 4.0)

License (http://creativecommons.org/licenses/by-nc-nd/4.o/). 
Discovering Chinese Product Strategies

on Stimulating Attitude and Intention:

Involvement of Innovation, Country-of-Origin and Knowledge

\author{
Ramadania \\ Universitas Tanjungpura, Indonesia \\ ramadhania@ekonomi.untan.ac.id \\ Rianti Ardana Reswari \\ Universitas Tanjungpura, Indonesia \\ riantiardana@student.untan.ac.id \\ Endang Dhamayantie \\ Universitas Tanjungpura, Indonesia \\ endang.dhamayantie@ekonomi.untan.ac.id
}

Globalization has succeeded in broadening consumers' choice via technological assistance which provides sufficient variety of information. Companies shall face competition, both at domestic and international level, which is more intensified than prior to globalization. Chinese brands are increasingly popular overseas and reaching out to compete with other global brands. Global consumers are also continuously looking up for newest product innovations yet having the lowest price tag in the market. Their search brings about knowledge and attention on Chinese brands. This research aims to analyse the influence of product innovation, country of origin, and product knowledge on purchase intention through brand attitude. To collect data, close-ended questionnaires were handed over to 100 respondents. The data were then calculated using SmartpLs 3.2.7. The findings indicated that in order to create more favourable brand attitude, a company needs to focus on efforts to generate customer memory about product specification.

Key Words: product innovation, country of origin, product knowledge, brand attitude, purchase intention

JEL Classification: M3, $\mathrm{O} 3$

https://doi.org/10.26493/1854-6935.16.215-234

\title{
Introduction
}

Wide expansion of international markets for consumer goods resulted from globalization affects companies' approaches toward modern cus- 
tomers. A recent phenomenon shows that Chinese firms are no longer focusing on domestic market and going 'global.' Current researchers found that there are many underlying motives for Chinese firms to go global, in which 'creating a single and globally recognized brand' is one (Fetscherin and Sardy 2008; Fan 2006). Constantly, global firms remain focused on managing sales volume and brand equity by offering customers some values and beliefs which can stimulate purchase intention. One of the newly emerging concepts in business literature is brand attitude (Ghorban 2012). Some researchers pointed out that brand attitude is formed to achieve an ultimate goal of creating consumers' purchase intention ( $\mathrm{Si}$ cilia, Ruiz, and Reynolds 2006). Prior research empirically investigated the concept and demonstrated a significant, positive relationship between attitude and purchase intentions of consumers (Sheeraz et al. 2016; Chan et al. 2013). Globalization is highly related to advancement of technology in business sector. Product innovation refers to an adoption of a new or significantly improved production method (Seng and Ping 2016). It is conducted to maintain a sustainable competitive advantage. Hence, product innovation has a considerable influence on attitudes and purchase intention of potential consumers.

Expansion of international market affects consumers' perspectives toward a product's country of origin. Consumers tend to possess their own perception towards country of origin. Along with progression of information, consumers' attitudes to domestic and foreign products are gradually shifting. The products of developing countries are not perceived to have good quality and negative attitudes toward these products are studied by (Schooler 1965). This study discusses consumers' views towards Chinese products. In contrast, other studies found that the more global the brand is, the better quality it is offered; hence, it receives more favourable attitude (Holt et al. 2004).

Various information and choice are currently available one click away from customers. It is a particularly important source of information for customers because they rely on product information to lower possible dissatisfaction or perceived risk (Olson and Jacoby 1972). In a recent study, Cakici and Shukla (2017) pointed out that consumers' product knowledge has a significant effect on their purchase intention. Attitudes also acted as a mediator for the relationship between product knowledge and purchase intention (Juharsah and Hartini 2014). Currently, some new brands entering global market are mostly from China and those brands are demanded by consumers. Lack of production of domestic product 
and product necessity factors as well contributes to shape different consumer attitudes towards certain foreign products (Ramadania, Gunawan, and Rustam 2015) For instance, Xiaomi's action camera succeeds in penetrating new market and creating favourable brand attitude, which in turn, generate purchase intention. Emerging demands for action cameras in Indonesia remain strong, due to rising trends of travelling. In addition, some Indonesian consumers usually capture every moment to be uploaded to social media. This consumer behaviour phenomenon is seen as a promising opportunity. Some previous studies (Seng and Ping 2016; Juharsah and Hartini 2014) solely examined the relationship between attitude and purchase intention without any mediation from brand attitude. Past literatures did not incorporate product innovation, country of origin, and product knowledge into one conceptual model.

\section{Literature Review}

Product Innovation. Product innovations refers to cross-functional activities within a company. In order to create a successful innovation process, marketing effort needs to be integrated with $\mathrm{R} \& \mathrm{D}$, manufacturing, and finance (Mohr and Sarin 2009). Technical and management systems within an organization shall simultaneously innovate to discover new or distinctive market offerings. When an innovation succeeds, it brings a superior value to the organization.

Country of Origin (COO). Anwar et al. (2013) stated that coo is described as different brands belong to the different countries. The brands belong to a certain country can be included into country-of-origin. Consumers form their expectations based on the perceived image of the country. The impact of coo also known from 'made in' will probably affect consumer attitudes and purchase intentions toward foreign and domestic product is most often developed study in the field of international marketing (Ramadania, Gunawan, and Jamaliah 2013; Amine 2008).

Product Knowledge. Lin and Zhen (2005) asserted that product knowledge is generated from awareness or understanding about the product, and also reflects consumers' confidence about it. In other words, Beatty and Smith (1987) referred to product knowledge as a consumer's perception toward certain products, including their previous experience of using the product. Consumers construct various product knowledge structure based on various degrees of familiarity toward a product (Park and 
Lessig 1981). Those with higher product knowledge tend not to employ preconceived idea to judge product quality.

Brand Attitude. Brand attitude is a needed communication effects if brand purchase is to occur (Percy and Rossiter 1992). It refers to onedimensional consumer attitude as a sum of evaluations on a product, which may be effective to examine attitude as a multidimensional construct consisting of a network of interconnected beliefs and evaluations (Bagozzi and Silk 1983).

Consumer Purchase Intention. Purchase intention is a decision-making process which studies the reason to buy a particular brand by a consumer (Shah et al. 2012). Hellier et al. (2003) believed that behaviour intention is the judgment or opinion about repurchasing a particular product from the same enterprise under the current premise and possible conditions of an individual. Behaviour intention is a subjective tendency for consumers to purchase their targeted product.

\section{HYPOTHESIS DEVELOPMENT}

Consumer purchase intention is frequently cited by marketing strategists as an advice about new progress and/or existing product decision. It can be simplified using 'likelihood of buying' and 'product recommendation.' A company may propose some strategies to influence consumers' judgement toward their brand or product. Previous literatures explained that novelty-seekers consumers tend to have more favourable attitudes toward acquiring innovative products (Manning, Bearden, and Madden 1995). This attitude influences intention and behaviour through its effects on attitude (Ajzen and Fishbein 2005). COO is a factor considered by consumers on purchase decision making (Lee 2013). Somansundaram (1993) argued that consumers with high level of product knowledge also form extreme beliefs and attitudes toward a company or its products. Hence, it is concluded that product knowledge affects purchase intention (Lin and Lin 2007). A positive attitude toward a brand allows consumers to decide on their purchase; while negative brand attitude obstructs consumers in making purchases (Cheng and Chang 2008).

From figure 1, the formulated hypotheses are depicted besides the arrows in the conceptual framework. Scholars believed that product innovation is one of the consideration factors affecting consumers to make purchase decision (Boyd and Charlotte 1999). It also shows that product innovation plays important role in determining potential consumers' 


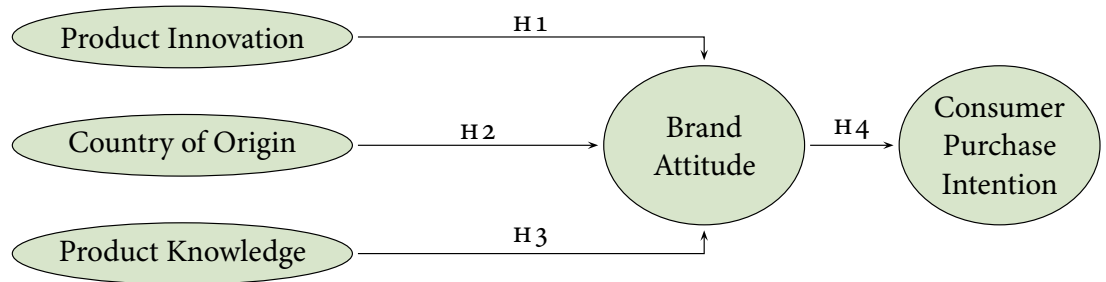

FIGURE 1 Research Hypothesis

purchase and attitude. Novelty-seekers consumers tend to have more favourable attitudes toward acquiring innovative products (Manning, Bearden, and Madden 1995). Therefore, the first hypothesis is formulated, as follows:

H1 Product innovation has significantly influence with brand attitude.

If the product comes from highly reputable country, most consumers have positive attitudes toward it. A person seems to hold a distinct and specific opinion about various aspects of a product or brand which later affects their intention to buy (Oh and Jeong, 2015). On the other hand, if the product comes from non-reputable country, consumers possibly forms negative attitudes (Bhakar and Bhakar 2013). Based on such theoretical support, the second hypothesis is formulated:

$\mathrm{H} 2$ Country of origin has significantly influence with brand attitude.

Lin and Chen (2006) highlighted that product knowledge is positively related and significantly influences consumers' purchasing decisions. However, through attitude as mediation variable, product knowledge significantly affects purchase intention (Juharsah and Hartini 2014). Consumers show their affections distinctively for a brand based on their own personal knowledge. A possible explanation for this different behaviour lies in the fact that novices lack in the necessary knowledge and experience to distinguish important product attributes (Beattie 1982). Hence, it is concluded that:

$\mathrm{H} 3$ Product knowledge has significantly influence with brand attitude.

A brand can fulfil multiple roles to influence consumers' decisionmaking process or choice behaviour (Sheeraz et al. 2016). Commonly, consumers' attitudes strongly influence their purchase behaviours (Taute et al. 2017; Priester et al. 2004). Positive attitude toward a brand allows consumers to make purchases; while negative brand attitudes obstruct 
consumers in making purchases (Cheng and Chang 2008). Thus, the fourth hypothesis is:

$\mathrm{H} 4$ Brand attitudes significantly influence with consumer purchase intention.

\section{Research Methodology}

The primary data in this study were obtained from online and printed questionnaires. The raw data were subsequently proceeded using SmartP LS 3.2.7 for Windows to determine the frequency of responds from the respondents. Likert scale was employed to measure research variables in which the respondents were asked to indicate a degree of agreement and disagreement about the variables and ranged between 1-5, from very low to very high (Suwatno 2007). Research population was classified as infinite; hence, as the sample, this research used purposive sampling which was determined after the samples fulfilled certain criterion. Hair et al. (2010) stated that minimum sample size shall be 100-150 to ensure stable Maximum Likelihood Estimation (MLE). Total sample in this research was 100 respondents who were identified as potential Chinese brands consumers.

PLS began with testing measurement model to test the validity of constructs and reliability of instruments. Validity test in PLS was implemented through convergent validity test, discriminant validity test, and average variance extracted (AVE) test. Furthermore, reliability test was used to measure the consistency of items in measuring the variables. It can also be used to measure respondents' consistency in answering instruments. Overall, the response rate for online survey was higher than paper survey in this research.

\section{Data Analysis and Results}

There were some specific characteristics of the respondents for this study, including gender, education, age, revenue, and occupation. The total number of female respondents were as many as 54 females (54\%). Most respondents ( $66 \%$ or 66 people), who were interested in Chinese brands, were freshman undergraduate students. Those below 31 years old were estimated to be accounted for $95 \%$ of the total respondents. It was also observed that most respondents earned less than IDR 3 million for their monthly incomes ( $78 \%$ of total respondents). Majority ( $70 \%)$ respondents were college students. Table 2 illustrates summary of characteristics of respondents. 
TABLE 1 Measurement of Constructs

\begin{tabular}{|c|c|c|}
\hline Variable & Indicator & Item \\
\hline \multirow{4}{*}{$\begin{array}{l}\text { Product Inno- } \\
\text { vation (X1), } \\
\text { adapted from } \\
\text { Damanpour } \\
\text { (1999). }\end{array}$} & Technological innovation & $\begin{array}{l}\text { The products regularly update its pro- } \\
\text { duction technology. }\end{array}$ \\
\hline & Service innovation & $\begin{array}{l}\text { The products instantly update the ser- } \\
\text { vice through Internet. }\end{array}$ \\
\hline & New products & $\begin{array}{l}\text { The products often lead ahead of other } \\
\text { brands in launching new products. }\end{array}$ \\
\hline & Market breakthrough & $\begin{array}{l}\text { The products readily update its func- } \\
\text { tions to meet consumer's needs. }\end{array}$ \\
\hline \multirow{7}{*}{$\begin{array}{l}\text { Country of } \\
\text { Origin (x2), } \\
\text { adapted from } \\
\text { Yasin, Noor, } \\
\text { and Mohamad } \\
(2007) .\end{array}$} & $\begin{array}{l}\text { Innovation of the country } \\
\text { in production }\end{array}$ & $\begin{array}{l}\text { I am sure that Chinese product have } \\
\text { great innovation. }\end{array}$ \\
\hline & $\begin{array}{l}\text { The level of technological } \\
\text { progress of the country of } \\
\text { origin }\end{array}$ & $\begin{array}{l}\text { I look for the label 'Made in China' to } \\
\text { ensure that I buy products with newest } \\
\text { technology. }\end{array}$ \\
\hline & Production design & $\begin{array}{l}\text { I look for product from China to ensure } \\
\text { that the camera that I will purchase have } \\
\text { good design. }\end{array}$ \\
\hline & Productive creativity & $\begin{array}{l}\text { I believe China have variety of products } \\
\text { to choose. }\end{array}$ \\
\hline & Production quality & $\begin{array}{l}\text { I am seeking for Chinese product to } \\
\text { ensure that I buy good quality product. }\end{array}$ \\
\hline & $\begin{array}{l}\text { The prestige of the home } \\
\text { country of the brand }\end{array}$ & $\begin{array}{l}\text { I believe that Chinese product deter- } \\
\text { mining the brand prestige. }\end{array}$ \\
\hline & $\begin{array}{l}\text { The image of the home } \\
\text { country of the brand as } \\
\text { developed country }\end{array}$ & $\begin{array}{l}\text { I believe product from China determin- } \\
\text { ing country image that I perceived. }\end{array}$ \\
\hline
\end{tabular}

Continued on the next page

By continue making progress in innovation and new approach toward mid-range market, Chinese firms have been tremendously successful in recent years. Most respondents admittedly agree that Chinese brands regularly upgraded all types of electronic devices, which were also seen as attempts to survive in market competition. The result affirmed that country of origin served as an information cue prior to product purchasing. Country of origin or consumers' attitude towards products' origin can be influenced by cultural values and perceptual stereotypes. Product knowledge was associated with information and experience which built a memory of a product. Gathering information was not a big deal for customers in the Internet era. Relatively, Chinese brands were perceived in a posi- 
TAB LE 1 Continued from the previous page

\begin{tabular}{|c|c|c|}
\hline Variable & Indicator & Item \\
\hline \multirow{4}{*}{$\begin{array}{l}\text { Product Knowl- } \\
\left.\text { edge ( } \mathrm{x}_{3}\right) \text {, } \\
\text { adapted from } \\
\text { Brucks (1985) } \\
\text { and Lin and } \\
\text { Chen (2006). }\end{array}$} & $\begin{array}{l}\text { Knowledge about the prod- } \\
\text { uct }\end{array}$ & I feel knowledgeable about the products. \\
\hline & Willingness to understand & $\begin{array}{l}\text { I want to understand the products ac- } \\
\text { tively. }\end{array}$ \\
\hline & $\begin{array}{l}\text { Memory of product infor- } \\
\text { mation }\end{array}$ & $\begin{array}{l}\text { I actually stored in my memory about } \\
\text { the products' information. }\end{array}$ \\
\hline & $\begin{array}{l}\text { Differentiation of product } \\
\text { and brand }\end{array}$ & $\begin{array}{l}\text { I am able to tell the differences of the } \\
\text { products and other brand of product } \\
\text { firms. }\end{array}$ \\
\hline \multirow{4}{*}{$\begin{array}{l}\text { Brand Attitudes } \\
\text { (Y1), adapted } \\
\text { from Miniard } \\
\text { et al. (1991). }\end{array}$} & Favourability & $\begin{array}{l}\text { My attitude toward product' brand is } \\
\text { favourable. }\end{array}$ \\
\hline & Conation component & $\begin{array}{l}\text { My attitude toward product' brand is } \\
\text { positive. }\end{array}$ \\
\hline & Affective component & I like product' brand. \\
\hline & Cognition component & $\begin{array}{l}\text { My overall evaluation of product' brand } \\
\text { is good. }\end{array}$ \\
\hline \multirow{4}{*}{$\begin{array}{l}\text { Consumer Pur- } \\
\text { chase Intention } \\
\text { (Y2), adapted } \\
\text { from Barber et } \\
\text { al. (2012). }\end{array}$} & Explorative interest & I intend to try the products. \\
\hline & Referential interest & $\begin{array}{l}\text { I would consider purchasing the prod- } \\
\text { ucts. }\end{array}$ \\
\hline & Transactional interest & I plan on buying the products. \\
\hline & Preferential interest & I am interested in using the products. \\
\hline
\end{tabular}

tive attitude from most respondents. Chinese brands themselves mostly widen their market share by offering a cheaper alternative for consumers who demanded for lower product price, compared to either Western or Eastern products. Furthermore, the data interpretation in this study included outer model, inner model, mediating effect, and $t$-statistics test result. The outer model in partial least square (PLS) specified the degree of validity and reliability of the relationships between latent variables and indicators. Firstly, convergent validity occurred when the construct measurements were correlated with one another. As a general rule of thumb, outer loadings should obtain the value of 0.70 or higher; while 0.5 AVE score was considered satisfactory (Avkiran 2018). Items with outer loadings of 0.6 might be considered acceptable, while items with outer loadings less than 0.5 should be eliminated from analysis (Ghozali 2008). The results of validity test are presented in table 3 , including outer loadings and AVE scores. 
TABLE 2 Characteristics of Respondents

\begin{tabular}{|c|c|c|c|}
\hline Category & Item & $f$ & $\%$ \\
\hline \multirow[t]{2}{*}{ Gender } & Male & 46 & 46 \\
\hline & Female & 54 & 54 \\
\hline \multirow[t]{5}{*}{ Education } & Senior High School & 66 & 66 \\
\hline & Diploma Degree & 4 & 4 \\
\hline & Bachelor Degree & 27 & 27 \\
\hline & Master Degree & 2 & 2 \\
\hline & Doctoral Degree & 1 & 1 \\
\hline \multirow[t]{5}{*}{ Age } & $17-20$ years old & 26 & 26 \\
\hline & $21-30$ years old & 69 & 69 \\
\hline & $31-40$ years old & 3 & 3 \\
\hline & $41-50$ years old & 1 & 1 \\
\hline & $\geq 50$ years old & 1 & 1 \\
\hline \multirow[t]{5}{*}{ Revenue } & $<$ Rp. 3.000.000 & 78 & 78 \\
\hline & $>$ Rp. 3.000.000-7.500.000 & 17 & 17 \\
\hline & > Rp. $7.500 .000-11.500 .000$ & 1 & 1 \\
\hline & $>$ Rp. $11.500 .000-15.500 .000$ & 2 & 2 \\
\hline & $>$ Rp. 15.500 .000 & 2 & 2 \\
\hline \multirow[t]{6}{*}{ Occupation } & College Student & 70 & 70 \\
\hline & Civil Servant & 2 & 2 \\
\hline & Private Employees & 18 & 18 \\
\hline & Entrepreneur & 4 & 4 \\
\hline & Housewife & 1 & 1 \\
\hline & Unemployment & 5 & 5 \\
\hline
\end{tabular}

Invalid measurement could mystify the research objectives and data interpretations; hence, it should be removed to clearly investigate the correct measurement items and obtain desired results. Moreover, discriminant validity was an assessment to ensure that a reflective construct has the strongest relationship with its own indicators in PLS path model (Hair et al. 2017). The outer loadings and constructs were adequate yet valid, as illustrated in table 4 .

Finally, reliability test is vitally important for both data stability and consistency. The measurement model with composite reliability above the threshold value of 0.70 for each construct was considered satisfactory. 
TABLE 3 Convergent Validity Test

\begin{tabular}{|c|c|c|c|}
\hline Construct & Measurement item & Loading & AVE \\
\hline \multirow[t]{4}{*}{ Product Innovation (x 1) } & PI1 & 0.893 & 0.680 \\
\hline & PI 2 & 0.827 & \\
\hline & PI 3 & * & \\
\hline & PI4 & 0.749 & \\
\hline \multirow[t]{7}{*}{ Country of Origin (x 2) } & $\mathrm{COO} 1$ & 0.706 & 0.538 \\
\hline & $\mathrm{COO} 2$ & 0.740 & \\
\hline & $\mathrm{COO} 3$ & 0.756 & \\
\hline & $\mathrm{COO} 4$ & 0.700 & \\
\hline & $\operatorname{coo} 5$ & 0.765 & \\
\hline & $\operatorname{coo} 6$ & * & \\
\hline & $\operatorname{coo} 7$ & * & \\
\hline \multirow[t]{4}{*}{ Product Knowledge ( $\left.\mathrm{x}_{3}\right)$} & $\mathrm{PK} 1$ & 0.881 & 0.777 \\
\hline & $\mathrm{PK} 2$ & 0.866 & \\
\hline & $\mathrm{PK} 3$ & 0.896 & \\
\hline & $\mathrm{PK} 4$ & * & \\
\hline \multirow[t]{4}{*}{ Brand Attitude (Y 1 ) } & BA 1 & 0.867 & 0.774 \\
\hline & BA 2 & 0.883 & \\
\hline & BA 3 & 0.885 & \\
\hline & B A 4 & 0.885 & \\
\hline \multirow[t]{4}{*}{ Purchase Intention (Y 2) } & CPI 1 & 0.886 & 0.786 \\
\hline & $\mathrm{CPI} 2$ & 0.812 & \\
\hline & $\mathrm{CPI} 3$ & 0.907 & \\
\hline & CPI4 & 0.937 & \\
\hline
\end{tabular}

NOTES ${ }^{\star}$ Deleted due to low outer loading result.

The reliable statement item also required Cronbach Alpha value higher than 0.60 for all constructs (Abdillah and Hartono 2015). Reliability test results were summarized in table 5 .

Based on the summaries in table 5 , composite reliability values for all constructs fulfilled the requirement of 0.70 . The results displayed that product innovation obtained 0.932 ; country of origin was 0.853 ; product knowledge recorded 0.86 ; brand attitude was 0.912; and purchase intention was recorded at 0.936 . Thereby, high composite reliability values led to the consistency of Cronbach Alpha scores for all constructs. Thus, it 
TABLE 4 Discriminant Validity Test

\begin{tabular}{llllll}
\hline$(1)$ & $(2)$ & $(3)$ & $(4)$ & $(5)$ & $(6)$ \\
\hline PI1 & 0.893 & 0.295 & 0.450 & 0.485 & 0.375 \\
PI2 & 0.827 & 0.274 & 0.365 & 0.470 & 0.371 \\
PI4 & 0.749 & 0.277 & 0.365 & 0.353 & 0.228 \\
COO1 & 0.259 & 0.706 & 0.303 & 0.459 & 0.423 \\
COO2 & 0.336 & 0.740 & 0.209 & 0.282 & 0.262 \\
COO3 & 0.156 & 0.756 & 0.199 & 0.266 & 0.248 \\
COO4 & 0.389 & 0.700 & 0.196 & 0.417 & 0.341 \\
COO5 & 0.196 & 0.765 & 0.304 & 0.352 & 0.310 \\
PK1 & 0.389 & 0.248 & 0.881 & 0.395 & 0.421 \\
PK2 & 0.477 & 0.318 & 0.866 & 0.452 & 0.466 \\
PK3 & 0.382 & 0.327 & 0.896 & 0.445 & 0.481 \\
BA1 & 0.484 & 0.566 & 0.479 & 0.867 & 0.687 \\
BA2 & 0.452 & 0.412 & 0.387 & 0.883 & 0.714 \\
BA3 & 0.434 & 0.378 & 0.389 & 0.885 & 0.734 \\
BA4 & 0.509 & 0.428 & 0.468 & 0.885 & 0.735 \\
CPI1 & 0.339 & 0.455 & 0.513 & 0.745 & 0.886 \\
CPI2 & 0.311 & 0.258 & 0.377 & 0.568 & 0.812 \\
CPI3 & 0.392 & 0.402 & 0.491 & 0.751 & 0.902 \\
CPI4 & 0.379 & 0.459 & 0.449 & 0.798 & 0.937 \\
\hline
\end{tabular}

Notes Column headings are as follows: (1) item, (2) Product Innovation, (3) Country of Origin, (4) Product Knowledge, (5) Brand Attitude, (6) Purchase Intention.

TABLE 5 Reliability Test

\begin{tabular}{lrrrr}
\hline Variable & $(1)$ & $(2)$ & $(3)$ & $(4)$ \\
\hline Product Innovation (x 1) & 0.765 & 0.932 & $>0.70$ & Reliable \\
Country of Origin (x 2) & 0.790 & 0.853 & $>0.70$ & Reliable \\
Product Knowledge (x 3) & 0.856 & 0.864 & $>0.70$ & Reliable \\
Brand Attitude (Y 1) & 0.903 & 0.912 & $>0.70$ & Reliable \\
Purchase Intention (Y 2) & 0.909 & 0.936 & $>0.70$ & Reliable \\
\hline
\end{tabular}

NOTES Column headings are as follows: (1) Cronbach alpha, (2) composite reliability, (3) scale, (4) description.

confirmed the reliability of measurement items. Meanwhile, the structural model was also acknowledged as inner model. It emphasized on 


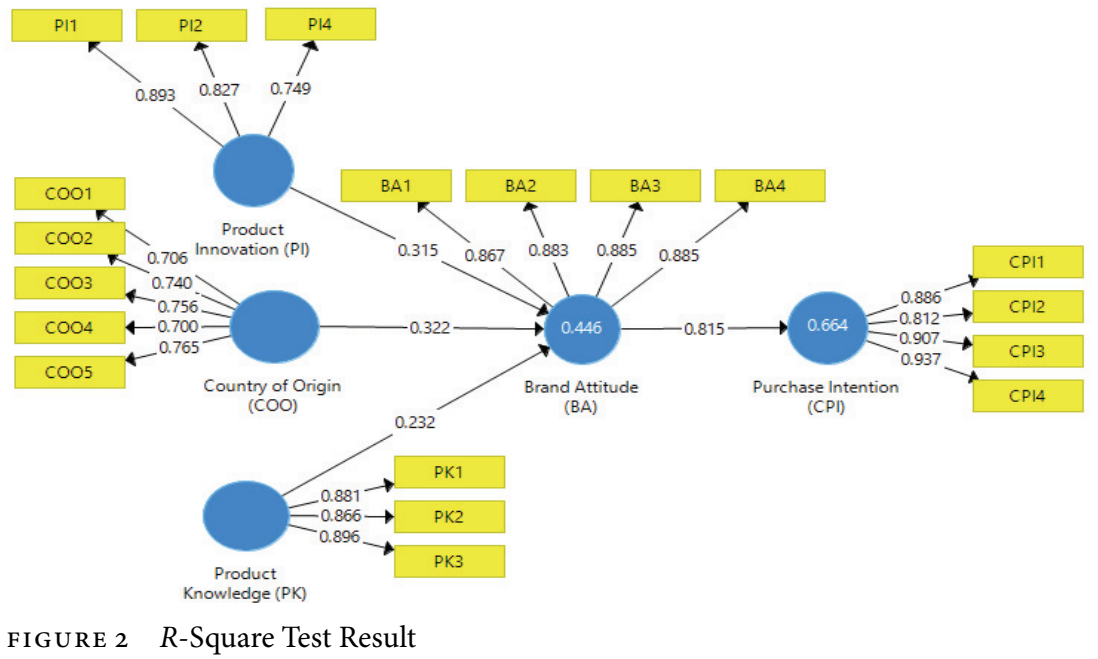

the relationships between independent and dependent latent variables. Inner model evaluation consisted of $R$-square measurement and path coefficient results. The coefficient of determination $\left(R^{2}\right)$ indicated the differing variance in endogenous latent variables from its independent latent variables. Conversely, if the results of $R^{2}$ was $0.67,0.33$, and 0.19 , it proved that the models were subsequently 'good,' 'moderate,' and 'weak' (Ghozali 2008). Figure 2 contains the illustration of $R^{2}$ test results based on SmartpLs 3.2.7 calculations.

The total of $44.6 \%$ specified the proportion of variance in brand attitude which was explained by product innovation, country of origin, and product knowledge. $R$-square of $66.4 \%$ measured the ability of dependent latent variables (i.e. purchase intention) to explain the variances of independent latent variables. It was also proved that $R^{2}$ was statistically significant. After assessing the quality of outer model, it starting from an evaluation of structural results by measuring path coefficient (Sanchez 2013). Path coefficient test results offered theoretical measures of the relationship between constructs and indicators in structural model. The numbers on the arrows in bootstrapping output were called path coefficient. The weight of different path coefficients represented the rank of each variable's relative statistical importance (Wong 2013). All path coefficients for each construct were positive, as illustrated in figure 3 .

A mediation could only occur when there was a causal effect between independent and dependent variables which is caused by an intervention or a mediating effect. Biehal, Stephens, and Curio (1992) examined an 


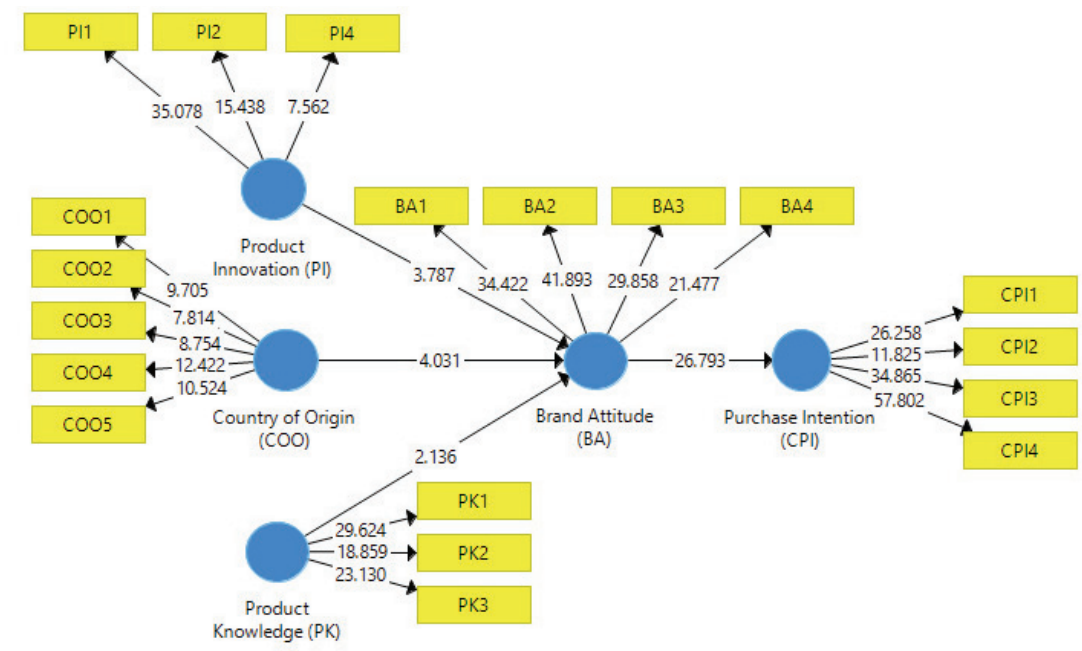

FIGURE 3 Bootstrapping Test

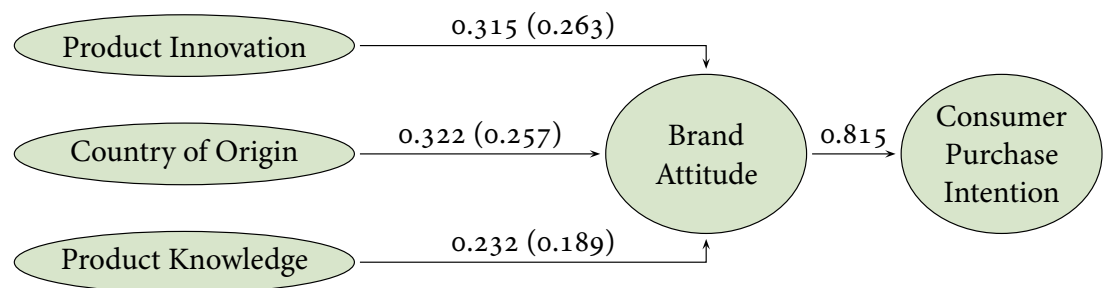

FIGURE 4 Mediating Effect (indirect effect in parentheses)

attitude toward a brand as a mediator toward purchase intention. In this study, the total indirect effects are illustrated in figure 4 and table 6.

Mediation test was to discover if a mediating construct can significantly carry the ability of an independent variable to a dependent variable (Ramayah, Lee, and In 2011). Generally, a mediator was a proportion of total direct effects of exposure on causal relationship, which was interpreted by an indirect effect. However, the total indirect effect and direct effect were both significant. If the direct path was significant, it implied that there was a mediating variable; hence, bootstrapping procedure shall be redone. If the indirect path was not significant after bootstrapping, there was no mediation. If it is significant, in order to examine the strength of mediating effect, it was recommended to calculate variance accounted for (VAF) value in SmartPLs 3.2.7. According to Hair et al. (2014), a VAF value greater than $80 \%$ represented a full mediation, a 
TABLE 6 Mediating Effect

\begin{tabular}{lrrr}
\hline Item & Indirect Effect & Total Effect & VAF \\
\hline $\begin{array}{l}\text { Product Innovation } \rightarrow \text { Brand Attitude } \\
\rightarrow \text { Purchase Intention }\end{array}$ & 0.263 & 0.578 & $45 \%^{*}$ \\
$\begin{array}{l}\text { Country of Origin } \rightarrow \text { Brand Attitude } \\
\rightarrow \text { Purchase Intention }\end{array}$ & 0.257 & 0.579 & $44 \%^{*}$ \\
$\begin{array}{l}\text { Product Knowledge } \rightarrow \text { Brand Attitude } \\
\rightarrow \text { Purchase Intention }\end{array}$ & 0.189 & 0.421 & $45 \%^{*}$ \\
\hline
\end{tabular}

NOTES *Partial mediation.

value between $20 \%$ and $80 \%$ indicated a partial mediation, and a value less than $20 \%$ meant no mediation. VAF was computed by dividing total indirect effect and total effect, then multiplied by 100. Meanwhile, the total effect itself was based on the sum of direct effect and indirect effect.

As illustrated above, table 6 implied that the relationships were all classified as partial mediations. James and Brett (1984) suggested that the model assumed it has partial mediation, i.e., the mediated path via $M$ (e.g. brand attitude) is accounted for some effects of $X$ (e.g. product innovation) on Y (e.g. purchase intention). Mediating effect's results presented in table 6 explained that all variables had mediating effects on their relationships with dependent variables and the range of VAF values were approximately $45 \%$. It is important to recognize that hypothesis testing aimed to test some theoretical propositions. In the context of PLS-SEM, hypothesis testing was frequently conducted through the calculation of $t$-statistics or $p$-values for each hypothesis. The significance threshold for $t$-values was 1.96 for $95 \%$ confidence level (Hair et al. 2014). Hence, if the result of $p$-value is less than 0.05 or $t$-statistics is more than 1.96 (with $\alpha=$ 0.05 or $5 \%$ ), then it is assumed that alternative hypothesis was accepted. Table 7 summarizes the result of hypothesis testing in SmartpLs 3.2.7.

Table 7 presents the outputs of standardized path coefficient related to all variables. The hypotheses were accepted and had positive direct effects on related variables. New product development keeps companies growing. Chinese brands offered some different strategies to broaden their market by offering low-priced products and producing various product lines. This posit is supported by past literatures, which suggested that brand attitude was influenced by product innovation from specific brand names (Ouellet 2006). The overall relationship between product innovation and brand attitude was supported $(\beta=0.315 ; t$-statistic $=3.787 ; p=$ $\mathrm{o.00O}$ ); therefore, $\mathrm{H} 1$ is accepted. The perception about some products' 
TABLE 7 Hypothesis Testing

\begin{tabular}{lrrrrrr}
\hline Item & $(1)$ & $(2)$ & $(3)$ & $(4)$ & $(5)$ & $(6)$ \\
\hline $\begin{array}{l}\text { Product Innovation } \rightarrow \\
\text { Brand Attitude }\end{array}$ & 0.315 & 0.317 & 0.083 & 3.787 & 0.000 & $\mathrm{H}^{*}$ \\
$\begin{array}{l}\text { Country of Origin } \rightarrow \\
\text { Brand Attitude }\end{array}$ & 0.322 & 0.331 & 0.081 & 4.031 & 0.000 & $\mathrm{H}^{*}$ \\
$\begin{array}{l}\text { Product Knowledge } \rightarrow \\
\text { Brand Attitude }\end{array}$ & 0.232 & 0.232 & 0.108 & 2.136 & 0.000 & $\mathrm{H} 3^{*}$ \\
$\begin{array}{l}\text { Brand Attitude } \rightarrow \\
\text { Purchase Intention }\end{array}$ & 0.815 & 0.818 & 0.030 & 26.793 & 0.033 & $\mathrm{H} 4^{*}$ \\
\hline
\end{tabular}

Notes Column headings are as follows: (1) original sample, (2) sample mean, (3) standard deviation, (4) $t$-statistics, (5) $p$-values, (6) description. * Accepted.

country of origin currently served as an important evaluation aspect for a certain brand. It is proved that different countries had their respective impression in consumers' minds. However, this study proved that products from developing country (i.e. China) gradually started to be perceived more positively by consumers. Over one hundred studies were conducted on country-of-origin information and its effect on consumers' attitudes toward certain products (Hsieh 2004). It was concluded that there was a significant relationship between country of origin and brand attitude ( $\beta$ $=0.322 ; t$-statistic $=4.031 ; p=0.000$ ); thus, $\mathrm{H} 2$ is accepted.

The visibility of products knowledge on the media also aimed to provide information and recommendation to consumers. However, Chinese product knowledge may not play an important role in consumer prepurchase evaluation. Despite low $t$-statistics score compared to other independent latent variables, product knowledge still yielded significant relationship toward brand attitude. It is believed that there is a correlation between product knowledge and consumer beliefs and attitudes towards a company or its products (Somansundaram 1993). The result indicated that product knowledge had a significant, positive relationship with brand attitude $(\beta=0.232 ; t$-statistic $=2.136 ; p=0.000)$; hence, $\mathrm{H}_{3}$ is accepted. Brand attitude was related to consumers' purchase intention and company's financial performance, because a brand was a valuable asset for a company. Low price and rapid innovation are Chinese brand's business plan. Market response was very favourable, because consumers have more flexibility in choosing products. More favourable attitude toward a certain behaviour could strengthen individual intention to perform the behaviour itself (Ajzen 1991). A significant, positive relationship between 
brand attitude and purchase intention was supported $(\beta=0.815$; $t$-statistic $=26.793 ; p=0.033$ ); therefore, $\mathrm{H} 4$ is accepted.

\section{Conclusion}

Level of acceptance for Chinese brands is progressively growing in the recent market. As the brands offer better quality, cheaper price, good brand attitude, various products line, and advance innovation, they manage to enhance their popularity among international consumers. Product innovation adds more customers value, product origin extends positive brand attitude, and product knowledge is improved among consumers; thus, they all directly and indirectly influence purchase intention of Chinese brands. Since product knowledge has the lowest significance towards brand attitude and purchase intention, a company needs to focus on efforts to generate consumers' memory about product specifications. Promotion efforts through advertising and public relation are recommended because there are still few advertisements related to Chinese products which enhance product knowledge.

\section{Limitations}

This research also has some limitations. Firstly, it has geographical limitation. Secondly, it only has a small number of samples. Thirdly, few theoretical supports provide some limited space to explore this topic. Future studies can add more variables and implement this topic for different products. A comparison between two different lines of product is strongly recommended. As country of origin is one of the most significant variables in this research; hence, future research can compare different countries of origins. Further research can add more variables to determine causal relationship between brand attitude and purchase intention.

\section{References}

Abdillah, W., and J. Hartono. 2015. Partial Least Square (PLS). Yogyakarta: Andi.

Ajzen, I. 1991. 'The Theory of Planned Behaviour.' Organizational Behavior and Human Decision Processes 50 (2): 179-211.

Ajzen, I., and M. Fishbein. 2005. The Influence of Attitudes on Behaviour. Mahwah, NJ: Lawrence Erlbaum Associates.

Amine, L. S. 2008. 'Country of Origin, Animosity and Consumer Response: Marketing Implicatons of Anti-Americanism and Francophobia.' International Business Review 17:402-22. 
Anwar, S., S. Yasin, A. Iqbal, and M. Sajid. 2013. 'Country-of-Origin Impact on Brand Perception.' European Journal of Business 5 (8): 199-209.

Avkiran, N. K. 2018. 'An in-Depth Discussion and Illustration of Partial Least Squares Structural Equation Modeling in Health Care.' Health Care Management Science 21 (3): 401-8.

Bagozzi, R. P., and A. J. Silk. 1983. 'Recall, Recognition and the Measurement of Memory for Print Advertisements.' Marketing Science 2:95-134.

Barber, N., P. J. Kuo, M. Bishop, and R. Goodman, Jr. 2012. 'Measuring Psychographics to Assess Purchase Intention and Willingness to Pay' Journal of Consumer Marketing 29 (4): 280-92.

Beattie, A. E. 1982. 'Effects of Product Knowledge on Comparison, Memory, Evaluation and Choice: A Model of Expertise in Consumer DecisionMaking.' Advances in Consumer Research 9:336-341.

Beatty, S. E., and S. M. Smith. 1987. 'External Search Effort: An Investigation Across Several Product Categories.' Journal of Consumer Research 14 (1): 83-95.

Bhakar, S. S., and S. Bhakar. 2013. 'Relationship Between Country of Origin, Brand Image and Customer Purchase Intention.' Far East Journal of Psychology and Business 10 (2): 25-47.

Biehal, G., D. Stephens, and E. Curio. 1992. 'Attitude toward the Ad and Brand Choice.' Journal of Advertising 21 (3): 19-36.

Boyd, T. C., and H. M. Charlotte. 1999. 'The Link between Attractiveness of Extra Brand Attributes and the Adoption of Innovations.' Journal of the Academy of Marketing Science 27:306-19.

Brucks, M. 1985. 'The Effects of Product Class Knowledge on Information Search Behavior.' Journal of Consumer Research 12:1-16.

Cakici, N. M., and P. Shukla. 2017. 'Country-of-Origin Misclassification Awareness and Consumers' Behavioral Intentions: Moderating Roles of Consumer Affinity, Animosity and Product Knowledge.' International Marketing Review 34 (3): 354-76.

Chan, K., Y. L. Ng, and E. K. Luk. 2013. 'Impact of Celebrity Endorsement in Advertising on Brand Image among Chinese Adolescents.' Young Consumers 14 (2): 167-79.

Cheng, C. F., and Y. Y. Chang. 2008. 'Airline Brand Equity, Brand Preference and Purchase Intentions the Moderating Effects of Switching Costs. Journal of Air Transport Management 14:40-2.

Damanpour, F. 1991. 'Organizational Innovation: A Meta-Analysis of Effects of Determinants and Moderators.' The Academy of Management Journal 34 (3): 555-90.

Fan, Y. 2006. 'The globalization of Chinese Brands.' Marketing Intelligence \& Planning 24 (4): 365-79.

Fetscherin, M., and M. Sardy. 2008. 'Chinese Brands: The Build or Buy 
Considerations.' International Journal of Chinese Culture and Management 1:1-20.

Ghorban, Z. S. 2012. 'Brand Attitude, Its Antecedents and Consequences: Investigation into Smartphone Brands in Malaysia.' IOSR Journal of Business and Management 2 (3): 31-5.

Ghozali, I. 2008. Structural Equation Modeling Metode Alternatif Dengan Partial Least Square (PLS). 2nd ed. Semarang: Badan Penerbit Universitas.

Hair, J. F., W. C. Black, B. J. Babin, and R. E. Anderson. 2010. Multivariate Data Analysis. Upper Saddle River, NJ: Prentice Hall.

Hair, F. H., G. T. M. Hult, C. M. Ringle, and M. Sarstedt. 2014. A Primer on Partial Least Squares Structural Equation Modeling (PLS-SEM). Thousand Oaks, CA: Sage.

Hair, J. F., M. Sarstedt, and C. M. Ringle. 2017. Partial Least Squares Structural Equation Modeling in Handbook of Market Research. New York: Springer.

Hellier, P. K., G. M. Geursen, R. A. Carr, and J. A. Rickard. 2003. 'Customer Repurchase Intention: A General Structural Equation Model.' European Journal of Marketing 37 (11-12): 1762-8oo.

Holt, D. B., A. J. Quelch, and E. L. Taylor. 2004. 'How Consumers Value Global Brands.' Harvard Business Review 82 (9): 68-75.

Hsieh, M. H. 2004. 'An Investigation of Country-of-Origin Effect Using Correspondence Analysis, A Cross-National Context.' International Journal of Marketing Research 46 (3): 267-95.

James, L. R., and J. M. Brett. 1984. 'Mediators, Moderators, and Tests for Mediation.' Journal of Applied Psychology 69:307-21.

Juharsah and Hartini. 2014. 'The Role of Attitude as Relationship Mediation between Products Knowledge and Ethnocentrism on Purchasing Intention of Buton Special Woven (Study on the City of Bau-Bau)'. International Journal of Business and Management Invention 3 (11): 26-34.

Lee, L. 2013. 'The Relationship between Global Brand and Country of Origin in Chinese Consumption Market.' International Review of Business 13:87-112.

Lin, L. Y., and C. S. Chen. 2006. 'The Influence of the Country-of-Origin Image, Product Knowledge and Product Involvement on Consumer Purchase Decisions: An Empirical Study of Insurance and Catering Services in Taiwan. Journal of Consumer Marketing 23 (5): 248-65.

Lin, N. H., and B. H. Lin. 2007. 'The Effect of Brand Image and Product Knowledge on Purchase Intention Moderated by Price Discount.' Journal of International Management Studies, August, 121-32.

Lin, L., and J. Zhen. 2005. 'Extrinsic Product Performance Signaling, Product Knowledge and Customer Satisfaction: An Integrated Analysis - 
An Example of Notebook Consumer Behaviour in Taipei City.' Fu Jen Management Review 12 (1): 65-91.

Manning, K. C., W. O. Bearden, and T. J. Madden. 1995. 'Consumer Innovativeness and the Adoption Process.' Journal of Consumer Psychology 4 (4): 329-45.

Miniard, P. W., S. Bhatla, K. R. Lord, P. R. Dickson, and H. R. Unnava. 1991. 'Picture-Based Persuasion Processes and the Moderating Role of Involvement.' Journal of Consumer Research 27:92-107.

Mohr, J. J., and S. Sarin. 2009. 'Drucker's Insights on Market Orientation and Innovation: Implications for Emerging Areas in High-Technology Marketing.' Journal of the Academy of Marketing Science 37 (1): 85-96.

Oh, J. S., and D. Y. Jeong. 2015. 'The Effects of Consumers' Beliefs about T V Home Shopping Advertising on Attitude and Purchase Intention.' Indian Journal of Science and Technology 8 (14): 1-7.

Olson, J. C., and J. Jacoby. 1972. Cue Utilization in the Quality Perception Process. Iowa City, IA: Association for Consumer Research.

Ouellet, J. F. 2006. 'The Mixed Effects of Brand Innovativeness and Consumer Innovativeness on Attitude Towards the Brand.' Proceedings if the Annual Conference of the Administrative Sciences Association of Canada 27 (3): 310-24.

Park, C. W., and V. P. Lessig. 1981. 'Familiarity and Its Impact on Consumer Decision Biases and Heuristics.' Journal of Consumer Research 8:22330.

Percy, L., and J. R. Rossiter. 1992. 'A Model of Brand Awareness and Brand Attitude Advertising Strategies.' Psychology and Marketing 9 (4): 26374 .

Priester, J. R., D. Nayakankuppam, M. A. Fleming, and J. Godek. 2004. 'The A 2 SC2 Model: The Influence of Attitudes and Attitudes Strength on Consideration and Choice.' Journal of Consumer Research 30 (4): 57487.

Ramadania, S. Gunawan, and Jamaliah. 2013. 'Country of Origin Effect and Animosity on the Attitude and Purchase Intention of Foreign Products.' A SEAN Marketing Journal 5 (1): 59-68.

Ramadania, S. Gunawan, and M. Rustam. 2015. 'Cultural Similarity, Consumer Ethnocentrism and Product Necessity in Evaluation of Malaysian Products.' Procedia: Social and Behavioral Science 211:533-40.

Ramayah, T., J. W. C. Lee, and J. B. C. In. 2011. 'Network Collaboration and Performance in the Tourism Sector'. Service Business 5:411-28.

Sanchez, G. 2013. PLS Path Modeling with R. Berkeley, c A: Trowchez.

Seng, L. C., and Ping, N. S. 2016. 'The Influence of Product Innovation toward Consumer Purchase Intention.' International Journal of Economics, Commerce, and Management 4 (4): 773-82. 
Schooler, R. D. 1965. 'Product Bias in the Central American Common Market.' Journal of Marketing Research 2 (4): 394-97.

Shah, H., A. Aziz, A. R. Jaffari, S. Waris, W. Ejaz, M. Fatima, and K. Sherazi. 2012. 'The Impact of Brands on Consumer Purchase Intentions.' Asian Journal of Business Management 4 (2): 105-10.

Sheeraz, M., A. K. Khattak, M. Mahmood, and N. Iqbal. 2016. 'Mediation of Attitude toward Brand in the Relationship between Service Brand Credibility and Purchase Intentions.' Pakistan Journal of Commerce and Social Sciences 10 (1): 149-63.

Sicilia, M., S. Ruiz, and N. Reynolds. 2006. 'Attitude Formation Online: How the Consumer's Need for Cognition Affects the Relationship between Attitude towards the Website and Attitude towards the Brand.' International Journal of Market Research 48 (2): 139-54.

Somasundaram, T. N. 1993. 'Consumer Reaction to Product Failure: Impact of Product Involvement and Knowledge.' Advances in Consumer Research 20:215-8.

Suwatno, E. 2007. Metodologi Penelitian Kualitatif Dasar Teori dan Terapannya dalam Penelitian. Surakarta: Sebelas Maret University Press.

Taute, H. A., J. J. Sierra, L. L. Carter, and A. A. Maher. 2017. 'A Sequential Process of Brand Tribalism, Brand Pride and Brand Attitude to Explain Purchase Intention: A Cross-Continent Replication Study'. Journal of Product \& Brand Management 26 (3): 239-50.

Wong, K. K. 2013. 'Partial Least Square Equation Modeling (PLS-SEM) Technique Using SmartP Ls.' Marketing Bulletin 24 (1): 1-32.

Yasin, N. M., M. N. Noor, and O. Mohamad. 2007. 'Does Image of Countryof-Origin Matter to Brand Equity?' Journal of Product \& Brand Management 16 (1): 38-48.

This paper is published under the terms of the Attribution-

NonCommercial-NoDerivatives 4.o International (CC B Y-NC-ND 4.0)

License (http://creativecommons.org/licenses/by-nc-nd/4.o/). 


\title{
Macroeconomic Implications of Exchange Rate Depreciation: The Nigerian Experience
}

\author{
Ekundayo P. Mesagan \\ University of Lagos, Nigeria \\ profdayoms@yahoo.com \\ Olorunfemi Y. Alimi \\ University of Lagos, Nigeria \\ haleemphemy48o@gmail.com \\ Ismaila A. Yusuf \\ University of Lagos, Nigeria \\ ismailyusufakanni@yahoo.ca
}

This study examines the macroeconomic implications of exchange rate depreciation in Nigeria. It employs the Autoregressive Distributed Lag Bounds Testing Cointegration approach for data covering the period of 1970 to 2015. Empirical results confirm that the Naira depreciation positively and significantly impact all the indicators of macroeconomic performance except for output per capita, which is found to be insignificant. This implies that Naira depreciation stimulates trade balance; promotes price instability and increases the interest rate. Thus, currency depreciation does not benefit the country's economy. Moreover, the study confirms that long-run relationship exists between exchange rate depreciation and macroeconomic performance in Nigeria. Thus, there is the need for trade and export diversification to sustain gains from exchange rate movements and mitigate its negative effects on the economy.

Key Words: currency depreciation, output, inflation rate, interest rate, trade balance

JEL Classification: B 22, E31, E43, F31, O4O

https://doi.org/10.26493/1854-6935.16.235-258

\section{Introduction}

Exchange rate variations bring changes to trade balance and thus cause both price and output level of an economy to witness significant changes (Kandil 2004; Kollmann 2005; Mamun, Chowdhury, and Basher 2013; Cheung and Sengupta 2013). Nigeria's foreign sector is seriously affected by the depreciation of the naira against other major currencies of the world. Such has serious implication for Nigeria's macroeconomic performance. According to Ike (1984), Nigeria first witnessed depreciation in its 
currency by $10 \%$ in 1973 in response to the us currency depreciation the same year by the same amount. This made the country's foreign exchange reserves to grow by $773.5 \%$ in 1974 . Consequently, the effect of currency depreciation in the foregoing year was meagre in enhancing the foreign exchange asset position of the Nation as foreign exchange reserves fell by about $2.5 \%$. In 1974, it was observed that many other factors, like the increased oil export caused by the 1973 Arab-Israeli war and the increased oil price negotiated by the Organisation of Petroleum Exporting Countries (OPEC), contributed to the growth of Nigeria's foreign exchange reserves. More so, in November 2014, Nigeria depreciated its currency again by 28 per cent, from $\mathrm{N} 155$ to a dollar to $\mathrm{N} 197$, on the advice of the International Monetary Fund (IMF).

Exchange rate variations affect the economy via its exports channel in two ways - its depreciation and its volatility or risk (Fang, Lai, and Miller 2005). Both effects, have received considerable attention since fixed exchange rates system collapsed in the early 1970 . Depreciation has the tendency to lower the foreign currency price of exports, and perhaps boosts exports volume as well as export revenue in the home country. Export revenue can fall under certain conditions, like for instance; a very high inelastic foreign import demand translates to falling export revenue. According to Fang, Lai, and Miller (2005), it becomes ambiguous if export production incorporates high import content. This is because the domestic price of exports always rises with currency depreciation (Matsuyama, Kiyotaki, and Matsui 1993). Exchange from a hard or foreign currency to a local currency can result in either pass-through foreign exchange loss or gain. Realization of gains or losses depends on the appreciation or the depreciation of the local currency against respective hard currencies comparative to the date of the transaction that gave rise to earning of the hard currencies (Cherop and Changwony 2014).

Flexible, but stable exchange rates are critical to national and global economic well-being (Beckington and Amon 2011). Systematic exchange arrangements have the tendency to support and facilitate trade in goods and services and at the same time boost investments across national boundaries in a balanced and sustainable manner (Fang, Lai, and Miller 2005; Beckington and Amon 2011; Mengistu and Lee 2014). The essential logic behind these precepts is flawless, but accomplishing and maintaining such flexibility, stability, and order are hampered when national governments ignore these practical axioms for self-serving, short-sighted, and mercantilist reasons (Beckington and Amon 2011). In the short-term, 
a country's enforced undervaluation of its currency can be expected to boost its jobs, output, exports, and foreign reserves, while reducing imports and syphoning foreign direct investment along with research and development from other countries (Beckington and Amon 2011). Such 'beggar-thy-neighbour' gains, however, are contrary to the basic international goal of achieving efficient markets for the general welfare. They further run the risk of prompting other countries to misalign their own currencies in self-defence. At that point, the situation can deteriorate very quickly into destructively pervasive economic stagnation and worsen economic performance (Beckington and Amon 2011).

Theoretically, currency depreciation enhances economic performance as it allows domestic output level to rise promoting spending for home products (Mamun, Chowdhury, and Basher 2013). This is because it increases the competitiveness of exported goods in the international markets (Mengistu and Lee 2013; Nyeadi, Atiga, and Atogenzoya 2014). Conversely, it causes a higher level of import price, thereby engendering inflationary pressures especially in countries, like Nigeria, that is import dependent. Empirically, there is the ambiguity of evidence as to the type of effect exchange rate depreciation has on trade. Studies by Junz and Rhomberg (1973) and Wilson and Takacs (1979) suggested that devaluation enhances exports for developed economies that operate fixed exchange rates system, while Bahmani-Oskooee and Kara (2003) observed similar results for countries operating flexible exchange rates. However, Athukorala (1991), Athukorala and Menon (1994), Abeysinghe and Yeok (1998), Wilson and Tat (2001), and Fang, Lai, and Miller (2005) reported that depreciation does not improve export and trade performance of some Asian countries. Specifically, Fang, Lai, and Miller (2005) noted that exchange rate depreciation and exchange rate volatility generate a negative net effect on export growth and consequently adversely affects economic performance in the process.

Currency depreciation does not only weaken local firms' ability to transfer appropriate technology from foreign countries but also stalls industrial diversification in that it hurts agricultural export development. Currency depreciation has also been found to undermine the banks and hinders domestic ownership of private assets and economic performance (Fang, Lai, and Miller 2005; Fidelis 2014). The Marshal-Lerner condition states that depreciation brings a positive effect on trade when the sum of demand elasticities for exports and imports exceeds unity (Mengistu and Lee 2013). This means that depreciation improves trade balance if 
the depreciating nation's demand elasticity for imports plus the foreign demand elasticity for the country's exports exceed one. If this is not the case, then, currency depreciation could lead to economic contraction (Mamun, Chowdhury, and Basher 2013).

Since Nigeria currently faces depreciation of her currency which has seen a dollar been exchanged for over N36o officially, it becomes crucial to conduct a study of this sort. Moreover, since Nigeria is an import dependent country and it only depends on primary exports, which is demand inelastic in the international market, a study of this nature becomes inevitable. To this end, this study attempts to proffer answers to several questions such as: what sort of impact does Nigeria's currency depreciation have on the country's GDP? Does currency depreciation have any significant effect on improving Nigeria's trade balance? How does currency depreciation affect domestic price level? Does currency depreciation have anything to do with the domestic interest rate in the country?

The present study is at variance with previous studies as it focuses on the channel through which exchange rate depreciation affects the macro economy of Nigeria. Consequently, the main thrust of the study is to examine the macroeconomic effect of exchange rate depreciation in Nigeria between 1970 and 2015 .

The rest of the paper proceeds as follows: section two is on theoretical issues and review of past studies, section three presents analytical framework while section four focuses on data description and pre-estimation analyses. The fifth section presents the results and discussion of findings and section six conclude the paper.

\section{Literature Review}

THEORETICAL REVIEW

Interest Rate Parity (IRP) and Purchasing Power Parity (PPP)

The IRP states that the difference between interest rates in two countries is the difference between the future rate and the current rate of their currencies (Adrangi, Raffiee, and Shank 2007; Cherop and Changwony 2014; Lo and Morley 2015). The theory states that real interest rates should be equalized across countries under fully liberalized financial markets without government interventions and capital controls (Chang and Su 2015). If this parity is broken, then there is the existence of an arbitrage resulting in a risk-free return (Edison 1987). According to this theory, if an investor makes his own forecasts by using rational expectations and, at the same time, the international capital markets and the product markets are in- 
tegrated well enough, then real interest rates must be equal across countries (Chang and Su 2015). P P P in its own sense is a theory of long term equilibrium exchange rates based on relative price levels of two countries (Cherop and Changwony 2014). According to He, Ranjbar, and Chang (2013), P P P remains a cornerstone of many theoretical models in international finance. The P P P states that the exchange rates between two currencies are in equilibrium when the purchasing power is the same in both countries. This implies that the exchange rate between any two countries should equal the ratio of the two currencies' price level of a fixed basket of goods and services. The basic idea behind the PPP hypothesis is that because any international goods market arbitrage should be traded away over time, we should expect the real exchange rate to return to a constant equilibrium value in the long run (He, Ranjbar, and Chang 2013). The concept is founded on the law of one price which states that in the absence of transaction costs, identical goods will have the same price in different markets (Cherop and Changwony 2014).

\section{Exchange Rate Channel of Monetary Transmission}

In recent empirical studies on monetary policy transmission, attention has been directed towards exchange rate channels of monetary transmission. This becomes very crucial as the exchange rate channel has a significant role to play in aggregate output fluctuations in an economy. The exchange rate channel plays an important role in how monetary policy affects the domestic performance of an economy (Taylor 1993; 1995; Mishkin 1996). The channel works through the interest rate effects. This is so because when real domestic interest rates decrease, domestic currency deposits (for instance, Naira) become less attractive to foreign investors relative to deposits that are foreign denominated (like us dollar), leading to a decline in the value of the domestic currency deposits relative to other foreign currency deposits (Mishkin 1996). This means a depreciation of the domestic currency relative to other foreign currencies and the implication of this on aggregate output is that it makes domestic goods produced in the country cheaper compared to foreign goods thereby making exports of domestic goods increase sharply relative to imports. Consequently, net exports rise, and aggregate domestic outputs rise as well.

\section{EMPIRICAL REVIEW}

There are series of studies on exchange rate, trade and output performance for developing countries, as well as, exchange rate and export per- 
formance. Result wise, some studies agreed that exchange rate depreciation stimulate output growth and trade balance while others found negative results. For instance, Devarajan, Lewis, and Robinson (1993) observed that exchange rate depreciation enhanced economic performance. Cherop and Changwony (2014) opined that domestic currency depreciation stimulates economic activity through the initial increase in the price of foreign goods relative to the price at home. Hence, by increasing the international competitiveness of domestic industries, exchange rate depreciation diverts spending from foreign goods to domestic goods. Similar conclusions were arrived at in Guitian (1976), Dornbusch (1988), Beckington and Amon (2011), as well as, Mengistu and Lee (2014). For Frankel (1998), the success of currency depreciation in facilitating trade balance mainly depends on switching demand in the proper direction and on the capacity of the home economy to meet the additional demand by supplying more goods.

For cross-country studies, Fang, Lai, and Miller (2005) researched into export promotion through exchange rate policy in Indonesia, Thailand, Japan, Taiwan, Singapore, Philippines, Korea and Malaysia. It was affirmed that exchange rate movements affect exports through its depreciation and its variability (risk). Depreciation, as suggested, raises exports, but exchange rate risk could offset that positive effect. The net effect between both effects was investigated for the selected countries and result showed that depreciation enhanced export. Exchange rate risk contributed to export growth in Malaysia and the Philippines, leading to positive net effects. It also produced a negative effect for six of the countries, resulting in a negative net effect in Indonesia, Japan, Singapore, Taiwan and a zero-net effect in Korea and Thailand. Ali and Anwar (2011) examined the repercussions of induced currency depreciation in developing countries. The results presented were based on a model with firm microeconomic foundations and which takes into cognizance both the supply and demand-side effects of exchange rate variations. The distinctive feature of the model is the role of exchange rate expectations. The study considered three kinds of expectations; adaptive, extrapolative, and regressive expectations. Several sensitivity tests were also performed based on these expectations. Based on simulation, it was reported that the effect of induced currency depreciation largely depends on supply-side effects and that in most cases, currency depreciation results in a fall in output, a price increase and an improvement in the trade balance. The study reported that in the absence of weak supply-side effects of exchange rates, if 
the Marshall-Lerner conditions hold, then home currency depreciation will have a favourable effect on output and a negative effect on trade balance.

Furthermore, Nouira, Plane, and Sekkat (2011) researched into exchange rate devaluation and manufactured export. It employed a sample of 52 developing countries, which has adopted proactive exchange rate policies and the results showed that between 1991 and 2005, several countries used undervaluation to foster the price competitiveness of manufactured exports. Mengistu and Lee (2014) investigated the effects of currency depreciation on the trade balance in selected fourteen Asian economies. The findings did not find any evidence for depreciation enhancing trade balance in the selected sample. However, when the study was narrowed down to eight relatively bigger, stable and more industrialised countries, depreciation enhanced trade balance. Hooy, Law, and Chan (2015) examined the impact of the real exchange rate on ASEAN disaggregated exports to China. First, the study found that income elasticity is positive and significant in all export categories and increases with higher technology products. Secondly, they found that the R M B real exchange rate significantly and positively enhanced ASEAN total exports to China. Thirdly, the R M B effect on disaggregated exports by technology level is mixed; for finished goods exports, higher technology exports were more sensitive to R $\mathrm{MB}$ depreciation, which is consistent with the income effect, while for parts and components exports, the lower technology exports had greater exposure to RM B depreciation, which is possibly due to the price effect and the recent production relocations of multinational corporations in the ASEAN region to China and Vietnam.

For country specific studies, Cheung and Sengupta (2013) looked at the effect of exchange rate movements on exports of Indian non-financial sector firms between 2000 and 2010. Results revealed that exports shares of Indian firms were negatively but significantly impacted by currency appreciation. The Indian firms with smaller export shares responded strongly to real exchange rate volatility, compared with those exporting goods. Also, firms that export services were more affected by exchange rate fluctuations. Similarly, Divakaran and Gireeshkumar (2014) focused on the Indian economy and found that a weak rupee made India produce more competitively in global markets, thereby stimulating the country's exports and output growth. More so, focusing on the same India, and using 36 currency trade-based effective nominal and real exchange rates and trade balance, Datta (2014) observed that increase of trade balance in 
India is an important reason for currency depreciation. Mamun, Chowdhury, and Basher (2013) examined the effect of exchange rate variation on domestic output growth and price level of Bangladesh. Combining exchange rate and other traditional factors like investment, bank credit, narrow and broad money together with the labour force, the study observed that depreciation has an expansionary effect on output and price level. $\mathrm{Li}, \mathrm{Ma}$, and $\mathrm{Xu}$ (2015) focused on the exchange rate and export in China by proving first-hand firm-level evidence on Chinese exporters' reaction to R $\mathrm{MB}$ exchange rate movements. It was reported that exporters with higher productivity price responded more to exchange rate movements. Furthermore, R м в appreciation reduced the probability of entry as well as the probability of continuing in the export market. Paudel and Burke (2015) extended the study to Nepal between 1980 and 2010. Employing a gravity modelling approach, it confirmed that real exchange rate appreciation influenced Nepal's export.

For some notable African studies, Nyeadi, Atiga, and Atogenzoya (2014) analysed the impact of exchange rate movement on export growth in Ghana from 1990 to 2012 . The study observed that exchange rate has no impact on Ghana's export but that output, national saving, import growth and total investment significantly impact export. Cherop and Changwony (2014) conducted a survey on exchange rate fluctuation and tea export earnings among smallholder tea factories in Kenya using correlation analysis. Results found a positive relationship between exchange rate and per kilogram of green leaf paid. It also observed positive correlation between exchange rate and quantities of tea sold. Extending the study to Nigeria, Loto (2011) adopted the elasticity approach to the balance of payment adjustment. The result showed that depreciation did not improve trade balance and that Marshal-Lerner condition did not hold for Nigeria. Ogbonna (2011) tested the Marshall-Lerner (ML) condition for Nigeria using data between 1970 and 2005. The study found no long run relationship between trade balance and real exchange rate but confirmed that Marshall-Learner $(\mathrm{ML})$ condition holds and that depreciation enhanced trade balance in the country. Ogundipe and Egbetokun (2013) employed data covering 1970 to 2010 and found that exchange rate induced an inelastic and significant impact on the trade balance in the long run while no causality was found in the short run. Umoru and Oseme (2013) explored the J-curve effect in studying trade flows and exchange rate shocks in Nigeria. The study did not find any empirical evidence in favour of the short-run deterioration of the trade balance as implied by 
the J-curve hypothesis but found evidence for the cyclical trade effect of exchange rate shocks. Adediran, Yusuf, and Adeyemi (2014) traced exchange rate fluctuation to output growth Nigeria between 1986 and 2013 and found that exchange rate depreciation positively but insignificantly impacted the GDP.

Considering the review so far, previous studies have beamed searchlight on the subject matter in several ways. Studies such as; Guitian (1976), Dornbusch (1988), Devarajan, Lewis, and Robinson (1993), Fang, Lai, and Miller (2005), Ali and Anwar (2011), Beckington and Amon, (2011), Mengistu and Lee (2014), as well as Cherop and Changwony (2014), have focused on the link between exchange rate and output growth. Others, like Cheung and Sengupta (2013), Datta (2014), Paudel and Burke (2015), and Hooy, Law, and Chan (2015), have focused on the nexus between exchange rate and trade balance or export. However, there is a dearth of studies focusing on the implications of exchange rate depreciation on macroeconomic performance. The present study aims to fill this noticeable gap in the literature.

Also, since there has been no consensus in the literature on the exact effect of exchange rate depreciation on variables like export, trade balance, and output growth, this study attempts to further deepen the discussion and take a position. Moreover, the recent happenings in Nigeria, where exchange rate movements have thrown the country into recession, and the fact that studies like; Loto (2011), Ogbonna (2011), Ogundipe and Egbetokun (2013), Umoru and Oseme (2013), and Adediran, Yusuf, and Adeyemi (2014) did not account for exchange rate effect on macroeconomic indicators like the interest rate, provides justification for this study.

\section{Analytical Framework}

This empirical investigation looks at currency depreciation and macroeconomic performance in Nigeria over the period 1970-2015. Sequel to the literature review on exchange rate depreciation and following the work of Ali and Anwar (2011), the empirical model is specified thus:

$$
\pi_{1}=E_{t} \pi_{t+1}+b_{1} y_{t}+b_{2} p_{t}+b_{3}\left(p^{f}+e_{t}\right)+u_{1} .
$$

Equation (1) is derived by making use of the New Keynesian Approach and it represents the supply side of the market. In equation (1), $\pi_{t}$ is the inflation rate, $E_{t} \pi_{t+1}$ is expected inflation rate, $y_{t}$ is the current period output, $p_{t}$ is the domestic price level, $p^{f}$ is foreign price level, $e_{t}$ is nominal 
exchange rate, $b_{1}, b_{2}$ and $b_{3}$ are the slope parameters for output, domestic price level, and foreign price level respectively, and $u_{1 t}$ is the residual term. As affirmed in Ali and Anwar (2011), equation (1) is an expectationsaugmented Philips curve for an open economy where the exchange rate is found to not only affects directly the domestic inflation rate but also its stabilizing properties (Froyen and Guender 2000; Ali and Anwar 2011). In equation (1), it is expected that exchange rate depreciation leads to higher inflation, while an appreciation leads to deflation in the home country.

On the supply-side, depreciating the home currency can cause unfavourable effects in the home economy (in the form of higher inflation and lower output). Alternatively, the model can be expanded by introducing exchange rate on the supply side as we have in Ball (1999), Froyen and Guender (2000), and Ali and Anwar (2010; 2011).

$$
y_{t}=E_{t} y_{t+1}-a_{1}\left(r_{t}-r_{t}^{f}\right)+a_{2}\left(p_{t}^{f}+e_{t}\right)+u_{2 t} .
$$

Equation (2) is the Is curve known as expectational or inter-temporal Is equation showing that the demand for output in the current period depends on expected output. In equation (2), $y_{t}$ is current period output, $E_{t} y_{t+1}$ is the expected output, $r_{t}-r_{t}^{f}$ is the interest rate differential, $a_{1}$ and $a_{2}$ are slope parameters for real interest rate and price level respectively, $p_{t}^{f}$ is foreign price level, $e_{t}$ is nominal exchange rate while $u_{2 t}$ is the residual term. A similar is curve, with firmer micro economic foundations than the traditional is curve, has been employed in Kerr and King (1996), McCallum and Nelson (1999) and Ali and Anwar (2011).

$$
i_{t}=i^{f}+\bar{e}_{t+1}-e_{t}+u_{3 t} \text {. }
$$

Equation (3) is the interest parity condition. In equation (3), $i_{t}$ is the nominal interest rate, $i^{f}$ is the foreign interest rate, $\bar{e}_{t+1}$ is the expected nominal exchange rate, $e_{t}$ is nominal exchange rate, and $u_{3} t$ is the residual term. Interest parity states that due to arbitrage by risk neutral agents, the domestic interest rate will be equal to the foreign interest rate plus expected capital gains that are associated with holding wealth in foreign currency denominated assets.

$$
r_{t}=i_{t}-E_{t} \pi_{t+1} \text {. }
$$

Equation (4) is the real interest rate and it is defined as the nominal interest rate minus the expected inflation rate. In equation (4), $r_{t}$ is the real interest rate, $i_{t}$ is nominal interest rate, and $E_{t} \pi_{t+1}$ is expected inflation rate. 
The ARDL bounds test developed by Pesaran, Shin, and Richard (2001) is employed to estimate the links owing to its superior small sample performance. This procedure is built on the $F$-statistic or Wald test in a generalized Dickey-Fuller type of regression normally used to test the significance of lagged levels of those variables that are under consideration in a conditional unrestricted equilibrium error correction model (Pesaran, Shin, and Richard 2001). The ARDL bounds test also helps to analyse the long-run relationships and short run dynamic interactions among variables in the study.

The proposed tests are based on standard $F$ - and $t$-statistics used to test the significance of the lagged levels of the variables in a first difference regression. The test is applicable irrespective of whether the underlying regressors are I(o), I(1) or mutually integrated. It entails the estimation of the unrestricted error correction model (U ECM) specified in equation (5) following Pesaran, Shin, and Richard (2001).

$$
V Y_{t}=\alpha_{\mathrm{o}}+\sum_{i=1}^{p} \alpha_{1} V Y_{t-1}+\sum_{i=1}^{p} \alpha_{2} V Y_{t-i}+\beta_{1} Y_{t-1}+\beta_{2} Z_{t-1}+\varepsilon_{1}
$$

where $Y_{t}$ is the vector of dependent variables, $Z_{t}$ is the vector of explanatory variables, $V$ is the difference operator, $P$ is the lag structure, $\alpha_{1}$ and $\alpha_{2}$ are the short run coefficients, $\beta_{1}$ and $\beta_{2}$ are the long run coefficients, while $\varepsilon_{1 t}$ are the residual terms. The null hypothesis of no long run equilibrium relationship will be tested (i.e. $\mathrm{H}_{\mathrm{o}}: \beta_{1}=\beta_{2}=\mathrm{o}$ ) against the alternative hypothesis of the existence of long run relationships (i.e. $\mathrm{H}: \beta_{1} \neq \beta_{1}$ $\neq 0$ ) using the $F$-test as suggested in Pesaran, Shin, and Richard (2001). However, this test has nonstandard distributions depending on the sample size, the inclusion of intercept and trend variable in the equation, as well as the number of regressors.

The estimated ARDL test statistics will be compared with two asymptotic critical values reported in Pesaran, Shin, and Richard (2001) as against the conventional critical values. If the test statistic is above an upper critical value, it implies that the null hypothesis of no long-run relationship is rejected, but if it is below a lower critical value, the null hypothesis will be accepted. If it, however, falls between these two bounds or critical values, the result is declared inconclusive.

Hence, following Pesaran, Shin, and Richard (2001), the models estimated are specified in equations (6) to (9) as follows: 


$$
\begin{aligned}
& \Delta \operatorname{lnGDP}_{t}=\beta_{\mathrm{O}}+\beta_{1} \operatorname{lnGDP}_{t-1}+\beta_{2} \operatorname{lnHC}_{t-1}+\beta_{3} \ln \ln _{t-1} \\
& +\beta_{4} \ln \mathrm{no}_{t-1}+\beta_{5} \operatorname{lnINV}_{t-1} \\
& +\sum_{i=1}^{p} \theta_{1} \Delta \operatorname{lngDP}_{t-1}+\sum_{i=1}^{p} \theta_{2} \Delta \operatorname{lnnC}_{t-1}+\sum_{i=1}^{p} \theta_{3} \Delta \ln \mathrm{Ex}_{t-1} \\
& +\sum_{i=1}^{p} \theta_{4} \Delta \ln \mathrm{TO}_{t-1}+\sum_{i=1}^{p} \theta_{5} \Delta \operatorname{lnnNv}_{t-1}+\varepsilon_{1}, \\
& \Delta \operatorname{lnINF}{ }_{t}=\phi_{\mathrm{O}}+\phi_{1} \Delta \operatorname{lnINF}_{t-1}+\phi_{2} \Delta \ln \mathrm{nX}_{t-1}+\phi_{3} \Delta \ln _{\mathrm{TO}} \mathrm{O}_{t-1} \\
& +\phi_{4} \Delta \operatorname{lnMs}_{t-1}+\phi_{5} \Delta \operatorname{lngDP}_{t-1} \\
& +\sum_{i=1}^{p} \delta_{1} \Delta \operatorname{lnINF}_{t-1}+\sum_{i=1}^{p} \delta_{2} \Delta \ln \ln _{t-1}+\sum_{i=1}^{p} \delta_{3} \Delta \ln \mathrm{To}_{t-1} \\
& +\sum_{i=1}^{p} \delta_{4} \Delta \operatorname{lnMs}_{t-1}+\sum_{i=1}^{p} \delta_{5}+\Delta \operatorname{lngDP}_{t-1}+\varepsilon_{2 t}, \\
& \Delta \operatorname{lnINT} t=\vartheta_{o}+\vartheta_{1} \operatorname{lnINT}_{t-1}+\vartheta_{2} \operatorname{lnEx}_{t-1}+\vartheta_{3} \ln \mathrm{LO}_{t-1} \\
& +\vartheta_{4} \operatorname{lnINV}_{t-1}+\vartheta_{5} \operatorname{lnMs}_{t-1} \\
& +\sum_{i=1}^{p} \gamma_{1} \operatorname{lnINT}_{t-1}+\sum_{i=1}^{p} \gamma_{2} \ln \mathrm{Ex}_{t-1}+\sum_{i=1}^{p} \gamma_{3} \ln \mathrm{TO}_{t-1} \\
& +\sum_{i=1}^{p} \gamma_{4} \operatorname{lnINv}_{t-1}+\sum_{i=1}^{p} \gamma_{5} \operatorname{lnMs}_{t-1}+\varepsilon_{3 t} \\
& \Delta \operatorname{lnTB}_{t}=\alpha_{\mathrm{o}}+\alpha_{1} \operatorname{lnTB}_{t-1}+\alpha_{2} \operatorname{lnEx}_{t-1}+\alpha_{3} \ln \mathrm{TO}_{t-1} \\
& +\alpha_{4} \operatorname{lnINV}_{t-1}+\alpha_{5} \operatorname{lnGDP}_{t-1} \\
& +\sum_{i=1}^{p} \omega_{1} \ln \mathrm{TB}_{t-1}+\sum_{i=1}^{p} \omega_{2} \ln \mathrm{Ex}_{t-1}+\sum_{i=1}^{p} \omega_{3} \ln \mathrm{TO}_{t-1} \\
& +\sum_{i=1}^{p} \omega_{4} \operatorname{lnINv}_{t-1}+\sum_{i=1}^{p} \omega_{5} \operatorname{lnGDP}_{t-1}+\varepsilon_{4 t},
\end{aligned}
$$

where $\Delta$ is the first difference operator, $\beta_{1-5}, \phi_{1-5}, \vartheta_{1-5}$, and $\alpha_{1-5}$ are longrun multipliers corresponding to long-run relationships, $\beta_{0}, \phi_{0}, \vartheta_{0}$, and $\alpha_{\mathrm{o}}$ are drifts, $\theta_{1-5}, \delta_{1-5}, \gamma_{1-5}$, and $\omega_{1-5}$ are the short run dynamic coefficients of the underlying ARDL model in the equation; $t$ is a time or trend variable, and $\varepsilon_{1-4}$ are white noise errors. The dependent variables are variables used to proxy macroeconomic performance such as trade balance per capita (тв) captured by net export per capita, economic growth 
TAB LE 1 List of Variables and Descriptive Statistics

\begin{tabular}{lllrrrr}
\hline$(1)$ & $(2)$ & $(3)$ & $(4)$ & $(5)$ & $(6)$ & $(7)$ \\
\hline GDP & GDP per capita & US\$ (constant 2010) & 1698.35 & 419.07 & 2548.43 & 1147.75 \\
T B & Trade bal. per capita & US\$ (constant 2010) & 155.47 & 141.75 & 436.22 & - \\
& & & & & & 133.33 \\
INF & Inflation rate & CPI $(2010=100)$ & 18.65 & 16.24 & 72.84 & 3.46 \\
INT & Mon. policy rate & Rate (\%) & 10.89 & 5.11 & 26.00 & 3.50 \\
EX & Exchange rate & US\$ = N & 54.58 & 65.24 & 193.28 & 0.546 \\
INV & Investment & GFCF as \% of GDP & 14.67 & 7.28 & 35.22 & 5.46 \\
HC & Enrolment rate & Secondary (both sexes) & 24.62 & 11.99 & 43.84 & 4.41 \\
TO & Trade openness & Trade as \% of GDP & 47.69 & 16.44 & 81.81 & 19.62 \\
MS & Financial deepening & M2 as \% of GDP & 22.51 & 7.17 & 43.27 & 10.04 \\
\hline
\end{tabular}

Notes Column headings are as follows: (1) Variables, (2) descriptive, (3) measurement unit, (4) mean, (5) standard deviation, (6) maximum, (7) minimum.

captured by real gross domestic product per capita (GDP), inflation rate captured by consumer price index (INF) and interest rate measured by monetary policy rate (INT). The explanatory variables include exchange rate (EX), and other controlled variables like investment (INV), proxied with gross fixed capital formation (GFCF), human capital (HC), which is proxied with secondary school enrolment rate, trade openness (то) proxied with total trade as a ratio of real GDP and money supply captured by the ratio of money supply to real GDP (MS). It is expected that exchange rate depreciation will positively impact trade balance as export is expected to be boosted, positively enhancing output, negatively impacting inflation, due to imported inflation for Nigeria and raising the interest rate to curtail the inflation.

\section{Data Description and Pre-Estimation Tests}

This study used annual time series data spanning from 1970 to 2015. The data were extracted from the World Development Indicator (see http://wdi.worldbank.org) and the Central Bank of Nigeria Annual Statistical Bulletin (see https://www.cbn.gov.ng/documents/statbulletin.asp). Table 1 presents the descriptive statistics of the indicators. The average growth rate of the macroeconomic performance variables revealed US $\$ 1,698.35$, U $\$ 155.47,18.65 \%$ and $10.89 \%$ for GDP per capita, trade balance per capita, inflation rate and interest rate respectively. The mean value of exchange rate and secondary school enrolment stood at N54.58 


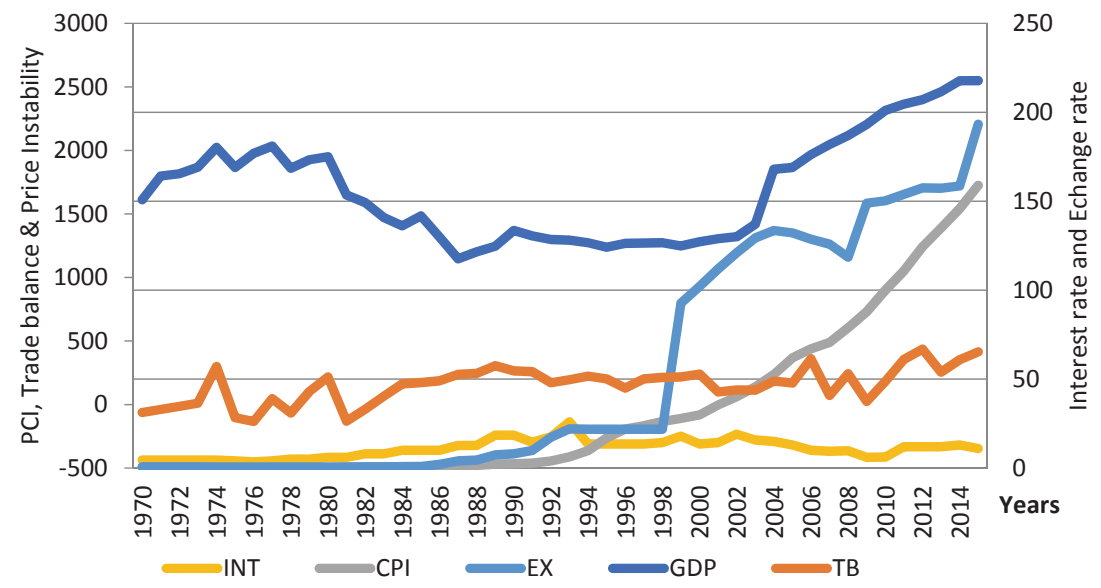

FIgURE 1 Exchange Rate and Macroeconomic Performance

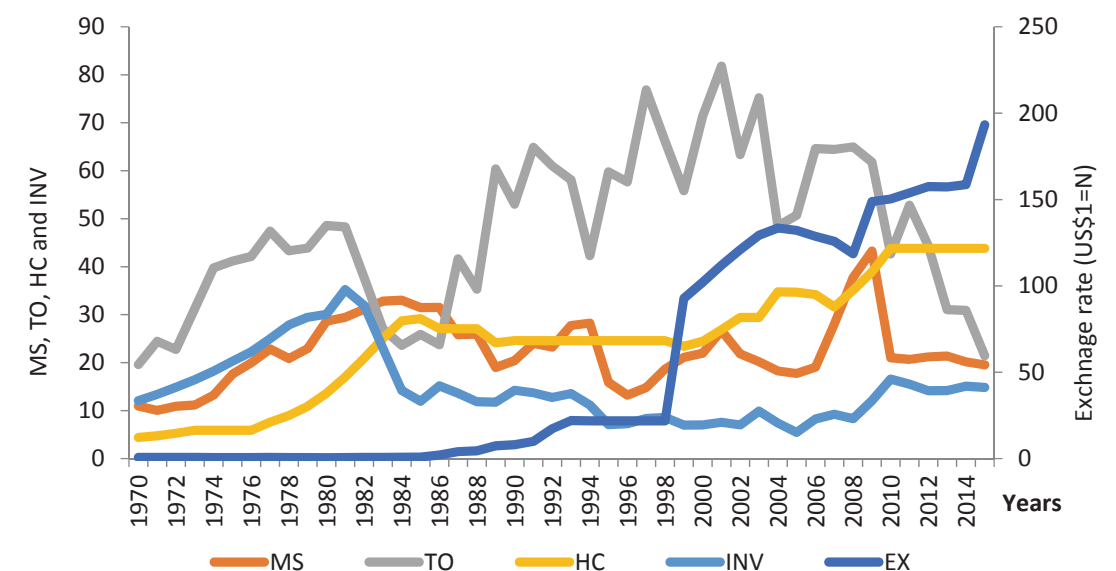

Figure 2 Exchange Rate, Money Supply, Trade Openness, Human Capital, and Investment

to a us dollar and $24.62 \%$ respectively within the considered periods. For other explanatory indicators, the average values of investment, total trade and money supply to the size of the Nigerian economy were $14.67 \%$, $47.69 \%$ and $22.51 \%$ correspondingly.

The graphical illustrations of our variables are depicted in figures 1 and 2. Figure 1 shows the trend analysis of exchange rate and macroeconomic performance such as per capita income, trade balance, price instability and interest rate. Trend movement of the exchange rate and other explanatory variables like financial deepening, trade openness, human cap- 
TABLE 2 Correlation Matrix

\begin{tabular}{|c|c|c|c|c|c|c|c|c|c|}
\hline & GDP & T B & INF & INT & $\mathrm{EX}$ & MS & TO & $\mathrm{HC}$ & INV \\
\hline GDP & 1 & & & & & & & & \\
\hline T B & 0.115 & 1 & & & & & & & \\
\hline INF & -0.403 & -0.002 & 1 & & & & & & \\
\hline INT & -0.482 & 0.532 & 0.331 & 1 & & & & & \\
\hline EX & 0.555 & 0.465 & -0.291 & 0.243 & 1 & & & & \\
\hline INV & -0.038 & 0.014 & 0.003 & 0.064 & 0.080 & 1 & & & \\
\hline $\mathrm{HC}$ & -0.304 & 0.166 & 0.116 & 0.494 & 0.258 & 0.092 & 1 & & \\
\hline TO & 0.278 & 0.669 & -0.090 & 0.476 & 0.796 & 0.356 & 0.201 & 1 & \\
\hline MS & 0.267 & -0.431 & -0.099 & -0.567 & -0.423 & 0.193 & -0.378 & -0.421 & 1 \\
\hline
\end{tabular}

TABLE 3 ADF Unit Root Tests for the Variables at Levels and First Differences

\begin{tabular}{|c|c|c|c|c|c|}
\hline \multirow[t]{2}{*}{ Variables } & \multicolumn{2}{|c|}{ Levels } & \multicolumn{2}{|c|}{ First difference } & \multirow[t]{2}{*}{ Results } \\
\hline & No trend & Trend & No trend & Trend & \\
\hline GDP & 0.2521 & -0.2053 & $-5.9050^{* *}$ & $-6.5328^{\star *}$ & $\mathrm{I}(1)$ \\
\hline тв & $-3.6708^{* *}$ & $-5.1622^{\star *}$ & - & - & $\mathrm{I}(\mathrm{o})$ \\
\hline INF & $-3.2838^{\star}$ & -3.2934 & $-6.8328^{\star *}$ & $-6.8010^{* *}$ & $\mathrm{I}(1)$ \\
\hline INT & -2.3267 & -2.3738 & $-7.2042^{* *}$ & $-7.2501^{* *}$ & $\mathrm{I}(1)$ \\
\hline EX & 0.9479 & -1.5310 & $-5.7889^{* *}$ & $-6.1582^{\star *}$ & $\mathrm{I}(1)$ \\
\hline INV & $-4.6314^{\star *}$ & $-5.7012^{\star *}$ & - & - & $\mathrm{I}(\mathrm{o})$ \\
\hline $\mathrm{HC}$ & -1.0342 & -2.2190 & $-4.2636^{* *}$ & $-4.2158^{\star *}$ & $\mathrm{I}(1)$ \\
\hline то & -2.4497 & -2.0148 & $-7.9537^{* *}$ & $-8.3016^{* *}$ & $\mathrm{I}(1)$ \\
\hline MS & $-3.3666^{*}$ & $-3.5246^{* *}$ & - & - & $\mathrm{I}(\mathrm{o})$ \\
\hline
\end{tabular}

NOTES ${ }^{* *}$ and ${ }^{\star}$ denotes significance level at $1 \%$ and $5 \%$ respectively.

ital and investment are shown in figure 2. The trend reviews of the figures do not show clear direction (whether positive or negative) of all the macroeconomic indicators with the exchange rate. The inconclusiveness of the direction of our variables necessitates the need for an empirical analysis.

Table 2 shows the results of the correlation coefficients indicating that the problem of multicollinearity has been checked for our autoregressive distributed lag (ARDL) outputs. The first pre-estimation test conducted was to establish the order of integration of all indicators as they are critical to the estimation because estimating a time series model with non- 
TABLE 4 Result of ARDL Bounds Test for Cointegration Relationship

\begin{tabular}{|c|c|c|c|c|c|c|}
\hline \multicolumn{2}{|l|}{ Dependent variables } & \multicolumn{3}{|c|}{ Functions } & \multicolumn{2}{|c|}{$F$-statistics } \\
\hline \multicolumn{2}{|c|}{ GDP Model ARDL $(4,1,3,4,4)$} & \multicolumn{3}{|c|}{$F_{\mathrm{GDP}}(\mathrm{GDP} \mid \mathrm{HC}, \mathrm{EX}, \mathrm{TO}, \mathrm{INV})$} & \multicolumn{2}{|c|}{$4.0483^{* *}$} \\
\hline \multicolumn{2}{|c|}{ Price instability Model ARDL $(4,4,3,4,3)$} & \multicolumn{3}{|c|}{$F_{\text {INF }}(\mathrm{INF} \mid \mathrm{EX}, \mathrm{TO}, \mathrm{MS}, \mathrm{GDP})$} & \multicolumn{2}{|c|}{$6.6905^{* * *}$} \\
\hline \multicolumn{2}{|c|}{ Interest rate Model A RDL $(1,4,0,4,2)$} & \multicolumn{3}{|c|}{$F_{\text {INT }}(\mathrm{INT} \mid \mathrm{EX}, \mathrm{TO}, \mathrm{INV}, \mathrm{MS})$} & \multicolumn{2}{|c|}{$4.4786^{\star *}$} \\
\hline \multicolumn{2}{|c|}{ Trade balance Model ARDL $(2,0,1,0,1)$} & \multicolumn{3}{|c|}{$F_{\mathrm{TB}}(\mathrm{TB} \mid \mathrm{EX}, \mathrm{TO}, \mathrm{INV}, \mathrm{GDP})$} & \multicolumn{2}{|c|}{$8.5002^{* * *}$} \\
\hline & \multicolumn{2}{|l|}{$1 \%$} & \multicolumn{2}{|c|}{$5 \%$} & \multicolumn{2}{|c|}{$10 \%$} \\
\hline & $\mathrm{I}(\mathrm{o})$ & $\mathrm{I}(1)$ & $\mathrm{I}(\mathrm{o})$ & $\mathrm{I}(1)$ & $\mathrm{I}(\mathrm{o})$ & $\mathrm{I}(1)$ \\
\hline Critical bound values & 3.74 & 5.06 & 2.86 & 4.01 & 2.45 & 3.52 \\
\hline
\end{tabular}

NOTES ${ }^{* *},{ }^{* *}$, and ${ }^{\star}$ denote rejection of null hypothesis at $1 \%, 5 \%$ and $10 \%$ significance levels respectively.

stationary regressors could lead to spurious regression. This study used the Augmented Dickey Fuller (A DF) test by Dickey and Fuller (1979) to ascertain the stationarity level of all variables. The unit root result suggests that all the variables are of order one except trade balance, investment and money supply which are found to be integrated of order zero. The results of the unit root tests are presented in table 3 .

The result from the integration test confirmed the appropriateness of the chosen estimation technique (ARDL). Moreover, the results of the ARDL bounds tests for cointegration are presented in Table 4. The Akaike Info Criterion (AIC) was used to select the orders of the ARDL models.

The result revealed that the computed $F$-statistics are greater than the upper bound critical values indicating that the null hypotheses of no cointegration are rejected at $5 \%$ significance level. This implies that there is satisfactory evidence in support of a unique and stable long-run relationship between currency depreciation and macroeconomic performance in Nigeria.

\section{Empirical Results and Discussion}

Tables 5 and 6 present both the long-run estimates and the diagnostic and stability tests respectively. Models 1-4 revealed the A RDL models for output growth, price instability, interest rate and trade balance correspondingly. Table 5 shows that naira depreciation has a positive and significant impact on all the indicators of macroeconomic performance considered within the periods except for output per capita which was found insignificant at $5 \%$ significance level. In magnitude terms, a $10 \%$ change in depreciation of Naira would positively increase output per capita, inflation 
TABLE 5 Results of the Estimated ARDL Long-Run Coefficients

\begin{tabular}{|c|c|c|c|c|}
\hline \multirow{2}{*}{$\begin{array}{l}\text { Independent } \\
\text { variables }\end{array}$} & \multicolumn{4}{|c|}{ Dependent variables } \\
\hline & (1) & (2) & (3) & (4) \\
\hline Constant & $12.335(2.904)^{* * *}$ & $-1.529(3.630)$ & $-3.267(1.947)$ & $6.354(1.670)^{* *}$ \\
\hline $\mathrm{HC}$ & $0.081(0.208)$ & & & \\
\hline $\mathrm{EX}$ & $0.061(0.087)$ & $0.108(0.004)^{\star *}$ & $0.200(0.058)^{\star * *}$ & $+1.437(0.312)^{\star * \star}$ \\
\hline то & $-0.101(0.045)^{\star *}$ & $0.084(0.283)^{\star}$ & $0.707(0.279)^{\star *}$ & $-0.381(0.143)^{\star \star}$ \\
\hline INV & $-0.054(0.061)$ & & $0.932(0.395)^{\star *}$ & $0.233(0.153)$ \\
\hline MS & & $0.300(0.239)$ & $-0.076(0.287)$ & \\
\hline GDP & & $-0.020(0.398)$ & & $-0.741(0.223)^{\star \star x}$ \\
\hline
\end{tabular}

Notes Column headings are as follows: (1) output growth, (2) price instability, (3) interest rate, (4) trade balance. ${ }^{* *}$, ${ }^{* *}$, and ${ }^{*}$ denote rejection of null hypothesis at $1 \%, 5 \%$ and $10 \%$ significance levels respectively.

rate, interest rate and trade balance per capita by $0.61 \%, 1.08 \%, 2.0 \%$ and $14.37 \%$ respectively. It suggests that Naira depreciation stimulates economic activity and trade balance but adversely affects the cost of doing business and create price instability. The result is in tandem with the findings of Ogbonna (2011); Umoru and Oseme (2013) and Adediran, Yusuf, and Adeyemi (2014) that currency depreciation improves trade balance and output growth. However, the improvement has its economic costs in terms of high cost of business and inflation. Thus, the study found that naira depreciation enhances economic performance.

The result also found that openness to trade has a significant and adverse effect on trade balance and the overall output growth of the Nigerian economy. A 10\% increase in trade openness deteriorates per capita output and trade balance by $1.01 \%$ and $3.81 \%$ respectively. Likewise, openness to trade has a positive and significant impact on inflation rate and interest rate. It implies that inflation rate and interest rate increase by $0.8 \%$ and $7.1 \%$ respectively as a result of $10 \%$ increase in openness of trade. The result further showed the coefficients of investment have a positive impact on interest rate and trade balance while it negatively affects output. A $10 \%$ increase in investment leads to a decrease in output by $0.54 \%$. Also, an increase in investment by $10 \%$ leads to an increase in interest rate and trade balance by $9.3 \%$ and $2.33 \%$ respectively. The result also indicates that the coefficient of money supply has no significant impact on inflation rate and interest rate. Conversely, the coefficient of income per capita has a negative but insignificant impact on the inflation rate. 
TABLE 6 ARDL Short-run Coefficients: Model 1

\begin{tabular}{lrrrr}
\hline Variables & Coefficient & Std. error & $t$-statistics & Probability \\
\hline$\Delta(\operatorname{GDP}(-1))$ & 0.103691 & 0.171844 & 0.603400 & 0.5527 \\
$\Delta(\operatorname{GDP}(-2))$ & -0.138708 & 0.171330 & -0.809598 & 0.4272 \\
$\Delta(\mathrm{GDP}(-3))$ & 0.285443 & 0.164249 & 1.737872 & 0.0969 \\
$\Delta(\mathrm{HC})$ & 0.238296 & 0.176991 & 1.346376 & 0.1925 \\
$\Delta(\mathrm{EX})$ & -0.086272 & 0.040394 & -2.135766 & 0.0446 \\
$\Delta(\operatorname{EX}(-1))$ & -0.030093 & 0.049479 & -0.608186 & 0.5496 \\
$\Delta(\operatorname{EX}(-2))$ & -0.048727 & 0.040808 & -1.194074 & 0.2458 \\
$\Delta(\operatorname{TO})$ & -0.065438 & 0.056581 & -1.156537 & 0.2604 \\
$\Delta(\operatorname{TO}(-1))$ & 0.041455 & 0.062322 & 0.665169 & 0.5132 \\
$\Delta(\operatorname{TO}(-2))$ & -0.093743 & 0.064255 & -1.458911 & 0.1594 \\
$\Delta(\operatorname{TO}(-3))$ & 0.137556 & 0.063402 & 2.169584 & 0.0417 \\
$\Delta(\operatorname{INV})$ & -0.053294 & 0.082225 & -0.648154 & 0.5239 \\
$\Delta(\operatorname{INV}(-1))$ & 0.183514 & 0.087796 & 2.090242 & 0.0489 \\
$\Delta(\operatorname{INV} 2))$ & -0.188776 & 0.088033 & -2.144369 & 0.0439 \\
$\Delta(\operatorname{INV}(-3))$ & 0.203321 & 0.066493 & 3.057752 & 0.0060 \\
$\operatorname{ECT}(-1)$ & -0.216512 & 0.100963 & -2.144469 & 0.0432 \\
\hline
\end{tabular}

The dynamic short-run estimates report both positive and negative relationship between the lags of Naira depreciation and macroeconomic performance, as presented in tables 6-9. The coefficients of the error correction term (ЕСТ) for the models were found to be negative and significant at $5 \%$ significance level ranging within the magnitude of $11.2 \%$ and $48.5 \%$. It implies that approximately, $11.2 \%$ to $48.5 \%$ disequilibrium in the previous year's shocks on macroeconomic performance converge to longrun equilibrium in the current year. Thus, this supports the existence of long-run relationship between exchange rate and macroeconomic performance in Nigeria.

The diagnostic and stability tests are presented in table 10. The estimated models passed all diagnostic tests indicating that the error terms have same variance, are normally distributed and uncorrelated. The functional form test confirms that the models are well specified except output growth and interest rate models that failed the serial correlation and functional form tests respectively. The results of cumulative sum and cumulative sum of square fall within the critical bounds at $5 \%$ significance level indicating that the parameters are stable over the sample periods. 
TABLE 7 ARDL Short-run Coefficients: Model 2

\begin{tabular}{lrrrr}
\hline Variables & Coefficient & Std. error & t-statistics & Probability \\
\hline$\Delta(\mathrm{CPI}(-1))$ & 0.691703 & 0.134822 & 5.130471 & 0.0001 \\
$\Delta(\mathrm{CPI}(-2))$ & -0.334044 & 0.155172 & -2.152728 & 0.0444 \\
$\Delta(\mathrm{CPI}(-3))$ & 0.296855 & 0.152035 & 1.952538 & 0.0658 \\
$\Delta(\mathrm{EX})$ & 0.015639 & 0.052347 & 0.298749 & 0.7684 \\
$\Delta(\mathrm{EX}(-1))$ & -0.131723 & 0.060822 & -2.165715 & 0.0433 \\
$\Delta(\mathrm{EX}(-2))$ & 0.120070 & 0.066886 & 1.795148 & 0.0886 \\
$\Delta(\mathrm{EX}(-3))$ & -0.144823 & 0.055389 & -2.614639 & 0.0170 \\
$\Delta(\mathrm{TO})$ & -0.022886 & 0.060006 & -0.381400 & 0.7071 \\
$\Delta(\mathrm{TO}(-1))$ & 0.061598 & 0.070359 & 0.875482 & 0.3922 \\
$\Delta(\mathrm{TO}(-2))$ & -0.121883 & 0.068936 & -1.768052 & 0.0931 \\
$\Delta(\mathrm{MS})$ & -0.127220 & 0.075814 & -1.678055 & 0.1097 \\
$\Delta(\mathrm{MS}(-1))$ & 0.165312 & 0.088561 & 1.866651 & 0.0775 \\
$\Delta(\mathrm{MS}(-2))$ & -0.006453 & 0.085367 & -0.075590 & 0.9405 \\
$\Delta(\mathrm{MS}(-3))$ & -0.110480 & 0.067213 & -1.643730 & 0.1167 \\
$\Delta(\mathrm{GDP})$ & -0.758488 & 0.215093 & -3.526319 & 0.0023 \\
$\Delta(\mathrm{GDP}(-1))$ & 0.527733 & 0.264206 & 1.997429 & 0.0603 \\
$\Delta(\mathrm{GDP}(-2))$ & -0.885079 & 0.225297 & -3.928498 & 0.0009 \\
$\mathrm{ECT}(-1)$ & -0.252040 & 0.044018 & -5.725830 & 0.0000 \\
\hline
\end{tabular}

\section{Conclusion}

The Nigerian economy depends so much on the proceeds of crude oil exports, which is foreign currency denominated. Hence, it has serious implications on the Nigerian economy pertaining to budget preparation. It also makes the economy susceptible to external shocks. The recent fall in the international crude oil price plunged the country into recession and put pressure on its external reserve. This prompted a study of this nature between 1970 and 2015. The study adopted the ARDL bound testing approach to establish the macroeconomic implications of exchange rate depreciation on income, inflation rate, interest rate and trade balance. It was confirmed that naira depreciation has a positive and significant impact on all the indicators of macroeconomic performance except for output per capita, which was found to be insignificant. This suggests that Naira depreciation stimulates economic activity and trade balance but also cause price instability and high-interest rate. 
TABLE 8 ARDL Short-Run Coefficients: Model 3

\begin{tabular}{lrrrr}
\hline Variables & Coefficient & Std. error & $t$-statistics & Probability \\
\hline$\Delta(\mathrm{EX})$ & 0.449025 & 0.109941 & 4.084253 & 0.0004 \\
$\Delta(\mathrm{EX}(-1))$ & 0.072957 & 0.147115 & 0.495923 & 0.6241 \\
$\Delta(\mathrm{EX}(-2))$ & -0.272227 & 0.155551 & -1.750076 & 0.0919 \\
$\Delta(\mathrm{EX}(-3))$ & 0.321780 & 0.113559 & 2.833594 & 0.0088 \\
$\Delta(\mathrm{TO})$ & 0.342377 & 0.129655 & 2.640682 & 0.0138 \\
$\Delta(\mathrm{INV})$ & -0.353070 & 0.176507 & -2.000321 & 0.0560 \\
$\Delta(\operatorname{INV}(-1))$ & 0.009363 & 0.253250 & 0.036972 & 0.9708 \\
$\Delta(\operatorname{INV}(-2))$ & -0.050365 & 0.248222 & -0.202902 & 0.8408 \\
$\Delta(\operatorname{INV}(-3))$ & -0.303311 & 0.191648 & -1.582647 & 0.1256 \\
$\Delta(\operatorname{MS})$ & 0.137267 & 0.177800 & 0.772032 & 0.4471 \\
$\Delta(\operatorname{MS}(-1))$ & -0.431731 & 0.160977 & -2.681945 & 0.0125 \\
$\operatorname{ECT}(-1)$ & -0.484618 & 0.111190 & -4.358479 & 0.0002 \\
\hline
\end{tabular}

TABLE 9 ARDL Short-Run Coefficients: Model 4

\begin{tabular}{lrrrr}
\hline Variables & Coefficient & Std. error & $t$-statistics & Probability \\
\hline$\Delta(\mathrm{TB}(-1))$ & 0.290198 & 0.142747 & 2.032955 & 0.0497 \\
$\Delta(\mathrm{EX})$ & 0.160992 & 0.043268 & 3.720828 & 0.0007 \\
$\Delta(\mathrm{TO})$ & 0.598303 & 1.736739 & 0.344498 & 0.7325 \\
$\Delta(\mathrm{INV})$ & 0.260575 & 0.172362 & 1.511791 & 0.1396 \\
$\Delta(\mathrm{GDP})$ & 1.175869 & 0.619252 & 1.898855 & 0.0659 \\
$\mathrm{ECT}(-1)$ & -0.112026 & 0.019275 & -5.812040 & 0.0000 \\
\hline
\end{tabular}

The study is in line with Junz and Rhomberg (1973), Wilson and Takacs (1979), and Bahmani-Oskooee and Kara (2003), which suggested that currency depreciation enhances trade balance of countries operating fixed exchange rate. It is also in tune with Ali and Anwar (2011), which found that exchange rate fluctuation results in a price increase and an improvement in the trade balance. The study confirms the existence of a long-run relationship between exchange rate depreciation and macroeconomic performance in Nigeria. We therefore conclude that exchange rate depreciation has severe implications on macroeconomic performance in Nigeria. To this end, it is pertinent to diversify trade by embarking on export promotion strategies that can sustain gains of exchange rate movements and mitigate its negative consequences on the economy. 
TABLE 10 Model Diagnostic and Stability Tests

\begin{tabular}{|c|c|c|c|c|}
\hline \multirow[t]{2}{*}{ Test statistics } & \multicolumn{4}{|c|}{ Dependent variables } \\
\hline & (1) & (2) & (3) & (4) \\
\hline Serial correlation & $5.1299(0.017)$ & $5.789(0.009)$ & $4.214(0.270)$ & $1.841(0.175)$ \\
\hline Funct. form & $1.2351(0.231)$ & $2.063(0.054)$ & $0.948(0.352)$ & $0.814(0.433)$ \\
\hline Normality & $1.420(0.492)$ & $1.100(0.577)$ & $1.199(0.349)$ & $0.499(0.779)$ \\
\hline Heteroskerdasticity & у $0.503(0.935)$ & $1.328(0.317)$ & $0.473(0.934)$ & $1.373(0.289)$ \\
\hline CUSUM & Stable & Stable & Stable & Stable \\
\hline CUSUMQ & Stable & Stable & Stable & Stable \\
\hline $\operatorname{ECT}(-1)$ & \multicolumn{4}{|c|}{$-0.217(0.101)^{\star * *}-0.252(0.044)^{* * *}-0.485(0.111)^{* * *}-0.112(0.019)^{* * *}$} \\
\hline
\end{tabular}

\section{References}

Abeysinghe, T., and T. L. Yeok. (1998). 'Exchange Rate Appreciation and Export Competitiveness: The Case of Singapore.' Applied Economics 30:51-5.

Adediran, J. O., S. A. Yusuf, and O. A. Adeyemi. (2014). 'The Impact of Exchange Rate Fluctuation on the Nigerian Economic Growth: An Empirical Investigation.' International Journal of Academic Research in Business and Social Sciences 4 (8): 224-33.

Adrangi, B., K. Raffiee, and T. M. Shank. (2007). 'An Ex-Post Investigation of Interest Rate Parity in Asian Emerging Markets.' International Business and Economics Research Journal 6 (2): 29-48.

Ali, S. Z., and S. Anwar. (2010). 'Exogenous Shocks and Exchange Rate Management in Developing Countries: A Theoretical Analysis.' International Journal of Business and Globalisation 4 (4): 338-58.

- (2011). 'Supply-Side Effects of Exchange Rates, Exchange Rate Expectations and Induced Currency Depreciation.' Economic Modelling 28:1650-72.

Athukorala, P. (1991). 'Exchange Rate Pass-Through: The Case of Korean Exports of Manufactures.' Economic Letters 35:79-84.

Athukorala, P., and J. Menon. (1994). 'Pricing to Market Behaviour and Exchange Rate Pass-Though in Japanese Exports.' The Economic Journal 104:271-81.

Bahmani-Oskooee, M., and O. Kara. (2003). 'Relative Responsiveness of Trade Flows to a Change in Prices and Exchange Rate.' International Review of Applied Economics 17:293-308. 
Ball, L. (1999). 'Efficient Rules for Monetary Policy'. International Finance 2:63-83.

Beckington, J. S., and M. R. Amon (2011). 'Competitive Currency Depreciation: The Need for a More Effective International Legal Regime.' Journal of International Business and Law 10 (2): 208-68.

Chang, M., and C. Su. (2015). 'Does Real Interest Rate Parity Really Hold? New Evidence from G7 Countries.' Economic Modelling 47:299-306.

Cherop, C. K., and J. R. Changwony. (2014). 'A Survey of Exchange Rate Fluctuation on Tea Export Earnings among Smallholder Tea Factories in Kenya.' Research Journal of Finance and Accounting 5 (8): 1-22.

Cheung, Y., and R. Sengupta. (2013). 'The Impact of Exchange Rate Movements on Exports: An Analysis of Indian Non-Financial Sector Firms.' Journal of International Money and Finance 39:231-45.

Datta, K. (2014). 'Relationship between Currency Depreciation and Trade Balance in India: An Econometric Study.' Journal of Finance and Economics 2 (3): 83-9.

Devarajan, S., J. D. Lewis, and S. Robinson. (1993). 'External Shocks, Purchasing Power Parity, and the Equilibrium Exchange Rate.' The World Bank Economic Review 7:45-63.

Dickey, D. A., and W. A. Fuller. 1979. 'Distribution of the Estimators for Autoregressive Time Series with a Unit Root.' Journal of the American Statistical Association 74(366a): 427-431.

Divakaran, D. N., and S. Gireeshkumar. 2014. 'Currency Depreciation: Causes and its Impact on Indian Economy'. International Journal of Commerce, Business and Management 3 (1): 2319-28.

Dornbusch, R. 1988. 'Real Exchange Rates and Macroeconomics: A Selective Survey' Working Paper 2775, National Bureau of Economic Research, Cambridge, MA.

Edison, H. J. 1987. 'Purchasing Power Parity in the Long Run: A Test of the Dollar/Pound Exchange Rate (1890-1978).' Journal of Money, Credit and Banking 19 (3), 376-387.

Fang, W., Y. Lai, and S. M. Miller. (2005). 'Export Promotion through Exchange Rate Policy: Exchange Rate Depreciation or Stabilization?' Working paper, University of Connecticut, Storrs, CT.

Fidelis, A. (2014). 'People's Perception of the Impact of Currency Devaluation on the Performance of Poverty Alleviation Programmes in Nigeria.' Developing Countries Study 4 (10): 7-16.

Frankel, J. A., and S. J. Wei. 1998. 'Regionalization of World Trade and Currencies: Economics and Politics.' In The Regionalization of the World Economy, edited by J. A. Frankel, 189-226. Chicago: University of Chicago Press.

Froyen, R. T., and A. V. Guender. (200o). 'Alternative Monetary Policy 
Rules for Small Open Economies.' Review of International Economics 8:721-40.

Guitian, M. (1976). 'The Effects of Changes in the Exchange Rate on Output, Prices, and the Balance of Payments.' Journal of International Economics 6:65-74.

He, H., O. Ranjbar, and T. Chang. (2013). 'Purchasing Power Parity in Transition Countries: Old Wine with New Bottle.' Japan and the World Economy 28:24-32.

Hooy, C., S. Law, and T. Chan. (2015). 'The Impact of the Renminbi Real Exchange Rate on ASEAN Disaggregated Exports to China.' Economic Modelling 47:253-9.

Ike, D. N. (1984). 'Some Economic Considerations for Nigerian Currency Devaluation.' The Indian Journal of Economics 65(1): 69-73.

Junz, H., and R. R. Rhomberg. (1973). 'Price Competitiveness in Export Trade among Industrial Countries.' American Economic Review, Papers and Proceedings 63:412-8.

Kandil, M. (2004). 'Exchange Rate Fluctuations and Economic Activity in Developing Countries: Theory and Evidence.' Journal of Economic Development 29 (1): 85-108.

Kerr, W., and R. King. (1996). 'Limits on Interest Rate Rules in the IS-LM Model.' Federal Reserve Bank of Richmond Economic Quarterly 82:4775.

Kollmann, R. (2005). 'Macroeconomic Effects of Nominal Exchange Rate Regimes: New Insights into the Role of Price Dynamics.' Journal of International Money and Finance 24:275-92.

Li, H., H. Ma, and Y. Xu. (2015). 'How Do Exchange Rate Movements Affect Chinese Exports? A Firm-Level Investigation.' Journal of International Economics 97 (1): 148-61.

Lo, M. C., and J. Morley. (2015). 'Bayesian Analysis of Nonlinear Exchange Rate Dynamics and the Purchasing Power Parity Persistence Puzzle.' Journal of International Money and Finance 51:285-302.

Loto, M. A. (2011). 'Does Devaluation Improve the Trade Balance of Nigeria? A Test of the Marshall-Lerner Condition.' Journal of Economics and International Finance 3 (11): 624-33.

Mamun, A., A. H. Chowdhury, and S. Basher. (2013). 'Effects of Exchange Rate Variation on Price Level and Output Growth in Bangladesh.' Mediterranean Journal of Social Sciences 4 (6): 205-12.

Matsuyama, K., N. Kiyotaki, and A. Matsui. (1993). 'Toward a Theory of International Currency.' The Review of Economic Studies 60:283-307.

McCallum, B. T., and E. Nelson. (1999). 'An Optimizing Is-L M Specification for Monetary Policy and Business Cycle Analysis.' Journal of Money, Credit and Banking 31:296-316. 
Mengistu, A. A., and J. Lee. (2013). 'Examining the Effects of Currency Depreciation on Trade Balance in Selected Asian Economies.' International Journal of Global Business 7 (1): 59-76.

Mishkin, F. S. (1996). 'The Channels of Monetary Transmission: Lessons for Monetary'. NBER Working Paper 5454, National Bureau of Economic Research, Cambridge, MA.

Nouira, R., P. Plane, and K. Sekkat. (2011). 'Exchange Rate Undervaluation and Manufactured Exports: A Deliberate Strategy?' Journal of Comparative Economics 39 (4): 584-601.

Nyeadi, J. D., O. Atiga, and C. A. Atogenzoya. (2014). 'The Impact of Exchange Rate Movement on Export: Empirical Evidence from Ghana.' International Journal of Academic Research in Accounting, Finance and Management Sciences 4 (3): 41-48.

Ogbonna, B. C. (2011). 'The Impact of Exchange Rate Variations on Trade Balance: Evidence from Nigeria.' Journal of Research in National Development 9 (2): 393-403.

Ogundipe, A. A., and S. Egbetokun. 2013. 'Exchange Rate Pass-through to Consumer Prices in Nigeria.' European Scientific Journal 9 (25): 110-123.

Paudel, R. C., and P. J. Burke. (2015). 'Exchange Rate Policy and Export Performance in a Landlocked Developing Country: The Case of Nepal.' Journal of Asian Economics 38:55-63.

Pesaran, M. H., Y. Shin, and J. S. Richard. (2001). 'Bounds Testing Approaches to the Analysis of Level Relationships.' Journal of Applied Econometrics 16 (3): 289-326.

Taylor, J. B. (1993). Macroeconomic Policy in a World Economy: From Econometric Design to a Practical Operation. New York: Norton.

- (1995). 'The Monetary Transmission Mechanism: An Empirical Framework.' Journal of Economic Perspectives 9:11-26.

Umoru, D., and A. S. Oseme. (2013). 'Trade Flows and Exchange Rate Shocks in Nigeria: An Empirical Result.' Asian Economic and Financial Review 3 (7): 948-77.

Wilson, J. F., and W. E. Takacs. (1979). 'Differential Responses to Price and Exchange Rate Influences in the Foreign Trade of Selected Industrial Countries.' Review of Economics and Statistics 61:267-79.

Wilson, P., and K. C. Tat. (2001). 'Exchange Rates and the Trade Balance: The Case of Singapore (1970 to 1996).' Journal of Asian Economics 12:47-63.

This paper is published under the terms of the Attribution-

NonCommercial-NoDerivatives 4.o International (CC B Y-NC-ND 4.0)

License (http://creativecommons.org/licenses/by-nc-nd/4.o/). 


\title{
Different Ways of Environmental Issue \\ Management by Active Citizens: \\ Case Studies from Hungary
}

\author{
Adrienn Reisinger \\ Széchenyi István University, Hungary \\ radrienn@sze.hu \\ Katalin Bándy \\ Széchenyi István University, Hungary \\ bandy@sze.hu
}

The paper illustrates how active citizens can manage environmental issues by participation in local or national programs or events. The aim of this paper is to provide - on the one hand - the theory of social participation of active citizens with the focus on environmental issues. On the other hand, the paper attempts to illustrate the topic with three good examples from Hungary based on secondary information and interviews. The first one is a program of school gardens; the second one is an issue in Szentgotthárd and is related to the case of a planned incinerator, which was banned by the debut of local civic organisations some years ago. The third program namely TeSzedd (the program is about collecting litter in an organised campaign in Hungary) is a case, which is initiated by a top down approach but managed by local citizens. The results show that citizens can be active in shaping environmental issues but the most important factor seems to be that they need to be concerned personally about the issues.

Key Words: active citizens, social participation, environmental issues, management, good examples

JEL Classification: R11, L 31

https://doi.org/10.26493/1854-6935.16.259-277

\section{Introduction}

Environmental issues can be managed by different kind of actors and different kind of ways. This study illustrates how the active citizens can participate in managing these kinds of issues. Recently, researchers have shown an increased interest in social participation in environmental issues. The aim of this study is to examine good cases in Hungary related to environmental issues management and to add to the literature by providing a list about the different kind of activities in environmental issues. 
These three cases are involved in the research: the method of school gardens, a case in Szentgotthárd and the TeSzedd Program (the program is about collecting litter in an organized campaign in Hungary).

The first part of the study provides a literature overview about active democracy, active citizenship and environmental issues. This part lays out the dimensions of environmental participation and the activity list related to participation. The article continues by introducing three good cases in Hungary. The last part presents the conclusions.

The paper provides guidance also for practitioners and researchers and it also adds some possible good examples about managing environmental issues to the literature. It is possible to believe that learning how to manage these types of activities is our common responsibility.

\section{Theoretical Background: Active Democracy, Active Citizenship and Environmental Issues}

Active democracy (Reisinger 2009) means that citizens take part in those local, regional, national, or just like international issues, which can influence their life and wellbeing. In this democracy, citizens are open for shaping their environment, telling their ideas and solving problems together with other citizens or institutions. Participation of citizens and civil organisations can be termed social participation which is related to social responsibility; people who care about their society in a given way are responsible not just for their own life but also for their society (NáraiReisinger 2016). Newman and Tonkens (2011) have also investigated the relationship between participation and responsibility.

Active democracy and social participation need active citizens. The question arises: who the active citizens are. 'Citizenship defines rights and responsibilities, in turn creating a dynamic debate about the duties of citizens as members of the community. Traditionally, active citizenship has included participating in elections or referendums, standing for a political office, and actively or passively engaging as member of a political party or politically affiliated organisation. However, this strict definition has expanded. A core element of active citizenship is now seen as engagement in civil society through membership in or support of organisations, involvement in political debates and public consultation processes, participation in demonstrations or protests, volunteering, and awareness of topical issues.' (European Youth Forum 2013, 3) As it can be seen, participation is the core concept in this term. Also Hoskins $(2006,10)$ demonstrates active citizenship as 'participation in civil society, community and/or po- 
litical life, characterised by mutual respect and non-violence and in accordance with human rights and democracy.'

Based on these approaches, it is important that active citizenship is more than just voting and knowing the rights, it means that active citizens take certain actions in favour of the society. In the literature, there is no unified concept about the potential activities of an active citizen; the approaches vary from author to author. In one of her previous studies, Reisinger (2017) identified 33 activities along the following fields (Jochum, Pratten, and Wilding 2005; Bee 2017):

- activities related to civil/non-profit organisations or good cases,

- activities concerned with local governments,

- activities from home,

- personal responsibility,

- monitoring and/or intervention in local/national issues, and

- political participation.

Each of the above activity groups include such activities, which are in some from related to environmental issues. Of course it does matter how far-reaching these issues are, who their participants are, and how much time is provided to get information about the given environmental issue, dispute, learn, evaluate the situation and to make a decision if it is needed. It also does matter whether it is a political/governmental issue or an activity that does not require decision-makers participation, that is to say the activity is the local initiation of the citizens. The question may arise why the participation of citizens, civil organisations is necessary at all in these issues. Gabriella Kiss $(2013,30)$ drew up its advantage that 'the more value we involve in the process, the more the knowledge will be and the more the acceptance and trust will increase, and the more we learn democracy and are able to handle the risks together or to agree in avoiding them.' Moreover, activity also means that type of behaviour when citizens behave by protecting their environment, e.g. collecting waste selectively, not lavishing resources, as well as when they appear as supporters in case of environmental issues. In case of these we do not speak about participation in decision-making but about issues affecting our environment in our everyday life. Figure 1, which was created by the authors based on information from the literature and the practice, illustrates the dimensions of participation in environmental issues.

Environmental conscious approach and environmental responsibility are needed to appear in rearing at an early age so that a society could have 


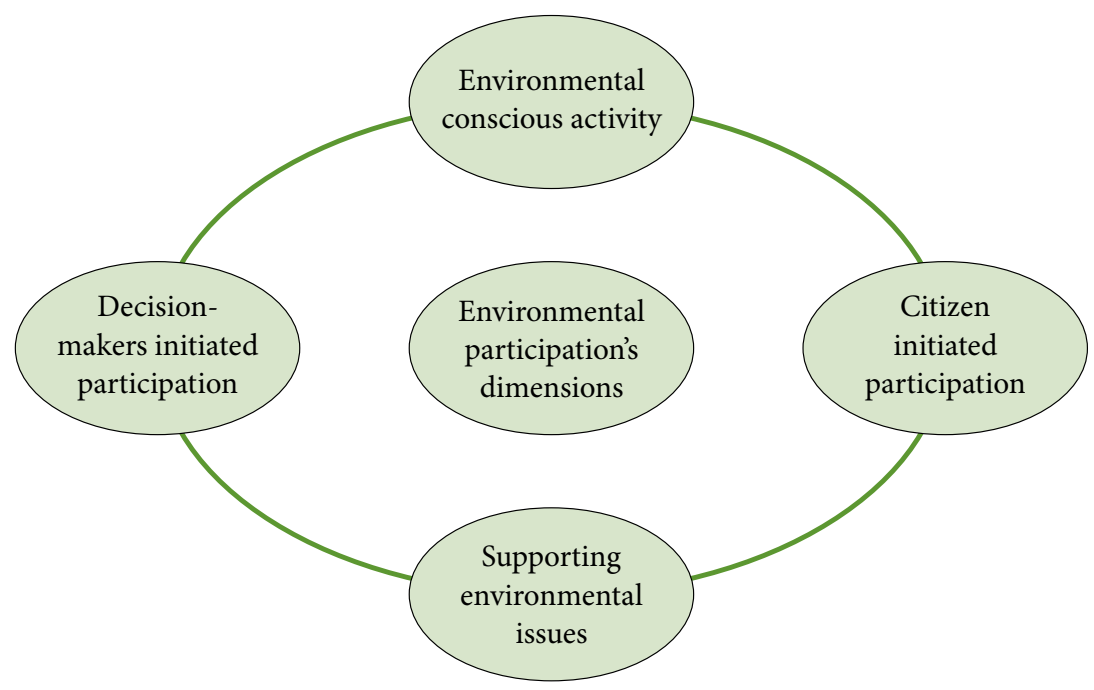

FIGURE 1 Dimensions of Environmental Issue Participation

the highest possible number of active citizens in case of environmental issues. Environmental conscious behaviour means that people habitually pay attention to protect their environment (Major 2012). A citizen will participate in social issues if they feel responsibility towards social actors and processes, which is also true for the participation in environmental issues. Besides responsibility, commitment and the will to act are also needed, thus those citizens who besides realising where they can reach changes with their participation, support, and ideas, also invest time and energy so that their activity could be seen in practice will participate actively in managing and supporting environmental issues. We think that formal education and familial patterns have determining role in this process. In case of education Yueh (2007 cited by Khademi-Vidra 2017, 68) enhances that 'countries in Europe determined that environmental problems are specific to each country and each region and so countries should produce their own Environmental Education programs to solve their own problems.'

There are many ways of being active in environmental issues (table 1). This form of the categorisation of activities cannot be found in the literature, thus table 1 is the own concept of the authors and it collects and categorises the activities of environmental issue management. On the one hand citizens can be active in indirect way, which means that they do not take part directly in activities, but they support them, or they are in- 
TAB LE 1 Types of Environmental Issue Management Activities

\begin{tabular}{|c|c|c|c|c|}
\hline \multirow[t]{2}{*}{ Dimensions } & \multirow[t]{2}{*}{ Indirect way } & \multicolumn{3}{|c|}{ Direct way } \\
\hline & & (1) & (2) & (3) \\
\hline $\begin{array}{l}\text { Environ- } \\
\text { mental } \\
\text { conscious } \\
\text { activity }\end{array}$ & $\begin{array}{l}\text { Getting infor- } \\
\text { mation about } \\
\text { environmental } \\
\text { issues. }\end{array}$ & $\begin{array}{l}\text { Collecting } \\
\text { litter; Selective } \\
\text { waste collection; } \\
\text { Purchasing } \\
\text { environmentally- } \\
\text { friendly items; } \\
\text { Energy-saving } \\
\text { practices. }\end{array}$ & & \\
\hline $\begin{array}{l}\text { Supporting } \\
\text { environ- } \\
\text { mental } \\
\text { issues }\end{array}$ & $\begin{array}{l}\text { Donating to } \\
\text { civil/non-profit } \\
\text { organisations } \\
\text { dealing with } \\
\text { environmental } \\
\text { issues; } 1 \% \text { do- } \\
\text { nation; Writing } \\
\text { blogs on en- } \\
\text { vironmental } \\
\text { topics; Writing } \\
\text { letters to local } \\
\text { representatives } \\
\text { about environ- } \\
\text { mental issues. }\end{array}$ & $\begin{array}{l}\text { Signing up peti- } \\
\text { tion. }\end{array}$ & $\begin{array}{l}\text { Volunteer activ- } \\
\text { ity in civil/non- } \\
\text { profit organi- } \\
\text { sations dealing } \\
\text { with environ- } \\
\text { mental issues; } \\
\text { Being a member } \\
\text { in civil/non- } \\
\text { profit organi- } \\
\text { sations dealing } \\
\text { with environ- } \\
\text { mental issues; } \\
\text { Being a leader in } \\
\text { civil/non-profit } \\
\text { organisations } \\
\text { dealing with } \\
\text { environmental } \\
\text { issues; Working } \\
\text { for civil/non- } \\
\text { profit organi- } \\
\text { sations dealing } \\
\text { with environ- } \\
\text { mental issues. }\end{array}$ & $\begin{array}{l}\text { Signing up peti- } \\
\text { tion. }\end{array}$ \\
\hline
\end{tabular}

Continued on the next page

formed. Perhaps it can be thought that these activities are not real participation but we think that they are. E.g. donating to civil/non-profit organisations dealing with environmental issues is a very important activity, because these organisations have an important role in environmental protection and environmental issue management. On the other hand citizens can be active directly, too, through many kinds of activities. Table 1 illustrates the activities based on the four dimensions shown in figure 1. 
TAB LE 1 Continued from the previous page

\begin{tabular}{|c|c|c|c|}
\hline \multirow[t]{2}{*}{ Dimensions Indirect way } & \multicolumn{3}{|c|}{ Direct way } \\
\hline & (1) & (2) & (3) \\
\hline $\begin{array}{l}\text { Citizen } \\
\text { initiated } \\
\text { participa- } \\
\text { tion }\end{array}$ & $\begin{array}{l}\text { Organising pe- } \\
\text { tition; Signing } \\
\text { up petition; Col- } \\
\text { lecting litter; } \\
\text { Protesting; Inter- } \\
\text { est conciliation. }\end{array}$ & $\begin{array}{l}\text { Organising peti- } \\
\text { tion; Collecting } \\
\text { litter; Protesting; } \\
\text { Interest concilia- } \\
\text { tion. }\end{array}$ & $\begin{array}{l}\text { Organising peti- } \\
\text { tion; Protesting; } \\
\text { Interest concilia- } \\
\text { tion. }\end{array}$ \\
\hline $\begin{array}{l}\text { Decision- } \\
\text { makers } \\
\text { initiated } \\
\text { participa- } \\
\text { tion }\end{array}$ & $\begin{array}{l}\text { Participating in } \\
\text { public hearings } \\
\text { or local forums; } \\
\text { Giving own } \\
\text { ideas in public } \\
\text { hearings or local } \\
\text { forums; Partic- } \\
\text { ipating in Citi- } \\
\text { zens' Juries and } \\
\text { in other forms } \\
\text { of consultative } \\
\text { methods; Giving } \\
\text { own ideas in Cit- } \\
\text { izens' Juries and } \\
\text { in other forms } \\
\text { of consultative } \\
\text { methods; Giving } \\
\text { opinions and } \\
\text { ideas to environ- } \\
\text { mental strategies } \\
\text { and plans; Sign- } \\
\text { ing up petition. }\end{array}$ & $\begin{array}{l}\text { Giving opin- } \\
\text { ions and ideas to } \\
\text { environmental } \\
\text { strategies and } \\
\text { plans; Protest- } \\
\text { ing; Protesting } \\
\text { through legal } \\
\text { way; Interest } \\
\text { conciliation; } \\
\text { Signing up peti- } \\
\text { tion. }\end{array}$ & $\begin{array}{l}\text { Giving opinions } \\
\text { to environmental } \\
\text { strategies and } \\
\text { plans; Protest- } \\
\text { ing; Protesting } \\
\text { through legal } \\
\text { way; Interest } \\
\text { conciliation; } \\
\text { Signing up peti- } \\
\text { tion. }\end{array}$ \\
\hline
\end{tabular}

NOtEs Column headings are as follows: (1) personally, (2) through civil/non-profit organisations, (3) through organised movements.

\section{Case Studies from Hungary}

In this part, we illustrate good practices, which represent the literature background appropriately, and provide a good basis to synthesise it and think it further.

\section{METHODS}

The aim of this study is to illustrate three Hungarian cases about the environment issue management. This qualitative method offers an effective and reliable way to illustrate environmental issue management. Different 
authors have introduced management techniques also with case studies (Kiss 2013; Kasymova and Gaynor 2014; Motherway 2003; Barclay 2016). The following three cases are involved to be examined:

- Local level: school gardens

- Regional level: the case of Szentgotthárd

- National level: TeSzedd Program (the program is about collecting litter in an organised campaign in Hungary)

Of course, there are other good examples in Hungary, however, our aim was to illustrate cases, which have many years of history, are successful, and show in a complex way how variably the citizens can contribute to environmental issue management. We chose cases, which illustrate well at different territorial levels how citizens can participate in environmental issues and form them. Although school gardens are nationally existing organisations, their operation is managed at local level, so they strengthen local participation. In case of school gardens, the emphasis is not put on solving a problem, but on environmental education, environmental consciousness and participation. The case of Szentgotthárd is a good example of how civil organisations and citizens can cooperate against an investment in favour of the area. The third example is a nationally organised movement, a few days long litter collection the aim of which is to clean the country, build community, and to raise environmental consciousness. We think that the method chosen is properly linked to the topic, since we can effectively illustrate with good practices and examples how diversely the citizens can be active in environmental issues management in practice. Table 2 illustrates into which group of activity introduced in table 1 the good cases chosen by the authors could be categorised.

The cases are based on the following information:

- homepages of the cases,

- documents,

- literatures,

- interviews during 2018 spring:

1. András Albert Halbritter: founding member of the Hungarian Foundation for School gardens,

2. Cecília Szigeti: local coordinator of the TeSzedd in Györ.

GARDEN BASED LEARNING: SCHOOL GARDENS

School gardens are not new organisations, their history dates back to the Middle Ages (Subramaniam 2002). Philosophers like e.g. Rossueau, 
TAB LE 2 The Cases Introduced by the Authors Based on the Groups of Table 1

\begin{tabular}{lllll}
\hline Dimensions & Indirect way & \multicolumn{3}{c}{ Direct way } \\
\cline { 2 - 5 } & & $(1)$ & $(2)$ & $(3)$ \\
\hline $\begin{array}{l}\text { Environmental } \\
\text { conscious } \\
\text { activity }\end{array}$ & $\begin{array}{l}\text { Szentgotthárd } \\
\text { TeSzedd }\end{array}$ & $\begin{array}{l}\text { School gardens } \\
\text { TeSzedd }\end{array}$ & \\
\hline $\begin{array}{l}\text { Supporting } \\
\text { environmental }\end{array}$ & Szentgotthárd & $\begin{array}{l}\text { School gardens } \\
\text { Szentgotthárd }\end{array}$ & Szentgotthárd \\
issues & & & \\
\hline $\begin{array}{l}\text { Citizen initi- } \\
\text { ated participa- } \\
\text { tion }\end{array}$ & School gardens & School gardens & Szentgotthárd \\
\hline $\begin{array}{l}\text { Decision- } \\
\text { makers ini- }\end{array}$ & Szentgotthárd & Szentgotthárd & TeSzedd \\
tiated partici- & & & \\
pation & Szentgotthárd & Szentgotthárd & Szentgotthárd \\
\hline
\end{tabular}

NOtEs Column headings are as follows: (1) personally, (2) through civil/non-profit organisations, (3) through organised movements.

Comenius or Montessori at the beginning of the 2 oth century, all emphasised the role of school gardens and practical education. 'School gardens provide a real world context for learning that is distinguishable from typical hand-on learning activities in the classroom, which tend to be simulation of real world experiences.' (Ratcliffe 2007, 101, cited by Wei 2013, 15) School gardens are places in kindergartens, schools where children can learn how to plant and grow e.g. vegetables, but the method is more than just gardening. The different kinds of activities in the garden develop personality, healthy living, responsibility and many kinds of social skills (e.g. cooperation, communication, creativity, etc.). Plants are only tools for teaching children these kinds of things.

There are many reasons why school gardens can contribute to social well-being and environmental consciousness; here are some of them (Desmond, Grieshop, and Subramaniam 2004, 25):

- Gardens can create opportunities for children to discover fresh food, make healthier food choices and become better nourished.

- Gardens offer dynamic settings in which to integrate every discipline including science and maths, language arts, history and social studies, and art.

- Young people can experience deeper understandings of natural systems and become better stewards of the earth. 
- School garden projects nurture community spirit and provide numerous opportunities to build bridges among students, school staff, families, local businesses, and community based organisations. o Links with school gardens, school food service programmes, and local farms can ensure a fresh nutritious diet for children while teaching about sustainable food systems.

School gardens can contribute to active citizenship because participating in school gardens teaches how to think and take care about ourselves, about our environment and about life. It helps being responsible for the environment, learning how to be conscious about the environment and gives certain methods to manage environmental issues. As Ozer (2007, 861) summarised: 'school gardens are a promising approach in promoting the physical, psychosocial, and intellectual development of school-aged children [...]?

School gardens have gained a real popularity all over the world, the first gardens appeared at the beginning of the 19th century, nowadays there are countries where the number of gardens are of the order of thousands; e.g. in Hungary there are more than 1100 school gardens and their number have been still growing.

To support and coordinate Hungarian gardens the Hungarian Foundation for School Gardens was established in 2015. Founding members are all school garden leaders, so they not just manage the organisation but also participate in the everyday work of a certain garden. The goal of the civil organisation can be read on the homepage of the foundation (www.iskolakertekert.hu): 'We would like to achieve by children's own experience the practical learning of responsible environment use, as an adult the ability to think responsibility on their environment. We would like to support children to obtain basic gardening knowledge after finishing schools as teenagers, by which they could contribute to their food supply, thus reducing the dependence and insecurity feelings.' With the following types of activities the foundation can contribute to the development of the school gardens and thereby can raise consciousness in environmental issues:

- establishing the Hungarian School Garden Network,

- maintaining a homepage to provide information,

- establishing a professional team,

- coordinating the work of gardens,

- organising programmes. 
In Hungary school garden-based education was present in teacher's training more than one and a half centuries ago, and the revival of this movement is related to the Department of Natural Sciences CoursePedagogy at the Apáczai Csere János Faculty of Széchenyi István University in Györ. Students participating in teacher's training get training about what it means to maintain a school garden, to cultivate it and to teach and coordinate those children who participate in the operation of it. The students cultivate the school garden located in the area of the faculty together with the pupils of the university's elementary school. The leader of the school garden is a founding member of the foundation as well, moreover, he is an associate professor of the university too.

\section{THE CASE OF SZENTGOTTHÁRD}

Conflict is inseparable from development. There is no development process which would take place without discrepancies; the definition of advancement, development includes discrepancy [...] If a development action takes place in a given territory, the starting point of the involved active participants is not necessarily the same. Everyone may have their own specific conception about the procedures to be followed, even if development is the common point for all of them. [Caul-Futy 1997, 7]

One of the success stories of active citizenship movement at regional level was an environmentally damaging investment that had been impeded by the joint action of a Hungarian city and its inhabitants and the joined civil organisations (the introduction of the investment is based on the study of Bándy (2010), and is a further-thought, revised, and completed version of it).

The only cross-border industrial park of Hungary (and Europe) is the Szentgotthárd-Heiligenkreuz Industrial Park, which was established in 1997. In 2006 Begas Kraftwerk GmbH planned to build in this industrial park, a thermal waste recycling plant which is apt for incinerating 200000 tons of waste annually. According to the company's investment promise including 115 million euro, the plant may be apt for the economic and long-term supply of electricity and heat energy to regional plants. The developed energy would fully supply the whole industrial park, the province of Burgenland (Austria), and a part of Szentgotthárd as well (Lebensministerium 2009).

However, the inhabitants of Szentgotthárd, the leaders of the city, several civil organisations, and some environmental initiations found the 
building of the incinerator troubling. According to their objection, even though the incinerator would be built on the Austrian side, it would be only 100 meters away from the Hungarian border, in the immediate vicinity of Szentgotthárd city having 10 ooo inhabitants, and right next to three national parks. It was troubling that the plant would be built on the easternmost part of Burgenland, the furthest from Austrian cities in a place where the prevailing wind direction is north-eastern. It all meant that environmental burden would mostly affect Hungary, the Örség National Park, the Szentgotthárd Thermal Park (investment value is 6.5 million euro), and the psychiatric institution in the surrounding area, the rehabilitation hospital, and the two elementary school educating one thousand children.

The investor got its own experts to make an impact study (RVH 2009) to prove that the plant would produce clean and cost-effective energy out of harmless waste. Begas emphasised its commitment to environmental protection and its high level of responsibility towards the quality of life in the region. In its environmental impact, study it clearly pointed out that the proper operation of the waste recycling plant did not have a negative impact on either the region or the direct environment. By building the energy park, Begas promised the creation of workplaces, and also adumbrated the possibility to minimize the costs of regional waste transport by building the plant.

The city of Szentgotthárd and its local government as well as the civil organisations learnt about the plan of Begas to build the plant right next to the Hungarian border first from Austrian, then from Hungarian media in the spring of 2006. Although the leadership of the city immediately asked for official information from the province of Burgenland, they did not get anything. After that, the city of Szentgotthárd turned to the Hungarian Ministry of Environment and Water. The Ministry asked for official reference from the Austrian government, but it was rejected by the Austrians by referring to the unavailability of an impact study which could be a basis for an official reference.

It is a highly important milestone that almost right after the news about the planned plant a civil initiation, the Pronas (Pro Natura St. Gotthard Civil Cooperation Association) an association containing more civil organisations was formed. The primary aim of Pronas initiation was to impede the building of the incinerator, and right after its establishment, it showed activity in this case. It attracted the attention with regular presentations, forums and demonstration, and maintained the interest to im- 
pede the investment. Due to government interest, Begas stated in an official announcement that they aimed at incinerating the waste produced in Burgenland. It is, however, contradictory considering the capacity of the planned plant. Burgenland's annual amount of waste, which is apt for incineration, is 15 thousand tons, while the capacity of the plant is 250 thousand tons according to the investor. Technical parameters were examined by an independent engineer expert office (Data Bridge 2007) which, based on the investor's data, stated that the plant might be apt for incinerating even 325 thousand tons of waste annually. Due to these discrepancies, it was assumed that the investor did not only want to destroy the waste of Burgenland, but the plant's capacity provided the possibility to destroy the waste of other provinces and later probably that of the neighbouring countries.

Knowing the rate and amount of dangerous and non-dangerous waste is extremely important. Site selection was troubling from the viewpoint of air protection as well, especially if we consider that fact that the investor wanted to build the plant in an area surrounded by natural reserves. The Austrian impact study did not consider these aspects and did not contain alternative solutions. Based on the expert opinions, the local government of Szentgotthárd stated its attitude, and tried to solve the problem by continuously involving higher forum.

Accessing the status of party was a very important element in the process. The Viennese law firm entrusted by the local government highlighted that providing the status had been legitimate according to the Austrian legislations. The initiation got a wider space by accessing the status of party since some decrees could be impeded by it (the study of Gajdics 2012 describes the role of party status in more details).

Civils reacted to the problem very fast, and then an exemplary environmental struggle began by accessing the status of party. Pronas, as the only civil organisation having a party status, was able to act more effectively against the investment than the initiations of private individuals. They acquired financial sources by tender options for the events and the professional work, and then they fought against the building of the plant for six and a half years. Their activity was characterised by spectacular demonstrations and professionalism, the result of which was that they, as parties in the authorisation process, made themselves all the professional materials. Petitions compiled for Umweltsenat represented both professionally and legally such a based viewpoint, which was apt for making arguments in the course of decision-making. In the meantime, the 'simple' environ- 
mental issue, beyond the legal process, became a political and diplomatic issue as well. Therefore the civils and the local government were backed by the competent ministry of the Hungarian government and the then President of the Republic (László Sólyom). The Ministry of Environment and Water (KVVM 2008) also published its viewpoint according to which the requirement for constant governmental interference is reasonable.

Due to the civil movement's significant activity, they succeeded in gaining over and bringing out all the highest representatives of the country over, and in extending the problem to internationalisation. Because of the desperate work, the media dealt with the incineration on a daily basis.

In this case, the importance of active citizenship highlighted that its tools were much wider than protest. Manifestations may include such effective tools, which mean the category of civil obedience, e.g. human chain, banners, strikes, halfway road closure. In 2007 the activity of Pronas brought Pro Pannonia into being, which was a cooperation against the incineration consisting of three countries (Slovenia, Austria, Hungary); and also in 2007 the Austrian cooperation partner of Pronas, an environmental civil organisation, the Bigas (Bürgerinitiative gegen Abfallschweinerei) was established. It can be said that as a result of the significant civil cooperation, Pronas represented the interests and the wish of the inhabitants against the incineration in the most effective way, because due to its enduring activity the investor withdrew its plan to build the incinerator. The enduring work of six and a half years, 162 events, and the cooperation of 30 thousand people proved the power of active citizenship aspiration as well as its exemplary successfulness (table 3 ).

Conflict is inseparable from development. Based on the case of Szentgotthárd, an important statement can be made: the cooperation of an affected community with the support of civil organisations may reach exemplary results. The plant would have already been built in the Szentgotthárd-Heiligenkreuz Industrial Park if the civil organisations had not cooperated with the city and the citizens following the public protest. In this case the importance and the efficiency of the civil organisation can be measured in that it did not only play the role of a 'communication channel' (Reisinger 2010) during the mediation between the citizens and the investor, but it represented the case as a party during the legal forums.

TESZEDD! PROGRAM

The national level of the volunteer movement is the 'TeSzedd' Volunteering for a clean Hungary program (http://szelektalok.hu/teszedd). The 
TA B LE 3 The Chronological Order of the Most Important Events against the Incineration Plant

\begin{tabular}{|c|c|}
\hline Important dates & Events \\
\hline May 2006 & News from the papers about the investment as a fact \\
\hline June 2006 & Civil protest at the border \\
\hline July 2006 & BEGAS Information Day in a Public Forum \\
\hline November 2006 & Establishment the PRONAS \\
\hline $2006-2008$ & Several conferences, protests, court files, referendum \\
\hline February 2009 & Burgenland Provincial Office gives permission for the plant \\
\hline 2009 & More protests (inc. hunger strike), involving international lawyers \\
\hline June 2010 & Judicial permission in Austria for the investment \\
\hline January 2012 & $\begin{array}{l}\text { In Güssing (Austria) Arnold Schwarzenegger's agitation for en- } \\
\text { vironmental friendly energy. Energy Globe Award for the ex- } \\
\text { governor (USA). }\end{array}$ \\
\hline May/June 2012 & The Administrative Court Vienna cancelled the permission \\
\hline November 2012 & $\begin{array}{l}\text { Declaration in official } \mathrm{TV} \text { channel in Austria (ORF): 'There will be } \\
\text { no waste incinerator' }\end{array}$ \\
\hline $2013-2015$ & Acknowledgements, conferences about the success, awards, prizes \\
\hline
\end{tabular}

acronym 'TeSzedd' in English is 'YouPick Campaign' (official) which means that you pick up the litter yourself from the council land. This is a waste picking day, a national clean-up program organised by the Ministry of Rural Development and National Waste Management Agency. It has been taking place for seven years and organised in every September, and lasts three days long. The movement was first organised in Hungary in 2011 as an action against the illegal dumping of waste.

The aims of the action are as follows:

- to bring together all those who want to do it in order to live in a cleaner, healthier environment,

- to destroy the illegally decomposed garbage dumps,

- to promote an environmentally conscious way of thinking,

- to focus public attention on the importance of preserving a sustainable environment,

- preventing waste generation,

- to raise citizens' awareness on the litter problem,

- help changing people's behaviour. 
TABLE 4 'TeSzedd' in Numbers

\begin{tabular}{llll}
\hline Year & $\begin{array}{l}\text { Number of partici- } \\
\text { pants (registered) }\end{array}$ & Number of venues & Litter (in 1000 tons) \\
\hline 2011 & 162000 & 1500 & No data \\
2012 & 110000 & 1500 & 3 \\
2013 & 75500 & 1074 & 2,5 \\
2014 & 180000 & 1800 & $2-3$ (estimation) \\
2015 & 170000 & 1590 & 2,3 \\
2016 & 190000 & 2240 & 2,8 \\
2017 & 175000 & 1732 & 2,5 \\
\hline
\end{tabular}

NOTES Based on data from http://szelektalok.hu/teszedd/, www.ewwr.eu/en/take _part/lets-clean-up-europe, www.kormany.hu, www.opsz.hu/teszedd-programleiras, www.unesco.hu/termeszettudomany/fenntarthato-fejlodesre/teszedd-orszagos.

In 2014 Hungary joined with its national program to the 'Let's Clean Up Europe' ('European Clean-Up Day') organised in all E U member countries. The head organiser is the European Committee's EW W R LIFE+ program, the European Week for Waste Reduction. Since 2014 Hungary has taken part in these two movements in May and September.

The organisers want to inspire people to get outdoors, get active and help clear up the rubbish that lies around us. The movement is growing year by year by the joining of people who have had enough of other people's litter and are willing to do something about it. The movement is also an excellent opportunity to develop a closer relationship between schools, kindergartens and families, but it is also a perfect team-building program for teams.

Table 4 illustrates the development of the program year by year. In 2014, when Hungary first joined to the 'Let's Clean Up Europe' program, the country alone (among all Eu participant countries) fulfilled the collection of the amount of waste which the EU expected to be collected by all $\mathrm{EU}$ members in a four year period.

Joining to the program is easy: the volunteer can find the territorial coordinator person on the movement's website (http://szelektalok.hu/). After it he needs to register by choosing the nearest point to the volunteer location (find venue and date). Then the volunteer must go to the venue. On the spot, the coordinator and the other organisers provide all the equipment necessary including gloves, bags and best practices for collecting litter. Participants can join to the movement also collectively 
e.g. from firms, public administration organisers and from the army, too.

The value of the work done by the volunteers is around 5 million euro per year. The number of the volunteers could be much more than that of the registered ones, because of the possibility to join randomly on the chosen venue. That is why the estimated number of the participants may be more by $30-40 \%$.

The activity left a great impact on the community since they are already aware of cleaning their areas. Volunteering is a perfect way to participate in our community, meet people, and use the skills we have or learn new ones. It is also a great opportunity to try new challenges and connect with like-minded others.

\section{Conclusion}

The main aim of the paper was to show the literature overview of the environmental issues management and active citizenship and to introduce three Hungarian good cases about the practice. The method we used is broadly in line with the topic. We attempted to find out the dimensions and types of activities of environmental issue management. Our findings add to the growing body of literature on determining the types of activities in a direct and indirect way in four dimensions shown in this paper based on the concept of the authors. The good practices introduced by the authors can also be fitted in these dimensions.

The paper illustrated three cases in Hungary, the first case is a teaching method for young people, the school gardens. This case is not about solving a certain environmental issue, but is a good method to raise a generation who consciously deals with their environment, takes responsibility for their environment and for each other, learns to work together and to be creative, and by these as adults they will be able to become aware of those processes that require their participation. All in all, we stated that school gardens can be one of the main tools for educating active citizenship. In this process the Hungarian Foundation for School Gardens, the civil organisation introduced in this paper, plays an important role.

The case of Szentgotthárd is not only valuable as a success story, but it also illustrates well the issues of sustainability and development. The building of the incinerator could have solved a regional problem if we only examine one side. Because of its capacity, the destruction of huge amount of waste could have been handled successfully in an organised way. The plant promised workplaces, electricity-supply for the region free of charge, which creates very important advantages in economic opera- 
tion and development. The growth of a system's capacity is useful as long as it is sustainable. If the 'by-product' of growth is destruction and demolition, development cannot be a need (Lányi 2012, 11).

The cooperation of local small communities is an important tool for ecological sustainability and environmental protection. Local cooperation induces global results. The domestic 'TeSzedd' program is a wellorganised and successful action, but fortunately is not unparalleled. Local initiations have been growing everywhere all over the world, from Estonia to Egypt, from Kosovo to the United States. Globally millions of people join to waste collection actions, accomplishing a work valuing tens of millions of dollars or euros by country. In the global 'Let's do it!' movement 9 million people could be involved in 110 countries over 6 years (http://szelektalok.hu/globalis-szemetszedes/). It is a significant result, especially if we highlight that all these are based on individual responsible thinking and volunteering.

Results show that citizens can be active in shaping environmental issues but the most important factor seems to be that they need to be concerned personally about the issues. We think that the cases introduced in this paper are good ones as examples of environmental issue management and can contribute to the social participation and to active citizenship. In the future the knowledge about activities can be further extended and deepened by studying and analysing other cases and this knowledge can further develop both the theoretical basis and the possibilities of practical implementation.

\section{Acknowledgments}

Supported by the ÚNK P-17-4 New National Excellence Program of the Ministry of Human Capacities.

\section{References}

Bándy, K. 2010. 'Szentgotthárd kontra Begas-Kraftwerk Gmbh: Konfliktusok egy hulladékégető körül.' In Válság közben, fellendülés elött, edited by M. Losoncz and C. Szigeti. Győr: Széchenyi István Egyetem. https://kgk.sze.hu/images/dokumentumok/kautzkiadvany2010/bandy \%2okatalin.pdf

Barclay, N. 2016. 'The Role of Community Participation for Green Stormwater Infrastructure Development.' PhD Dissertation, Clemson University, Clemson, sc.

Bee, C. 2017. Active Citizenship in Europe. London: Palgrave Macmillan. 
Caul-Futy, L. 1992. 'Fejlesztés és konfliktus.' Parola - folyóirat a közösségi fejlesztőmunkáról 3 (1): 7.

Data Bridge. 2007. 'Levegővédelmi transzmissziós számítások üzemi pontforrásokra az RVH Reststoffverwertungs Gmbh beruházásában a Heiligenkreuz-Szentgotthárd ipari parkban létesítendő termikus hulladékhasznosító mü Környezeti Hatástanulmányának értékeléséhez.' Székesfehérvár, Data Bridge.

Desmond, D., J. Grieshop, and A. Subramaniam. 2004. Revisiting GardenBased Learning in Basic Education. Rome: Food and Agriculture Organization of the United Nations; Paris: International Institute for Educational Planning.

European Youth Forum. 2013. 'Policy Paper on Citizenship Education.' http://www.youthforum.org/policypaper/policy-paper-on-citizenship -education/

Gajdics, Á. 2012. 'Ügyféli jogok érvényesítése.' In Cselekedj lokálisan! Társadalmi részvétel környezeti ügyekben, edited by A. Pánovics and V. Glied, 169-8o. Pécs: Publikon.

Hoskins, B. 2006. A Framework for the Creation of Indicators on Active Citizenship and Education and Training for Active Citizenship. Ispra: Joint Research Centre.

Jochum, V., B. Pratten, and K. Wilding. 2005. Civil Renewal and Active Citizenship: A Guide to the Debate. London: NCvo.

Kasymova, J., and T. S. Gaynor. 2014. 'Effective Citizen Participation in Environmental Issues: What Can Local Governments Learn?' State and Local Government Review 46 (2): 138-45.

Khademi-Vidra, A. 2017. 'Curriculum Planning of the Environmental Education.' Journal of Central European Green Innovation 5 (1): 65-80.

Kiss, G. K. 2013. 'Társadalmi részvételi eszközök értékelése környezeti ügyekben.' PhD dissertation, Corvinus University, Budapest.

KVVM. 2008. 'A magyar Környezetvédelmi és Vízügyi Minisztérium álláspontja a Heiligenkreuzba tervezett hulladékégető környezeti hatástanulmányával (к $\mathrm{H}$ T) kapcsolatban folyó Espoo-i egyezmény szerinti eljárás keretében.' http://www.kvvm.hu/cimg/documents/Hivatalos _magyar_allaspont_20080326.pdf

Lányi, A. 2012. 'Fenntarthatóság és közpolitika’ In Cselekedj lokálisan! Társadalmi részvétel környezeti ügyekben, edited by A. Pánovics and V. Glied, 9-31. Pécs: Publikon.

Lebensministerium. 2009. Thermische Abfallbehandlung in Österreich: Zahlen, Daten, Fakten. 2nd ed. Vienna: Lebensministerium.

Major, L. 2012. 'A környezeti nevelés szerepe a környezettudatos magatartás formálásában.' Iskolakultúra 9:67-79. 
Motherway, B. 2003. 'Public Involvement in Environmental DecisionMaking in Ireland.' Working Paper, The Policy Institute, Dublin.

Nárai, M., and A. Reisinger. 2016. Társadalmi felelösségvállalás és részvétel: a lokális és területi közösségi folyamatokban. Budapest and Pécs: Dialóg Campus.

Newman, J., and E. Tonkens. 2011. 'Active Citizenship.' In Participation, Responsibility and Choice, edited by J. Newman, and E. Tonkens, 179-200. Amsterdam: Amsterdam University Press.

Ozer, E. J. 2007. 'The Effects of School Gardens on Students and Schools: Conceptualization and Considerations for Maximizing Healthy Development.' Health Education \& Behavior, 34 (6): 846-63.

Ratcliffe, M. M. 2007. 'Garden-Based Education in School Settings: The Effects on Children's Vegetable Consumption, Vegetable Preferences and Ecoliteracy.' PhD dissertation, Tufts University, Medford, M A.

Reisinger, A. 2009. 'Részvételi demokrácia és társadalmi részvétel: elméleti megközelítések.' Civil Szemle 4:5-23.

— 2010. 'Társadalmi részvétel a helyi fejlesztéspolitikában: különös tekintettel a civil/nonprofit szervezetek szerepére' PhD dissertation, Széchenyi István University, Győr.

— 2017. 'Az aktív állampolgárság: fogalmi rendszer és kutatási koncepció.' In Új Nemzeti Kiválóság Program 2016/17 Tanulmánykötet, 138-48. Győr: Széchenyi István Egyetem.

RVH. 2009. “Thermische Reststoffverwertungsanlage” in der KG. Heiligenkreuz im Lafnitztal.' http://www5.umweltbundesamt.at/uvpdb/ docs/Bescheide/ThermReststoffverwertungsanlage_Heiligenkreuz/ Genehmigungsbescheid.pdf

Subramaniam, A. 2002. 'Garden-Based Learning in Basic Education: A Historical Review. Monograph, Summer, 1-12.

Wei, K. M. 2013. 'Garden-Based Learning: The Rationale, the Purpose, the Function.' https://www7.nau.edu/itep/main/SGardn/docs/About/ Garden-based_learning.pdf

Woki, Z. 2015. Szentgotthárdi csata a hulladékégető ellen. Gencsapáti: Szülöföld Könyvkiadó.

Yueh, M. 2007. 'Introducing a New Subject: The Case of Environmental Education in Taiwanese Junior High Schools.' PhD dissertation, University of Waikato, Hamilton. 



\section{Modern Trends in Chinese Foreign Direct Investment in Africa: An oLI Approach}

Henri Bezuidenhout

North-West University, South Africa

henri.bezuidenhout@nwu.ac.za

Ewert P. J. Kleynhans

North-West University, South Africa

11289570@nwu.ac.za

This study evaluates the subtle differences that the various types of foreign direct investment (FDI) of China in Africa offers, as revealed by the data, using the 'Ownership, Location and Internalisation Advantages' oli approach. Chinese FDI is analysed using source country comparisons, sectoral comparisons and an investigation of Chinese FDI practices. Data visualisation techniques and analyses infer similarities and differences between Chinese and other investors in Africa. These alternative methods are driven by the nature of the available data and its resulting statistical possibilities. The significance of this study is that it disambiguates the available data and compares along theory. Many stylised facts are assumed concerning Chinese FDI; this study, however, quantifies and tests these assumptions. The results show that China follows investment patterns of other investors, although heavily skewed towards oil, coal and gas, and other resource sectors. China otherwise tends to invest in medium growth, diversified economies, predominantly Nigeria and Egypt; except in Ethiopia where investment in communications dominates; Cameroon where chemicals dominate; Angola where investments in real estate outperform investment in the coal, oil and gas; and in South Africa and Tanzania that have a more even spread between sectors compared to the rest of the continent. Key Words: foreign direct investment, FDI, Africa, China, OLI, eclectic paradigm

JEL Classification: F 20, F 21, F 23

https://doi.org/10.26493/1854-6935.16.279-300

\section{Introduction}

The global economic expansion of China is growing in importance and is receiving more than its due share of attention, especially concerning trade and foreign direct investment (FDI) between China and other developing states. The global slowdown and structural change of the Chinese 
economy have highlighted Africa's dependence on FDI as the steep decline in FDI is affecting Africa (UNCTAD 2013, 40). The landscape in FDI to Africa has changed significantly during the preceding decade, as India and China are becoming significant investors in the continent (see http://www.fdimarkets.com). Chinese FDI has, however, incurred severe criticism from the Organisation for Cooperation and Development members, as they interpret Chinese involvement as a re-colonisation of Africa with the pure aim of exploitation (Claassen, Loots, and Bezuidenhout 2012, 11583).

China's possible impact on Africa is one of the most contemporary debated topics, with Sino-African relations increasing in significance since 200o. The main hypothesis of the article is to evaluate whether Chinese FDI in Africa is only resource based or contains other aspects of the eclectic paradigm of Dunning (1980). This is done through source country comparisons, sectoral comparisons and an investigation of Chinese FDI practices. The methodology is based on data visualisation techniques and analyses are used to infer similarities and differences between Chinese investors and the theoretical 'Ownership, Location and Internalisation Advantages' - OLI criteria. This alternative method is driven by the nature of the available data and its resulting statistical possibilities.

Under the leadership of Chinese president, Xi Jinping, Chinese policy towards Africa has, however, changed towards a more cooperative and co-developmental focus (Buckley 2013). At a major policy speech in Dar es Salaam, Tanzania, in 2013, he confirmed that Chinese cooperation with Africa will be 'people to people' focused, where China will ensure that Africans benefit from the relationship.

The Economist (2013a), a long-time critic of Chinese FDI in Africa, also recently published an article on the changing nature of Chinese FDI in Africa and its possible positive benefits. In two separate articles, they highlighted the slowdown of the Chinese economy and the resulting slowdown in resource-seeking FDI in Africa. Furthermore, a shift in Chinese attitudes focuses on Africa as a place to do business rather than a place to merely acquire resources.

The Economist (2013b) also highlights changing African attitudes toward Chinese FDI and towards China. Africa is becoming more assertive and focused on harnessing benefits from FDI, while Africans are viewing China more and more as a competitor, or even a collaborator, rather than a supplier of aid.

This study aims to investigate Chinese FDI in Africa at a country and 
sectoral level in order to gain a firmer understanding of the nature of Chinese FDI in Africa and to deduce conclusions on the possible effects thereof. The approach will be according to the eclectic FDI theory. Chinese FDI flows into Africa between 2003 and 2012 are examined with a view to verify the changing trends suggested. The significance of this study lies in the fact that it actually disambiguates the available data and compares it with theory. Many stylised facts are assumed concerning Chinese FDI; this study quantifies and tests these assumptions and evaluates the benefits sought by China from its FDI in Africa. The subtle differences that the various types of foreign direct investment (FDI) of China in Africa offer, which are revealed by the data, are also investigated.

\section{FDI in Africa}

The United Nations Conference on Trade and Development (UnCTAD) provides a thorough overview of basic FDI figures in Africa. FDI inflows to Africa were US\$50 billion in 2012, although Africa still receives less than $5 \%$ of the global FDI. While FDI increased in North, East and Central Africa, West and Southern Africa saw declines (UNCTAD 2013, 40). All currency in this article is noted in us dollar.

The rates of return on investment in Africa have on average dropped substantially since 2008 , to pre-2005 levels, while re-invested earnings from 2008 to 2012 have increased substantially (UNCTAD 2013, 33-4). This can be seen as the result of global economic movements and economic declines in the home country, especially the traditional partners of Europe and North America.

South Africa is listed among the top 20 prospects for FDI according to international standards of investment promotion (UNCTAD 2013, 23). It should be noted that many African countries are not on the list. The absence of African countries from the list is not surprising as the level of development in most African countries does not enable high levels of investment promotion facilitation in tandem with the negative image that the African countries hold globally.

Figures of 2011 and 2012 also predict a shift towards African consumers, and local manufacturing in Africa is moving towards FDI and away from the traditional investment in resource sectors (UNCTAD 2013, 40-2). This article will show that Chinese firms are orientating themselves strategically as development partners of African markets for future growth.

FDI inflows into Africa during the first decade of the third millennium (2003-2012) are illustrated in figure 1. After a significant growth phase 


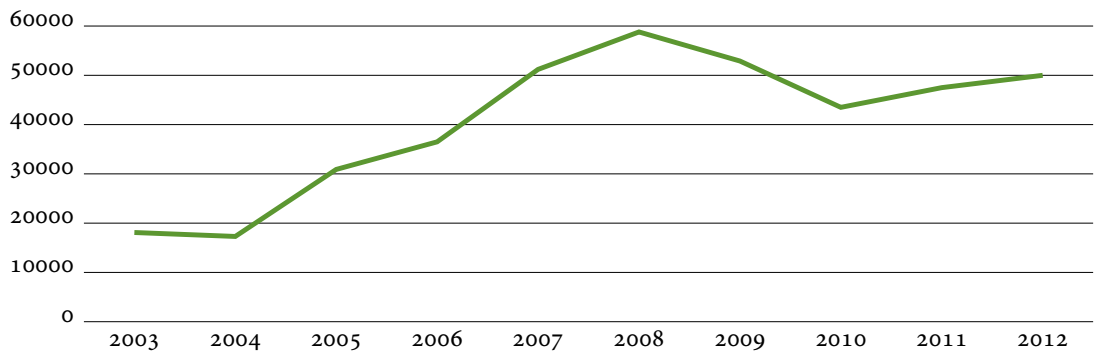

FIGURE 1 FDI Inflows into Africa 2003 to 2012 (million USD, based on data from http://unctad.org)

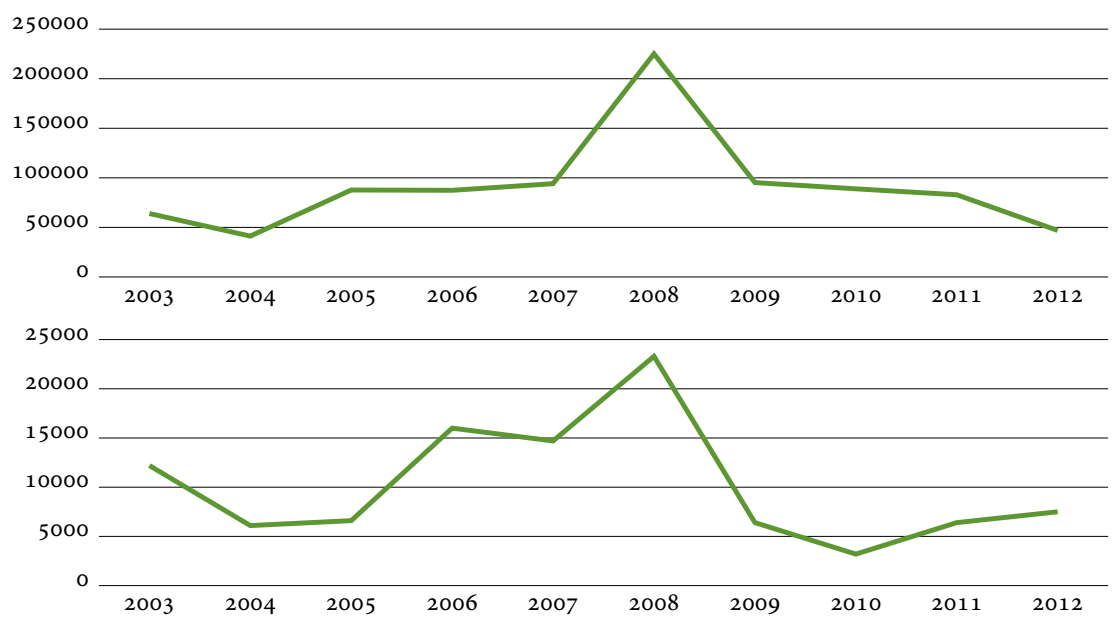

FIGURE 2 FDI into Africa 2003-2012: Greenfields (top) versus M\&AS (bottom) (million UsD, based on data from http://www.fdimarkets.com and https://zephyr2.bvdep.com)

from 2004 to 2008 , there was a steep decline until 2010, after which a slight recovery has occurred. The slight increase from 2011 to 2012 only occurs due to merger and acquisition ( $M \& A$ ) activities, as Greenfields FDI dropped to just above 2004 levels; where Greenfields FDI refer to new business ventures (UNCTAD 2013, 40).

The trends in terms of mergers and acquisitions ( $M \& A$ ), as well as Greenfields FDI are reflected in figure 2. The decline in Greenfields in 2012 as opposed to the increase of M\&A activity from 2010 is highlighted in the comparison.

Mergers and acquisitions form a relatively small percentage of FDI in Africa of only $8 \%$ and are concentrated around the more developed economies of Africa, such as South Africa and Egypt (Bezuidenhout, 


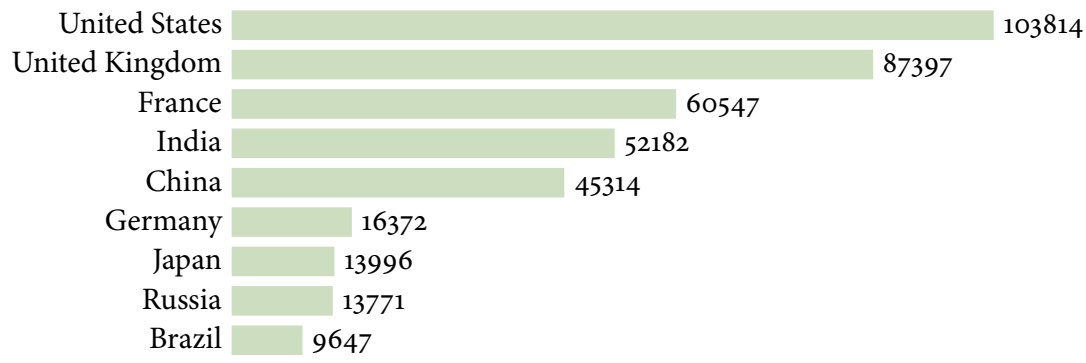

FIGURE 3 Major Source Countries for Greenfields FDI into Africa (million USD; based on data from http://www.fdimarkets.com)

Cloete, and Claassen 2014, 3). This study will therefore focus on Greenfield FDI, as Chinese FDI through M\&AS was limited to only 11 deals during the period, according to Bureau van Dijk (see https://zephyr2 .bvdep.com).

A breakdown and comparison of the major investors in Africa between 2003 and 2012, indicating Greenfields FDI, are provided in figure 3. The United Arab Emirates, the largest investor in Africa, is omitted from this graph because they focus mostly on the real estate and oil sectors of the Middle East and North African (MENA) countries (see http://www.fdimarkets.com). The United States of America (USA) is by far the largest investor in Africa, followed by the historical colonial powers of the United Kingdom and France. FDIs from India and China have risen to the level where they are jointly the size of the USA, while that of countries such as Brazil and Russia have grown to equal Japan and Germany. UNCTAD $(2013,40)$ also highlights the growth of FDI by developing African economies.

Considering the relative size of Greenfields FDI to recipient countries in Africa, the MENA countries form a distinctive group as opposed to the varied pattern across Sub-Saharan Africa (s A A). In ss A, four groupings can be discerned, namely Nigeria, South Africa and Angola as the largest recipients of FDI, Ghana and Mozambique as the second tier, the East African cluster of Uganda, Kenya and Tanzania and lastly, the rest of the ss A countries.

The breakdown of Greenfields FDI in Africa by sector from 2003 to 2012 compared to the inflows from 2008 to 2012 is provided in table 1. Notably, most sectors remain at their relative size to the others. There is also a severe skewedness toward FDI in the real estate, metals and coal, oil and natural gas sectors that is highlighted by the large percentage share 
TA BLE 1 Recipient Sectors for Greenfields FDI into Africa (US\$ million)

\begin{tabular}{|c|c|c|c|c|}
\hline \multirow[t]{2}{*}{ Sector } & \multicolumn{2}{|c|}{ FDI by sector (2003-2012) } & \multicolumn{2}{|c|}{ FDI inflow (2008-2012) } \\
\hline & (1) & (2) & (1) & (2) \\
\hline Coal, oil and natural gas & $366,027.91$ & 41.3 & $210,116.25$ & 40.3 \\
\hline Real estate & $168,459 \cdot 36$ & 19.0 & $96,668.79$ & 18.6 \\
\hline Metals & $117,955.53$ & $13 \cdot 3$ & $60,603.05$ & 11.6 \\
\hline Communications & $44,219.19$ & 5.0 & $30,821.03$ & 5.9 \\
\hline Chemicals & $29,437.56$ & $3 \cdot 3$ & $17,599.27$ & 3.4 \\
\hline Hotels \& tourism & $28,367.20$ & 3.2 & $13,931.40$ & 2.7 \\
\hline Alternative/renewable energy & $23,680.55$ & 2.7 & $19,233.41$ & 3.7 \\
\hline Food \& tobacco & $17,842.04$ & 2.0 & $13,070.48$ & 2.5 \\
\hline Building \& construction materials & $17,377.18$ & 2.0 & $12,092.63$ & 2.3 \\
\hline Automotive OEM & $13,682.80$ & 1.5 & $9,015.69$ & 1.7 \\
\hline Transportation & $12,039 \cdot 36$ & 1.4 & $6,066.86$ & 1.2 \\
\hline Financial services & $10,651.01$ & 1.2 & $7,103.14$ & 1.4 \\
\hline Warehousing \& storage & $6,574.50$ & 0.7 & $2,746.60$ & 0.5 \\
\hline Business services & $6,283.82$ & 0.7 & $4,094.17$ & 0.8 \\
\hline Leisure \& entertainment & $6,183.80$ & 0.7 & $5,629.10$ & 1.1 \\
\hline Software \& IT services & $5,485.00$ & 0.6 & $3,956.40$ & 0.8 \\
\hline Minerals & $4,333.14$ & 0.5 & $2,297.10$ & 0.4 \\
\hline Beverages & $4,235.87$ & 0.5 & $3,119 \cdot 39$ & 0.6 \\
\hline Paper, printing \& packaging & $3,852.72$ & 0.4 & $2,854.62$ & 0.5 \\
\hline Total & 886688.54 & 100.0 & $521,019 \cdot 38$ & 100.0 \\
\hline
\end{tabular}

NOTES Based on data from http://www.fdimarkets.com.

of the sectors. This gives rise to the speculation about resource exploitation by multinationals (MNES) in Africa at the expense of local development.

\section{Chinese FDI in Africa}

After joining the w To in 2001, China officially allowed private foreign investment in FDI projects with its 'open door' policy (Claassen, Loots, and Bezuidenhout 2012, 11583). The Ministry of Commerce (see http://english.mofcom.gov.cn) in China is the custodian of Chinese FDI data. Their most recent official figures indicate that U $\$ 2.52$ billion of Chinese FDI flowed to Africa during 2012, with a total Chinese FDI stock 


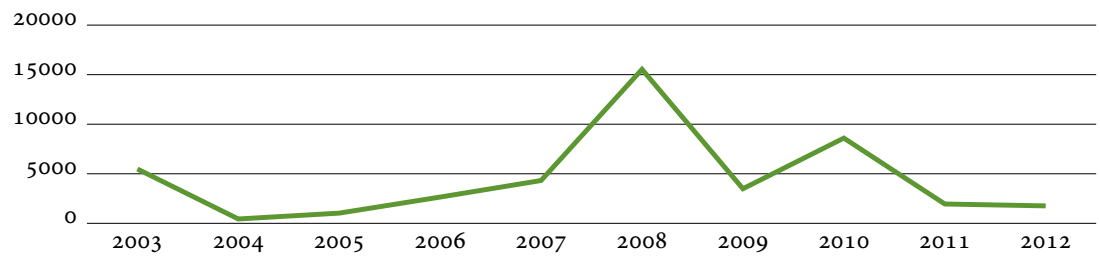

FIgURE 4 Chinese Greenfields FDI in Africa (million USD, based on data from http://www.fdimarkets.com)

in Africa of US\$21.23 billion. It estimates that approximately 2 ooo Chinese firms are active in 50 African countries.

These figures contradict the figures of the fDi Markets database and that of Bureau van Dijk as they only show Chinese firms being active in 27 African countries through FDI (see http://www.heritage.org). This discrepancy is explained by the Chinese Ministry of Commerce (see http://english.mofcom.gov.cn) using all foreign investment as standard, while fDi Markets use the international standard as set by the Organisation for Cooperation and Development benchmark definition of FDI, which requires a minimum $10 \%$ stake or direct management voice (Organisation for Cooperation and Development 2008). Resultantly, to adhere to international standards, the fDi Markets database is utilised as a source in this study as it also allows for comparison between countries and recorded deals are independently verifiable.

As shown in figure 3 , China has risen to become a prominent investor in Africa. According to figure 4, Chinese FDI in Africa generally follows the overall trend as was shown in figure 2. The similarity in the pattern between the total FDI inflows and Chinese FDI is reflected by the smoother increase between 2004 and 2007, a spike in 2008 and a smaller spike in 2010. According to FDI Markets (http://www.fdimarkets.com), 2012 saw U $\$ 1764$ million total Greenfields FDI in Africa and a total Chinese Greenfields FDI of US\$45 313 million. Greenfields FDI makes up more than $95 \%$ of Chinese FDI in Africa (see http://www.fdimarkets.com and https://zephyr2.bvdep.com).

A snapshot of the destination countries for Chinese Greenfields FDI in Africa is provided in figure 6. Nigeria, Angola and Algeria are the major recipients of Chinese FDI. It is noteworthy that FDI in Angola primarily went into the real estate sector and not the coal, oil and natural gas sector, as one would expect, as is the case with Algeria and Nigeria.

Furthermore, the research results indicate that South Africa and Kenya 


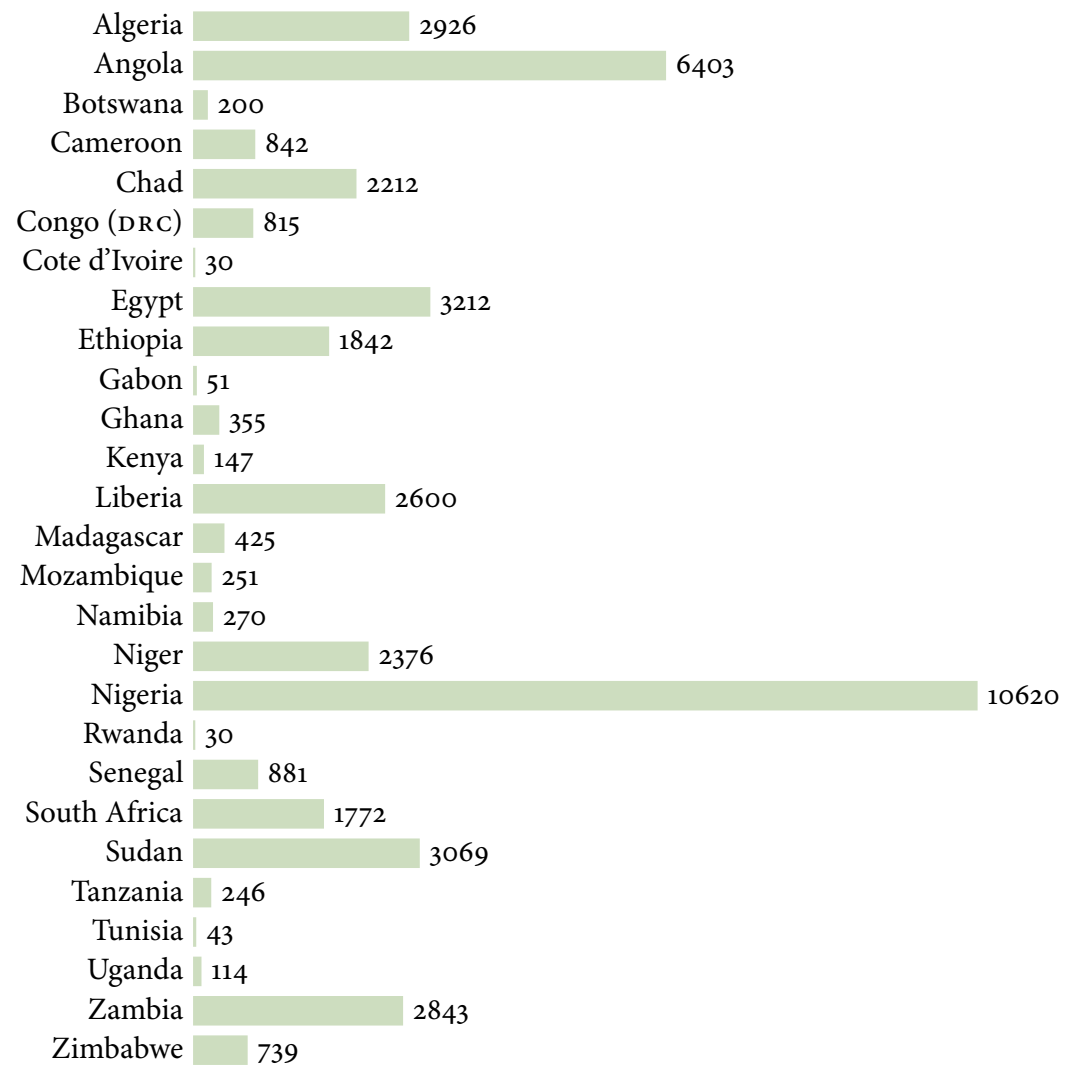

figure 5 Chinese Greenfields Fdi in Africa, Destination Countries (million USD, based on data from http://www.fdimarkets.com)

are the only countries that receive a high percentage of diverse sectoral investments (noting to 'Greenfields FDI'). Also noteworthy is the dominance of the communications sector in Ethiopia, as well as chemicals in Tanzania and Cameroon. Overall, there is a strong dominance of the resource sectors and real estate.

\section{Literature Review}

In order to investigate Chinese FDI in Africa critically, this study links with the 'Ownership, Location and Internalisation Advantages Model,' known as the OLI model of Dunning (1980, 9), which focuses on ownership, location and internalisation advantages (OLI). This model was invented by Dunning in the 1980 os and has been widely used as foundation theory in FDI studies ever since. The eclectic paradigm or OLI frame- 
work was first developed by Dunning (1980) in his study 'Towards an Eclectic Theory of International Production: Some Empirical Tests.' Using the eclectic paradigm and its subsequent determinants, FDI can be categorised and the behaviour of multinational enterprises (MNES) can be evaluated (Blonigen 2005, 383). MNE activities can be investigated along the oli categories and a definitive argument can be made about their investment focus, as well as the theoretical impact the FDI will have on the recipient economies.

The first level of the OLI model categorises FDI according to the advantages gained by multinational enterprise (MNE) investing in a foreign market. These include ownership, location and internalisation advantages (Dunning and Lundan 2008). Ownership advantages reflect on the comparative advantage of the firm. If it has a greater comparative advantage, it will invest. Location advantages focus on the gains of comparative advantages through acquiring resources and market position. Internalisation advantages are the advantages gained using own production and internal specialisation (Dunning and Lundan 2008).

From an MNE perspective, Dunning (1981) groups these advantages according to 'OLI' as follows: (1) Firms that have ownership of firmspecific assets, which will determine whether it will be advantageous for them to invest; (2) firms that have a location advantage and will only invest if it is more cost efficient for the firm to exploit firm-specific assets abroad rather than only in the home country; and (3) firms that will also have an internalisation advantage and it must be more advantageous for the firm to use its assets internally rather than contracting with other firms in the host country.

UNCTAD (2000) and subsequent work by Dunning and Lundan (2008) further interpret MNE FDI motives as the result of the four categories based on the original OLI model. 'Market-seeking FDI' occurs when an MNE wants to expand the consumer market for its product (goods and/or services) to new consumers. 'Resource-seeking FDI' focuses on the acquisition of resources or access to resources. These include natural resources and production inputs, such as production materials and labour (Slaughter 2002). 'Strategic-asset-seeking FDI' is the result of the MNES' mandate to create shareholder wealth by acquiring tangible or intangible assets to enhance its strategic comparative advantage. These include technologies and intellectual property, as well as regional headquarters (Krueger and Strauss 2014). 'Efficiency-seeking FDI' seeks to enhance firm productivity through cost minimisation or economies of scale in 
TAB LE 2 Typology of FDI and Incentives

\begin{tabular}{|c|c|c|c|}
\hline Resource-seeking & Market-seeking & Strat. asset-seeking & Efficiency-seeking \\
\hline $\begin{array}{l}\text { Location of: natural } \\
\text { resources, raw ma- } \\
\text { terials low-skilled } \\
\text { labour, agglomera- } \\
\text { tion benefits }\end{array}$ & $\begin{array}{l}\text { Market potential: } \\
\text { market dimensions, } \\
\text { income per capita, } \\
\text { customer-specific } \\
\text { preferences, kind of } \\
\text { goods and services } \\
\text { to be provided }\end{array}$ & $\begin{array}{l}\text { Acquiring strategic } \\
\text { assets: brands and } \\
\text { market positioning, } \\
\text { expertise, technol- } \\
\text { ogy, distribution } \\
\text { networks, human } \\
\text { capital }\end{array}$ & $\begin{array}{l}\text { Lower costs: mostly } \\
\text { export oriented, } \\
\text { availability of skills } \\
\text { at low costs, close } \\
\text { to markets, low } \\
\text { relocation costs }\end{array}$ \\
\hline $\begin{array}{l}\text { Low response to } \\
\text { both tax and non- } \\
\text { tax incentives }\end{array}$ & $\begin{array}{l}\text { Low response to } \\
\text { both tax and non- } \\
\text { tax incentives }\end{array}$ & $\begin{array}{l}\text { Low response to } \\
\text { both tax and non- } \\
\text { tax incentives }\end{array}$ & $\begin{array}{l}\text { High response to } \\
\text { tax and non-tax } \\
\text { incentives }\end{array}$ \\
\hline $\begin{array}{l}\text { FDI drivers based } \\
\text { on other factors } \\
\text { than incentives }\end{array}$ & $\begin{array}{l}\text { All firms need to be } \\
\text { treated equally }\end{array}$ & $\begin{array}{l}\text { FDI driven by loca- } \\
\text { tion }\end{array}$ & $\begin{array}{l}\text { Affects firms' com- } \\
\text { petitive edge }\end{array}$ \\
\hline
\end{tabular}

NOTES Based on James (2013).

global production networks (GPNS). It can also be described as the rationalising of the firm's production structure or organisational structure (Sachwald 2005).

A typology of FDI, differentiating between tax and non-tax incentives to MNES by James (2013), is provided in table 2. This allows for a more indepth assessment of the four FDI categories, namely resource-seeking, market-seeking, strategic asset-seeking and efficiency-seeking. His analysis is based on responses by MNES to these incentives by increased FDI. Although this study does not focus on incentives, the typology provides a significant overview of the four FDI categories.

UNCTAD (2010) and Krueger and Strauss (2014) provide a further synthesis of the determinants of FDI according to the OLI theory. Added are categories that influence FDI as a whole, but handle the different categories in different manners. These variables relate to policy frameworks and business facilitation. Table 3 provides an overview of the policy framework and the business facilitation variables. The area of business facilitation is highly relevant for efficiency-seeking FDI, as is seen in table 2.

They also provide a more concrete way of studying the FDI categories in terms of economic variables. An overview of the economic variables, which form the determinants of FDI, is provided in table 4 .

When it comes to the effects of FDI in each of the four categories, there is a great difference in results and opinions. The OLI paradigm focuses 
TABLE 3 FDI: Policy and Facilitation Variables

\begin{tabular}{|c|c|}
\hline Polic & \\
\hline $\begin{array}{l}\text { Economic, political and social stability; Rules } \\
\text { regarding entry and operations; Standards of } \\
\text { treatment of foreign operations; Policies on } \\
\text { functioning and structure of markets (esp. com- } \\
\text { petition, M\& A; and corporate governance); } \\
\text { Privatisation policy; Trade policy (tariffs and } \\
\text { NT B s) and coherence of F DI and trade poli- } \\
\text { cies; Tax policy; Good governance; Protection } \\
\text { of property rights (including intellectual prop- } \\
\text { erty); Industrial and regional policies; develop- } \\
\text { ment of competitive clusters; Stable exchange } \\
\text { rates. }\end{array}$ & $\begin{array}{l}\text { Investment promotion (incl. image } \\
\text { building, actions to reduce infor- } \\
\text { mation asymmetries); Investment } \\
\text { incentives (e.g. fiscal, financial and } \\
\text { regulatory); Technical services, in- } \\
\text { cluding: hassle costs (e.g. related } \\
\text { to corruption and administrative } \\
\text { efficiency), social amenities (e.g. } \\
\text { bilingual schools and quality of life), } \\
\text { after-investment services, and ser- } \\
\text { vices to centralise procedures and } \\
\text { information. }\end{array}$ \\
\hline
\end{tabular}

NOTES Adapted from Vale Columbia Center on Sustainable International Investment (2013).

mainly on value added and more productive chains, knowledge and skills spillovers, changing consumer behaviour, enhanced good governance, infrastructure development and economic growth (Dunning and Lundan 2008, 319).

Although most authors focus on the benefits of FDI for developing countries, the positive effects are directly linked to policies and institutions to facilitate the linkages and spillovers (Kosack and Tobin 2006, 205). Receiving FDI is not a guarantee for actual economic benefit; careful planning and responsible governance are required to materialise these gains.

In the following section, the available data as determinants, as well as the limitation on analysis placed by the data, will be discussed.

\section{Data and Limitations}

Data for Chinese FDI in Africa are not regularly accessible. The Financial Time's fDi Markets database for Greenfields FDI is used in this study as a source of sector-specific Chinese FDI in African countries. The data covered by the Financial Times database is compiled from FDI deals between 2003 and 2012 for all African countries.

The main limitations of using the fDi Markets database are that some deals are not recorded due to a specific lack of information and subsequently cannot be compared to FDI figures published by UNCTAD, the World Bank and the International Monetary Fund (IMF). However, the data published by them are recipient country totals that do not break 
TABLE 4 The Determinants of FDI

\begin{tabular}{|c|c|c|c|}
\hline Resource-seeking & Market-seeking & Strat. asset-seeking & Efficiency-seeking \\
\hline $\begin{array}{l}\text { Access to raw mate- } \\
\text { rials; Access to natu- } \\
\text { ral resources; Access } \\
\text { to low-skilled labour }\end{array}$ & $\begin{array}{l}\text { Market size; Per } \\
\text { capita income; Mar- } \\
\text { ket growth; Access } \\
\text { to regional and } \\
\text { global markets; } \\
\text { Country-specific } \\
\text { consumer prefer- } \\
\text { ences; Structure of } \\
\text { markets }\end{array}$ & $\begin{array}{l}\text { Access to skilled } \\
\text { labour; Access to } \\
\text { new competitive } \\
\text { advantages; Tech- } \\
\text { nological and other } \\
\text { created assets; Avail- } \\
\text { ability of and access } \\
\text { to strategic infras- } \\
\text { tructure }\end{array}$ & $\begin{array}{l}\text { Cost of resources } \\
\text { and assets listed } \\
\text { under resource- } \\
\text { or asset-seeking; } \\
\text { Other input costs, } \\
\text { i.e. transportation } \\
\text { and communication } \\
\text { costs; Costs of other } \\
\text { intermediate prod- } \\
\text { ucts; Membership } \\
\text { of a regional inte- } \\
\text { gration agreement; } \\
\text { Low-cost unskilled } \\
\text { or skilled labour; } \\
\text { Different compar- } \\
\text { ative advantages of } \\
\text { countries; Better de- } \\
\text { ployment of global } \\
\text { resources }\end{array}$ \\
\hline
\end{tabular}

Notes Adapted from Vale Columbia Center on Sustainable International Investment (2013).

down to sector level or source country information. Lastly, it should be noted that not all countries received Chinese FDI, not all received FDI annually and not all received FDI into every sector. The vast majority of deals are in the coal, oil and natural gas and metals sectors.

These limitations limit the application of econometric techniques, as the short sample period and irregular investment intervals per country and sector (which generates missing values) will render the time series sample size too small for satisfactory analysis. A base investigation was therefore conducted, based on a graphical analysis to establish a basis for future analysis, as more data becomes available that will satisfy the statistical requirements.

Data on Chinese investment in 27 African countries for the decade 2003 to 2012 were used. It is worth noting that, after 2008, only Rwanda, Gabon and Tanzania, of these, did not receive any Chinese FDI.

A comparison of the destination countries and sectors of Greenfields Chinese FDI in Africa is made in figure 6. Only South Africa and Egypt received highly diverse investments, and the coal, oil and natural gas as well as the communications sectors are the only sectors 


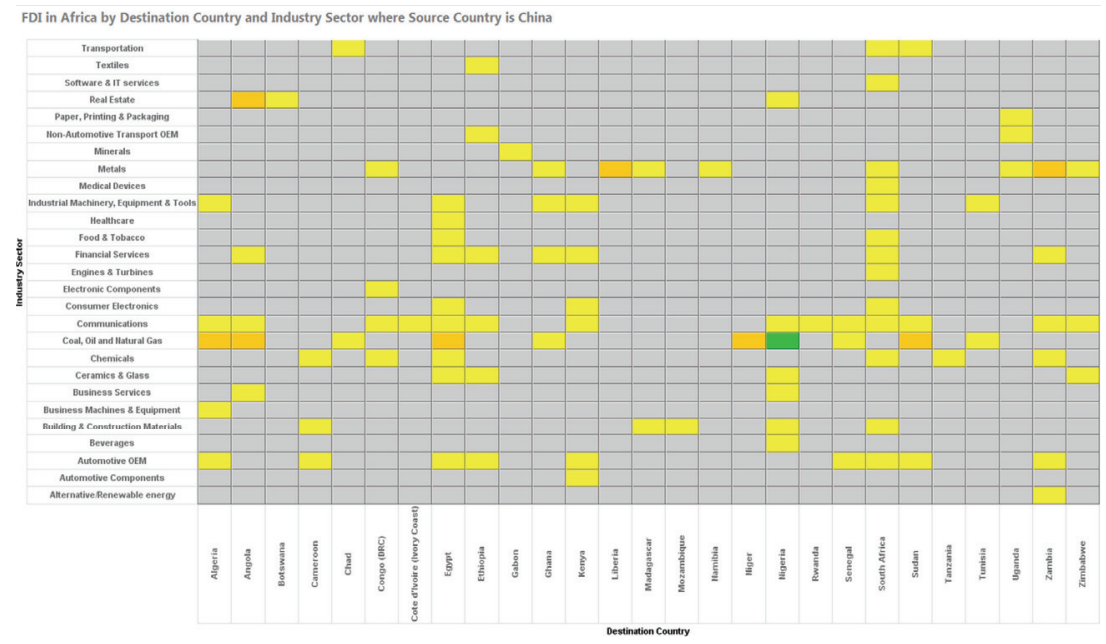

FIGURE 6 Overview of Chinese Greenfields FDI in Africa 2003 to 2012 by Host Country and Sector (based on data from http://www.fdimarkets.com)

that have a wide dispersion in terms of destination countries. For determinant comparisons, the World Bank Development Indicators (see http://data.worldbank.org) were used, as well as the United Nations Development Program (UNDP) Human Development Index (HDI) (see http://hdr.undp.org). It should be noted that World Bank data are not equally available for the destination countries and as a result the latest available values were always used. In cases where averages are used, averages over the sample period 2003 to 2012 were taken.

\section{The Research Methodology and Empirical Results}

This study investigates Chinese Greenfields F DIS in terms of country and sectoral comparisons and Chinese FDI practices. Data visualisation techniques and analyses are used to infer similarities and differences between Chinese and other investors in Africa. This method was chosen for the special information statistical possibilities it may yield and because of data restrictions. The detail on the graphs of this analysis might not be very clear in this format of the journal, but the aim is to infer and indicate general trends.

In order to disambiguate Chinese FDI in Africa, each of the four OLI categories were investigated in terms of the major determinants listed in the literature. The exception to this is resource-seeking FDI. Total FDI and the total FDI minus resource sectors are used. FDI minus resource 
sectors focuses on the FDI that is not resource based to evaluate it against the OLI criteria. If it shows OLI behaviour it shows that Chinese FDI is not only resource seeking, but also follows oli behaviour. Only the strongest relationship in each category was reported, although the general trend is the same for all sets in that the same relationship can be seen between the two.

The following section discusses the research findings in terms of resource-seeking, market-seeking, efficiency-seeking and strategic assetseeking FDI.

\section{RESOURCE SEEKING}

In this category, the total FDI inflows from 2003 to 2012 were compared to the total FDI inflows from 2003 to 2012 minus the major resource sectors of coal, oil and natural gas, metals, minerals and tobacco and food. Logically, if FDI in countries is non-resource seeking, they should rank much higher in the rankings than with the resources included. Similarly, if the FDI focus was solely resource driven, they should have had a steep decline in the rankings.

The results of total Greenfields FDI compared to the total FDI minus the resource sectors are listed in table 5. Liberia, Niger, Namibia, Sudan, Senegal and Gabon all show steep declines leading to the conclusion that the focus in these countries is mainly resource seeking. Ghana is on the borderline, but is still considered mainly resource driven.

In contrast, Ethiopia, South Africa, Cameroon, Mozambique, Cote d'Ivoire, Rwanda, Zimbabwe, Tanzania, Botswana and Kenya all show steep increases in the ranking, implying that the focus in these countries is mainly non-resource driven. Observations made are therefore confirmed, especially in the case of Ethiopia, Cameroon, South Africa, Tanzania and Kenya.

The rest of the countries all remain approximately at the same level in the rankings. Noteworthy are Nigeria, Angola, Algeria (the oil countries) and the Democratic Republic of Congo (DRC), all known to be highly priced in resource-seeking FDI regions. This implies that these countries receive a relatively broader spectrum of FDI as indicated in figure 6 .

The comparison between total FDI and agricultural land yields a positive relationship, as illustrated in figure 7 . This confirms the findings of Claassen, Loots, and Bezuidenhout (2012) and suggests that Chinese firms are pursuing investments in future Chinese food security. The results are summarised in table 6 and discussed below. In summary, it can 
TABLE 5 Chinese Greenfields FDI in Africa: Country Ranking with and without Resource Sectors

\begin{tabular}{|c|c|c|c|c|}
\hline (1) & $(2)$ & (3) & (4) & (5) \\
\hline Nigeria & Angola & Congo (DRC) $(+3)$ & Ethiopia $(+9)$ & Liberia $(-20)$ \\
\hline Angola & Ethiopia & Tunisia $(+2)$ & South Africa $(+7)$ & Niger $(-20)$ \\
\hline Egypt & Nigeria & Angola $(+1)$ & Cameroon $(+7)$ & Namibia $(-10)$ \\
\hline Sudan & South Africa & Algeria $(+1)$ & Mozambique $(+7)$ & Sudan $(-9)$ \\
\hline Algeria & Cameroon & Zambia (+1) & Cote d'Ivoire $(+7)$ & Senegal $(-6)$ \\
\hline Zambia & Egypt & Uganda $(+1)$ & Rwanda (+7) & Gabon $(-5)$ \\
\hline Liberia & Algeria & Madagascar (=) & Zimbabwe (+6) & Ghana (-4) \\
\hline Niger & Zambia & Chad $(-1)$ & Tanzania $(+6)$ & \\
\hline Chad & Zimbabwe & Nigeria $(-2)$ & Botswana $(+6)$ & \\
\hline Ethiopia & Chad & Egypt $(-3)$ & Kenya (+5) & \\
\hline South Africa & Congo (DRC) & & & \\
\hline Senegal & Mozambique & & & \\
\hline Cameroon & Sudan & & & \\
\hline Congo (DRC) & Tanzania & & & \\
\hline Zimbabwe & Botswana & & & \\
\hline Madagascar & Madagascar & & & \\
\hline Ghana & Kenya & & & \\
\hline Namibia & Senegal & & & \\
\hline Mozambique & Cote d'Ivoire & & & \\
\hline Tanzania & Rwanda & & & \\
\hline Botswana & Ghana & & & \\
\hline Kenya & Uganda & & & \\
\hline Uganda & Tunisia & & & \\
\hline \multicolumn{5}{|l|}{ Gabon } \\
\hline \multicolumn{5}{|l|}{ Tunisia } \\
\hline \multicolumn{5}{|l|}{ Cote d'Ivoire } \\
\hline Rwanda & & & & \\
\hline
\end{tabular}

NOTES Column headings are as follows: (1) total FDI, (2) FDI without resource sectors, (3) small differences, (4) large positive difference, (5) large negative difference. Based on data from http://www.fdimarkets.com.

be concluded that, although there is a strong focus on resource-seeking FDI by Chinese firms, there is also a strong tendency towards a more diverse reasoning in their investments. The findings on the Greenfields FDIs minus resources in terms of three benefit seeking categories analysed against certain criteria are discussed in table 6. 


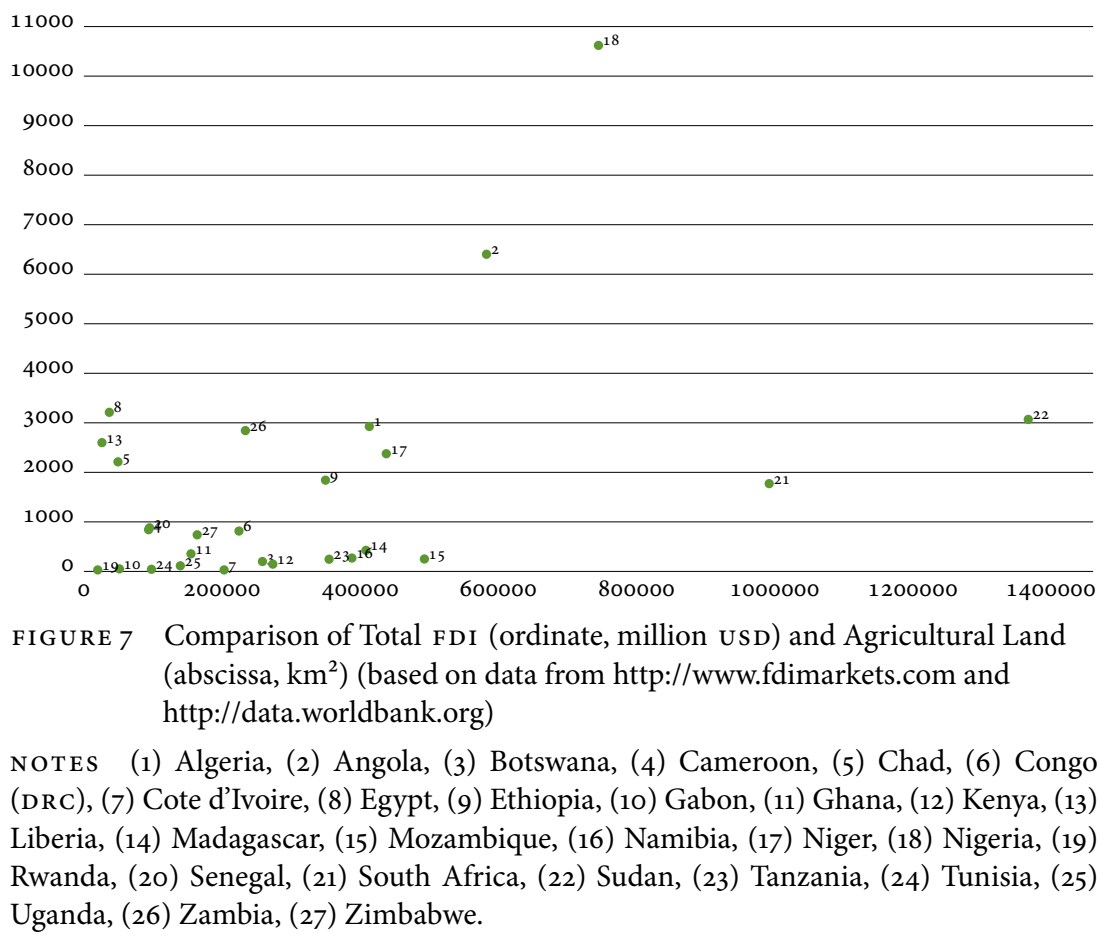

\section{MARKET SEEKING}

Market-seeking FDI is assessed by comparing FDI inflows with market size, per capita income, market growth and trade connectedness. Both total FDI and total FDI minus the resource sectors were evaluated. Total FDI minus resource sectors was reported, unless the FDI total is significantly more positive. The results are summarised in Table 6. When market size, as a factor of market seeking, is considered as the difference between total FDI and resources plus total population of the recipient countries, there seems to be a strong positive relationship between these variables, except in the case of Angola. There is also a strong positive relationship between total FDI minus the resource sectors, and per capita production and income (GDP) of the recipient countries. Here the only exceptions are in the case of a few outliers, such as Angola and Equatorial Guinea. The results of a comparison between total FDI minus the resource sectors and the average GDP growth for the recipient countries indicated that there is a positive relationship between Chinese FDI and 
TABLE 6 OLI comparison of Chinese Greenfields FDI Minus Resource Sectors in Africa

\begin{tabular}{llll}
\hline Criteria & $(1)$ & $(2)$ & $(3)$ \\
\hline Total population & Strong positive & & \\
GDP per capita & Positive & Positive & Positive \\
Average GDP growth & Positive & Positive & \\
Logistics performance index & Positive & Positive & Positive \\
Ease of doing business & Strong Positive & Strong positive & \\
Labour force & & Strong positive & \\
Liner shipping connect. index & & No sig. relation & No sig. relation \\
Mobile cellular subscription & Positive & Positive & Positive \\
Human development index & Positive & Positive & Positive \\
\hline
\end{tabular}

Notes Column headings are as follows: (1) market seeking, (2) efficiency seeking, (3) strategic asset seeking. Based on data from http://www.fdimarkets.com.

economies with high economic growth. Connectedness and trade were tested using the Logistics Performance Index (LPI) and an indicator of the ease of cost-effective shipping. A comparison between total FDI minus the resource sectors and the Logistics Performance Index (LPI) for the recipient countries revealed that although the overall LPI Index does not have any significant relationship, the ease of arranging cost-effective shipping does show a positive relationship. This indicates a mixture of efficiency-seeking and market-seeking FDI.

The major recipients of Chinese FDI is provided in table 5. The result does indicate a preference for 'gateway' countries, as Nigeria, Ghana, Ethiopia, Kenya, Egypt and South Africa that are all respectively viewed as the dominant countries in the respective regions of Africa.

Combining market size, market income, market growth, logistics and regional gateways provides a picture of a strong market orientation in Chinese FDI, which is not resource focused. This supports UnCTAD's assertion of a change in FDI behaviour towards the African consumer and shows that Chinese firms are strategically placing themselves in the African market for future business and growth. The following section reports on the empirical findings about efficiency seeking.

EFFICIENCY SEEKING

To test for efficiency-seeking FDI, the focus shifts to the costs involved in business and labour. Country-by-country data are nearly impossible 
to obtain for most countries and the focus was therefore on comparing total FDI and total FDI minus resource sectors with the World Bank Doing Business Index and the available labour force. The research results on efficiency seeking are also summarised in Table 6.

The individual relationships mirror most of the market-seeking relationships. For most of these relationships, the total FDI also shows a slightly better positive relationship than when the resource sectors are omitted. This suggests that even resource-seeking FDI has an efficiencyseeking component. Chinese firms will therefore rather invest in more efficient business environments than in more inefficient ones.

With the exception of Angola, there is a strong positive relationship between the size of the labour force and Chinese FDI. Total FDI minus resource sectors also provides stronger positive results than total FDI. This implies that the quality of the labour force is a strong consideration for Chinese firms.

The Liner Shipping Connectivity Index (LSCI) was also compared with total FDI minus the resource sector's yields. This comparison is done in order to further the results of the Logistics Performance Index (LPI) in the market-seeking FDI section. The relationship in this case is a much stronger positive relationship. This indicates that seeking efficiency is the main consideration in terms of trade connectedness.

In both total FDI and total FDI minus resource sectors, Chinese firms show a consistent behaviour of seeking efficient cost-saving FDI. The following section reports on the findings concerning strategic asset seeking.

\section{STRATEGIC ASSET SEEKING}

Strategic asset-seeking FDI is a more difficult category to test for on a macro-level, especially without firm-specific information. Mobile cellular connections given in Table 6 were used as a proxy to test for technology investment and connectedness, while the quality of life and skilled labour requirements were evaluated using the UNDP's HDI. The HDI also provided more information and background as a proxy for the availability of technology and the absorptive capacity of it by the country. The results of the LPI and LSCI also confirm that port infrastructure has a significant role to play.

When mobile cellular subscription was compared with the total FDI minus the resource sectors, the results show a strong positive trend in the relationship. The implication is that there is a strong correlation between Chinese FDI and the availability of technology in recipient countries, as 
indicated in Table 6. Under strategic asset-seeking F DI, the HDI was also tested to confirm whether the preference is towards more skilled or unskilled labour, and the results show a preference for better skilled labour markets.

When the Human Development Index (HDI) is compared to the total FDI minus the resource sector, the results revealed that, except for Angola, there is a general strong positive relationship between the variables. Chinese firms therefore prefer investing in countries with a higher quality of life, skilled labour and the availability of technology.

When it comes to Chinese FDI in Africa, excluding resources, there is a specific strong positive relationship with the determinants of strategic asset-seeking FDI. The following section summarises the research results of this study.

\section{Summary of Results}

This study differs from previous studies on the topic in that it investigated Chinese investment (FDI) in African countries quantitatively, considering the available data. It disambiguates the available data and made a unique contribution to the existing knowledge base, as it confirmed some stylised fact on Chinese FDI in Africa, while contradicting others, generating interesting and informative results

This study revealed that China is mostly following investment patterns of other investors, although heavily skewed towards oil, coal and gas, as well as other resource sectors. China otherwise tends to invest in medium growth, diversified economies, predominantly in Nigeria and Egypt. A specific exception is Ethiopia, where investment in communications dominates; Cameroon, where chemicals dominate; Angola, where Chinese investment in the coal oil and gas sector was outperformed by the real estate investments; and South Africa and Tanzania that have a more even spread between sectors than the rest of the continent.

Although there is a strong tendency towards resource-seeking FDI by Chinese firms, it can be concluded that there is also a strong tendency for more diverse reasoning in the investments, while a focus on food security is also confirmed.

Combining market size, market income, market growth, logistics and regional gateways indicates a strong market-seeking orientation in Chinese FDI that is not resource focused. This supports UNCTAD's assertion that a change in FDI behaviour towards the African consumer is in progress and that Chinese firms are positioning themselves strategi- 
cally in African markets for future business and growth. In both total FDI and total FDI minus resource sectors, Chines firms show a consistent behavioural tendency of seeking efficient cost-saving FDI. Ease of doing business, total labour force and the Liner Shipping Connectivity Index (LSCI) all show significant positive relationships with Chinese FDI. This confirms a local manufacturing element in all sectors, which is not only extraction based.

When Chinese FDI in Africa, excluding resources, is considered, there is a strong positive relationship with the determinants of strategic assetseeking FDI. Chinese firms invest more in countries with a higher quality of living, skilled labour and available technology.

\section{Conclusion}

This study analysed Chinese FDI in Africa based on the OLI framework of 'Ownership, Location and Internalisation Advantages.' Differentiating Chines FDI into the categories determined by FDI literature enables an understanding of the nature and reasoning behind the investment decisions of Chinese firms. This is especially important in light of continuing criticism in Western media regarding the motivation for Chinese investments in Africa as a new form of colonialism and exploitation.

Chinese FDI also shows strong elements of market-seeking, efficiencyseeking and strategic asset-seeking behaviour. It was shown that Chinese FDI in Africa follows global trends and, from a theoretical perspective, has a much broader scope than the sceptics focus on. Although a strong resource-seeking focus exists among Chinese FDI, very few countries experience only resource-seeking F DI. Elements of food security and longterm food production can also be verified.

Africa is set to reap the benefits of the developmental loans and infrastructure development along with the growth elements of FDI and its spillover effects. The focus on market-seeking, efficiency-seeking and strategic asset-seeking FDI will also transfer technologies and will lead to skill and productivity increases as well as a growing consumer base. If African countries manage this process well, to allow for competition and crowding in of local firms, Chinese FDI will make a great contribution towards the transformation of the economic landscape of Africa.

Chinese investment in Africa can therefore be seen as a long-termoriented economic presence. Chinese investment is also linked to inexpensive developmental loans and infrastructure development projects. The implication is that China is creating a future market for its products 
and its brands with a very long-term horizon. China has become a major player in FDI in Africa. They will remain a dominant force and may eventually even become the most dominant force.

\section{References}

Bezuidenhout, H., S. E. Cloete, and C. Claassen. 2014. 'The Determinants of Indian FDI in Africa: A Structural Equation Approach.' Journal of Economic and Financial Sciences 7 (3): 775-96.

Blonigen, B. A. 2005. 'A Review of the Empirical Literature on FDi Determinants.' Atlantic Economic Journal 33 (4): 383-403.

Buckley, C. 2013. 'China's Leader Tries to Calm African Fears of His Country's Economic Power'. The New York Times, 26 March.

Claassen, C., E. Loots, and H. Bezuidenhout. 2012. 'Chinese Foreign Direct Investment in Africa: Making Sense of a New Economic Reality'. African Journal of Business Management 6 (4): 11583-97.

Dunning, J. H. 1980. 'Toward an Eclectic Theory of International Production: Some Empirical Tests.' Journal of International Business Studies 11 (1): 9-31.

- 1981. International Production and the Multinational Enterprise. London: Allen and Unwin.

Dunning, J. H., and S. M. Lundan. 2008. Multinational Enterprises and the Global Economy. 2nd ed. Cheltenham: Edward Elgar.

James, S. 2013. Tax and Non-Tax Incentives and Investments: Evidence and Policy Implications. Washington, DC: World Bank.

Kosack, J., and J. Tobin. 2006. 'Funding Self-Sustaining Development: The Role of Aid, FDI and Government in Economic Success.' International Organization 60 (1): 205-43.

Krueger, R., and I. Strauss. 2014. 'Regional Integration as a Determinant of F DI?' African Development Bank Working Paper Series, African Development Bank, Abidjan.

Organisation for Cooperation and Development. 2008. OECD Benchmark Definition of Foreign Direct Investment. 4th ed. Paris: Organisation for Cooperation and Development.

Sachwald, F. 2005. 'Impact of Changing Production Location on Foreign Direct Investment.' Tokyo Club Foundation for Global Studies, Tokyo. Slaughter, M. J. 2002. 'Skill Upgrading in Developing Countries: Has Foreign Direct Investment Played a Role?' oecD Development Centre Working Paper 192. http://www.oecd.org/dev/1949135.pdf

—. 2004. 'Skill Upgrading in Developing Countries: Has Inward Foreign Direct Investment Played a Role?' In Labor and the Globalization of Production, edited by W. Milberg, 121-45. London: Palgrave Macmillan 
The Economist. 2013a. 'The Alibaba Phenomenon.' 23 March.

-2013b. 'Little to Fear But Fear Itself: Slowing Demand for Raw Materials Will Not Derail African Economies.' 21 September.

UNCTAD. 2000. World Investment Report 2000. Geneva: UNCTAD. . 2010. World Investment Report 2010. Geneva: UnCTAD.

- 2013. World Investment Report 2013. Geneva: UnCTAD.

Vale Columbia Center on Sustainable International Investment. 2013. 'Background Paper for the Eighth Columbia International Investment Conference on Investment Incentives: The Good, the Bad and the Ugly' https://doi.org/10.7916/D8C82JVS

\section{This paper is published under the terms of the Attribution-}

NonCommercial-NoDerivatives 4.o International (CC B Y-NC-ND 4.0)

License (http://creativecommons.org/licenses/by-nc-nd/4.o/). 


\title{
Abstracts in Slovene
}

\author{
Ali je zdravstveno varstvo potreba ali luksuzna dobrina? \\ Analiza panelnih podatkov na primeru držav članic \\ Zdravstvene mreže Jugovzhodne Evrope \\ Saša Obradović in Nemanja Lojanica
}

Glavni cilj tega prispevka je proučiti potencialno povezavo med gospodarsko rastjo in izdatki za zdravstvo $\mathrm{v}$ državah članicah Zdravstvene mreže Jugovzhodne Evrope v obdobju 1995-2014 z uporabo panelne ekonometrije. Pristop testiranja panelne kointegracije in vektorski model korekcije napak se uporabljata za raziskovanje dolgoročne in kratkoročne vzročne povezave med gospodarsko rastjo, izdatki za zdravstvo in pričakovano življenjsko dobo (trivariatni model). Empirični rezultati kažejo dolgoročno razmerje med opazovanimi spremenljivkami. Potrjeno je, da je zdravje dolgoročno luksuzna dobrina, kratkoročno pa potreba. Ob koncu je potrebno opozorilo, da bi morala biti gospodarska politika $\mathrm{v}$ teh državah usmerjena $\mathrm{v}$ ciljno povečanje izdatkov za zdravstveno varstvo $\mathrm{z}$ namenom povečanja splošne gospodarske dejavnosti. Tudi ekonomska politika bi morala biti usmerjena v ustrezno kombinacijo javnega in zasebnega financiranja $\mathrm{v}$ zdravstvu.

Ključne besede: izdatki za zdravstvo, gospodarska rast, zdravstvena mreža Jugovzhodne Evrope, panelna kointegracija, panel

Klasifikacija JEL: C23, H51, I10, I15

Managing Global Transitions 16 (3): 195-214

Odkrivanje kitajskih proizvodnih strategij za vzpodbujanje odnosa in namere: vključevanje inovacij, države porekla in znanja

Ramadania, Rianti Ardana Reswari in Endang Dhamayantie

Globalizacija širi možnosti izbire s pomočjo tehnologije, ki zagotavlja dovolj različnih informacij. Podjetja se tako na domači, kot na mednarodni ravni soočajo s konkurenco, ki je bolj intenzivna kot v obdobju pred globalizacijo. Kitajske blagovne znamke so v tujini vse bolj priljubljene in si prizadevajo tekmovati $\mathrm{z}$ drugimi svetovnimi blagovnimi znamkami. Globalni potrošniki nenehno iščejo najnovejše proizvode z najnižjo ceno na trgu. To iskanje usmerja znanje in pozornost na kitajske blagovne znamke. Namen te raziskave je raziskati vpliv novih izdelkov, države izvora in poznavanja izdelkov na nakupno namero glede na blagovno znamko. Za pridobitev podatkov so bili stotim anketirancem izročeni vprašalniki zaprtega tipa. Podatki so bili nato preračunani 
z uporabo Smart pls 3.2.7. Rezultati so pokazali, da se mora podjetje da bi ustvarilo ugodnejši odnos do blagovne znamke - osredotočiti na prizadevanja za ustvarjanje spomina kupcev glede specifikacij izdelkov. Ključne besede: inovativnost izdelkov, država porekla, poznavanje izdelkov, odnos do blagovne znamke, nakupni namen

Klasifikacija JEL: M3, O3

Managing Global Transitions 16 (3): 215-234

\section{Makroekonomske posledice depreciacije menjalnih tečajev: nigerijska izkušnja Ekundayo P. Mesagan, Olorunfemi Y. Alimi in Ismaila A. Yusuf}

Ta študija preučuje makroekonomske posledice depreciacije menjalnega tečaja v Nigeriji. Za podatke, ki zajemajo obdobje 1970-2015, je uporabljen kointegracijski pristop za testiranje avtoregresivnih porazdeljenih zamikov. Empirični rezultati potrjujejo, da depreciacija naira pozitivno in opazno vpliva na vse kazalnike makroekonomske uspešnosti, razen na proizvodnjo na prebivalca, ki je zanemarljiva. To pomeni, da depreciacija naira vzpodbuja trgovinsko bilanco, nestabilnost cen in povečuje obrestno mero. Depreciacija valute torej ne koristi gospodarstvu države. Poleg tega študija potrjuje, da obstaja dolgoročna povezava med depreciacijo menjalnih tečajev in makroekonomskimi rezultati $\mathrm{v}$ Nigeriji. Trgovinska in izvozna diverzifikacija sta potrebni za ohranitev dobičkov, povezanih z gibanji menjalnih tečajev in blaženje njihovih negativnih učinkov na gospodarstvo.

Ključne besede: depreciacija valute, proizvodnja, stopnja inflacije, obrestna mera, trgovinska bilanca

Klasifikacija JEL: B22, E31, E43, F31, O4O

Managing Global Transitions 16 (3): 235-258

\section{Različni načini, na katere aktivni državljani rešujejo okoljska vprašanja: študije primerov iz Madžarske Adrienn Reisinger in Katalin Bándy}

Prispevek prikazuje, kako lahko aktivni državljani rešujejo okoljska vprašanja s sodelovanjem $\mathrm{v}$ lokalnih ali nacionalnih programih ali pri dogodkih. Po eni strani je namen prispevka predstaviti teorijo družbene vključenosti aktivnih državljanov s poudarkom na okoljskih vprašanjih. Po drugi strani pa gre za poskus predstaviti temo s pomočjo treh dobrih primerov iz Madžarske, ki temeljijo na drugotnih informacijah in intervjujih. Prvi je program šolskih vrtov; v Szentgotthárdu gre za vprašanje 
načrtovane sežigalnice, ki je bila pred nekaj leti prepovedana zaradi dejavnosti lokalnih civilnih organizacij. Tretji program, t.i. Te Szedd (program zbiranja smeti v organizirani kampanji na Madžarskem), pa kaže pristop od zgoraj navzdol, ki ga upravljajo lokalni prebivalci. Rezultati kažejo, da so državljani lahko dejavni pri oblikovanju okoljskih vprašanj, vendar se zdi najpomembneje to, da se za tovrstna vprašanja tudi osebno zavzamejo.

Ključne besede: aktivni državljani, družbena vključenost, okoljska vprašanja, upravljanje, dobri primeri

Klasifikacija JEL: R11, L31

Managing Global Transitions 16 (3): 259-277

\section{Sodobni trendi v kitajskih neposrednih tujih naložbah v Afriki: pristop na temelju lastništva, lokacije in internalizacije Henri Bezuidenhout in Ewert P. J. Kleynhans}

Ta študija ocenjuje razlike, ki jih različne vrste neposrednih tujih naložb Kitajske v Afriki ponujajo, kot kažejo podatki, z uporabo pristopa 'lastništva, lokacije in internalizacije.' Kitajske neposredne tuje naložbe so analizirane s pomočjo primerjav z izvornimi državami, sektorskih primerjav in raziskav kitajskih praks s področja neposrednih tujih naložb. Tehnike vizualizacije podatkov in analize kažejo podobnosti in razlike med kitajskimi in drugimi vlagatelji v Afriki. Te alternativne metode temeljijo na naravi razpoložljivih podatkov in statističnih možnostih, ki iz tega izhajajo. Študija je pomembna, saj razkriva razpoložljive podatke in primerja teorije. Kitajskih neposrednih tujih naložb se drži slab sloves prirejanja podatkov; študija te predpostavke količinsko opredeli in preveri. Rezultati kažejo, da Kitajska sledi naložbenim vzorcem drugih vlagateljev, čeprav je močno usmerjena proti naftnemu, premogovnemu in plinskemu sektorju ter sektorjem drugih virov. Kitajska sicer najpogosteje vlaga $v$ srednjo rast, raznolika gospodarstva, predvsem v Nigeriji in Egiptu - v Etiopiji prevladujejo naložbe v komunikacije, v Kamerunu naložbe $\mathrm{v}$ kemikalije, $\mathrm{v}$ Angoli naložbe $\mathrm{v}$ nepremičnine, ki presegajo naložbe v premog, nafto in plin - ter v Južni Afriki in Tanzaniji, ki imata bolj enakomerno razporeditev med sektorji v primerjavi s preostalim delom celine.

Ključne besede: neposredne tuje naložbe, Afrika, Kitajska, pristop na temelju lastništva, lokacije in internalizacije, eklektična paradigma

Klasifikacija JEL: F2O, F21, F23

Managing Global Transitions 16 (3): 279-300 